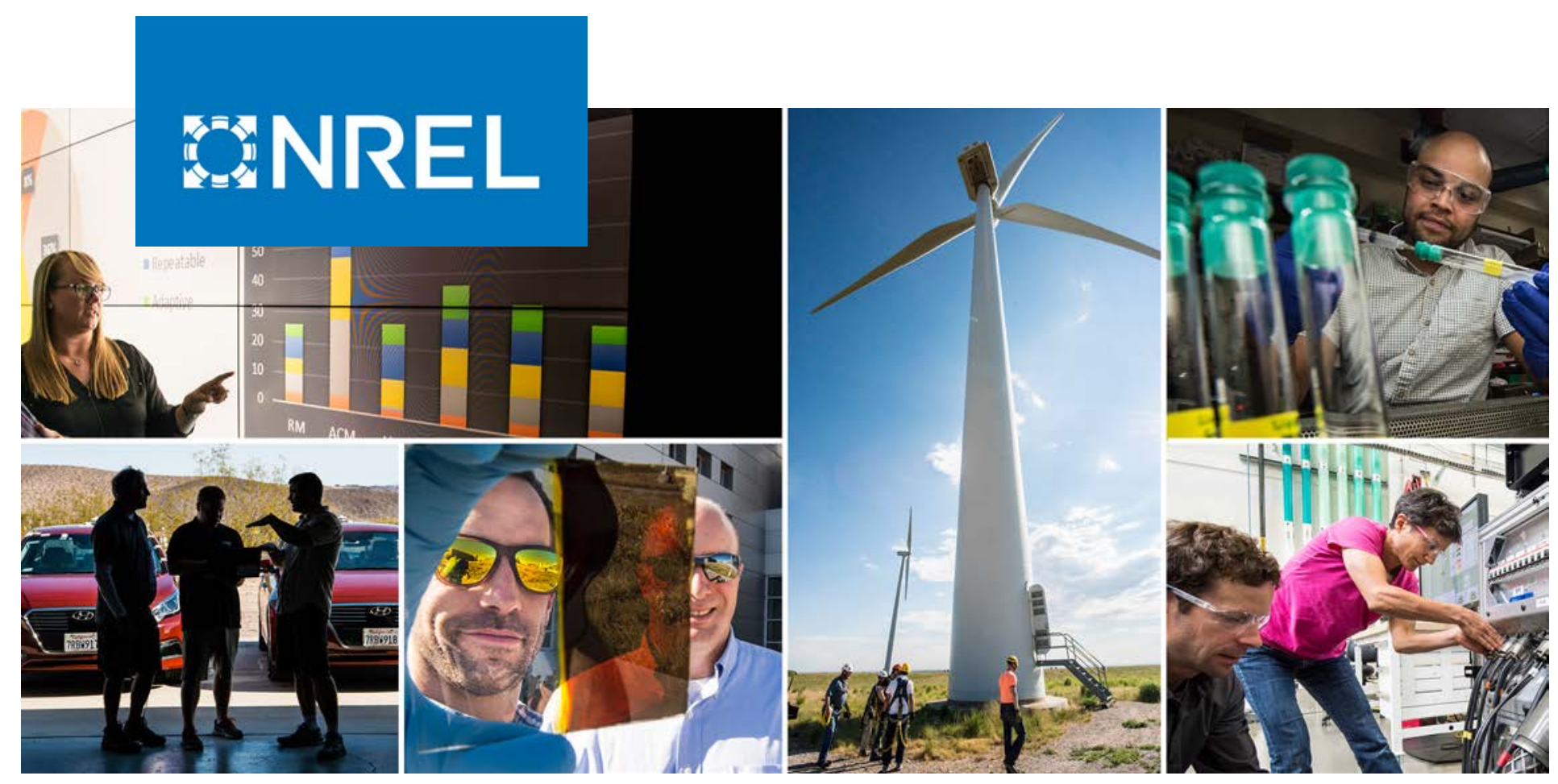

\title{
Expanding the Photovoltaic Supply Chain in the United States: Opportunities and Challenges
}

Brittany L. Smith and Robert Margolis

NREL is a national laboratory of the U.S. Department of Energy Office of Energy Efficiency \& Renewable Energy

Operated by the Alliance for Sustainable Energy, LLC

This report is available at no cost from the National Renewable Energy Laboratory (NREL) at www.nrel.gov/publications.
Technical Report

NREL/TP-6A20-73363

July 2019 


\title{
EAREL
}

\section{Expanding the Photovoltaic Supply Chain in the United States: Opportunities and Challenges}

\author{
Brittany L. Smith and Robert Margolis
}

\section{Suggested Citation}

Smith, Brittany L., and Robert Margolis. (2019). Expanding the Photovoltaic Supply Chain in the United States: Opportunities and Challenges. Golden, CO: National Renewable Energy Laboratory. NREL/TP-6A20-73363. https://www.nrel.gov/docs/fy19osti/73363.pdf.

NREL is a national laboratory of the U.S. Department of Energy Office of Energy Efficiency \& Renewable Energy Operated by the Alliance for Sustainable Energy, LLC

This report is available at no cost from the National Renewable Energy Laboratory (NREL) at www.nrel.gov/publications.

Contract No. DE-AC36-08GO28308
Technical Report NREL/TP-6A20-73363 July 2019

National Renewable Energy Laboratory 15013 Denver West Parkway Golden, CO 80401 303-275-3000 • www.nrel.gov 


\section{NOTICE}

This work was authored by the National Renewable Energy Laboratory, operated by Alliance for Sustainable Energy, LLC, for the U.S. Department of Energy (DOE) under Contract No. DE-AC3608G028308. Funding provided by the U.S. Department of Energy Office of Energy Efficiency and Renewable Energy Solar Energy Technologies Office. The views expressed herein do not necessarily represent the views of the DOE or the U.S. Government.

This report is available at no cost from the National

Renewable Energy Laboratory (NREL) at

www.nrel.gov/publications.

U.S. Department of Energy (DOE) reports produced

after 1991 and a growing number of pre-1991

documents are available

free via www.OSTI.gov.

Cover Photos by Dennis Schroeder: (clockwise, left to right) NREL 51934, NREL 45897, NREL 42160, NREL 45891, NREL 48097, NREL 46526.

NREL prints on paper that contains recycled content. 


\section{Acknowledgments}

This work was funded by the U.S. Department of Energy's Solar Energy Technologies Office. We would like to acknowledge the following individuals for their helpful comments, corrections, and contributions: David Feldman (NREL) for review and production data, Michael Woodhouse (NREL) for contribution to the CapEx analysis, Tim Remo (NREL) for contribution to historical module performance analysis, Billy Roberts (NREL) for supply chain maps, Jarett Zuboy (Independent Contractor) for technical editing, and reviewers Jill-Engel-Cox (NREL), Debra Sandor (NREL), Charlie Gay (DOE), Stephen Capanna (DOE), Benjamin King (DOE), Brian Walker (DOE), Beryl Weinshenker (All Correct Solar), Ian Marius Peters (MIT), Sergio Castellanos (UC Berkeley), Doug Arent (NREL), Dan Bilello (NREL), Gian Porro (NREL), and Gary Schmitz (NREL) for their valuable feedback. 


\section{List of Acronyms}

$3 \mathrm{~N}$

$9 \mathrm{~N}$

$11 \mathrm{~N}$

BOS

CapEx

CdTe

CIGS

c-Si

CSUN

$\mathrm{Cz}$

DC

DS

EIA

EPC

EVA

GW

HEVA

HTS

$\mathrm{kg}$

LDPE

LEVA

MEVA

mg-Si

MT

PERC

PII

PV

PVF

ROW

UPS

USD

USITC

VAM

W

Wac

$\mathrm{Wdc}$
99.9\% pure

$99.9999999 \%$ pure

$99.999999999 \%$ pure

balance of system

capital expenditures

cadmium telluride

copper indium gallium (di)selenide

crystalline silicon

China Sunergy

Czochralski

direct current

directional solidification

U.S. Energy Information Administration

engineering, procurement, and construction

ethylene vinyl acetate

gigawatts

high-density EVA

Harmonized Tariff Schedule

kilogram

low-density polyethylene

low-density EVA

medium-density EVA

metallurgical-grade silicon

metric tons

passivated emitter and rear cell

permitting, inspection, and interconnection

photovoltaic

polyvinyl fluoride

rest of world

uninterruptible power supplies

U.S. dollars

U.S. International Trade Commission

vinyl acetate monomers

watts

watts alternating current

watts direct current 


\section{Executive Summary}

Growth in U.S. manufacturing of solar-grade polysilicon, photovoltaic (PV) cells, and PV modules has not kept pace with global growth in these industries, and in some cases has even decreased. As a result, the United States has lost approximately $80 \%$ of its global market share in these industries over the past decade. However, projections of strong PV demand growth continuing in the United States and globally_along with significant announced U.S. cell and module plant expansions - suggest that PV could have important near-term impacts on related U.S. manufacturing sectors.

This report primarily considers the infrastructure availability in the United States to meet demand for industries upstream of PV manufacturing if all U.S. PV installations were manufactured domestically from domestically sourced materials and components. It does not evaluate economic factors such as cost-competitiveness with other countries, policy incentives, shipping costs, and so forth, which are important factors to evaluate but are outside the scope of this work. Our goal is to delineate the infrastructure challenges and opportunities that upstream U.S. manufacturing sectors could encounter if the U.S. PV manufacturing sector grows. This analysis could be used in future discussions of the feasibility of creating a domestic PV supply chain that relies on domestic sourcing for upstream materials.

Our analysis considers both crystalline-silicon (c-Si) and thin-film PV, but it focuses on c-Si because c-Si represented approximately $97 \%$ of the 2017 U.S. PV market. We first analyze the polysilicon-to-module supply chain of c-Si PV technology. U.S. polysilicon production in 2017 was roughly equivalent to the amount needed for 2017 U.S. PV demand, even while operating below $50 \%$ capacity. However, there are currently no U.S. producers of silicon ingots or wafers for solar applications, so we assume that U.S. polysilicon is either used for electronic applications or exported. As such, we assume that the 260 MW of U.S. c-Si PV cell production in 2017 relied entirely on imported wafers. Imports supplied about $60 \%$ of the 2017 U.S. market for c-Si cells and $92 \%$ of the market for PV modules including thin-film PV. Additionally, roughly $4 \%$ of c-Si cells and 18\% of all PV modules were stockpiled in 2017 owing to anticipated policy uncertainty.

However, during 2017 through mid-2019, U.S. manufacturers announced plans to add a total of 1.6 GW of c-Si cell production capacity, $6.2 \mathrm{GW}$ of c-Si module capacity, and $1.2 \mathrm{GW}$ of thinfilm module capacity. If these announced expansions are built, they would represent a tenfold increase in U.S. c-Si cell capacity and a threefold increase in U.S. module (c-Si plus thin-film) capacity, compared with the existing production capacities from the beginning of 2017. Such an increase in domestic PV production could significantly impact the U.S. supply chains for input materials.

We analyze a selection of upstream products and materials currently in the U.S. PV supply chain and examine how they might be affected under different scenarios of PV market growth. We focus on the most expensive primary materials and components as depicted in Figure ES-1, excluding c-Si cells which are detailed in Woodhouse et al. (2019). These include steel racking, aluminum frames and racking, inverters, flat glass, encapsulants, and backsheets. Aluminum and steel production and consumption data are sourced from the U.S. Geological Survey and GreenTech Media, while inverter, glass, encapsulant, and backsheet data are drawn from 
specialized market reports. Trade data for all products are sourced from the U.S. International Trade Commission, with the exception of backsheets, for which data are from the IHS Markit Connect database.

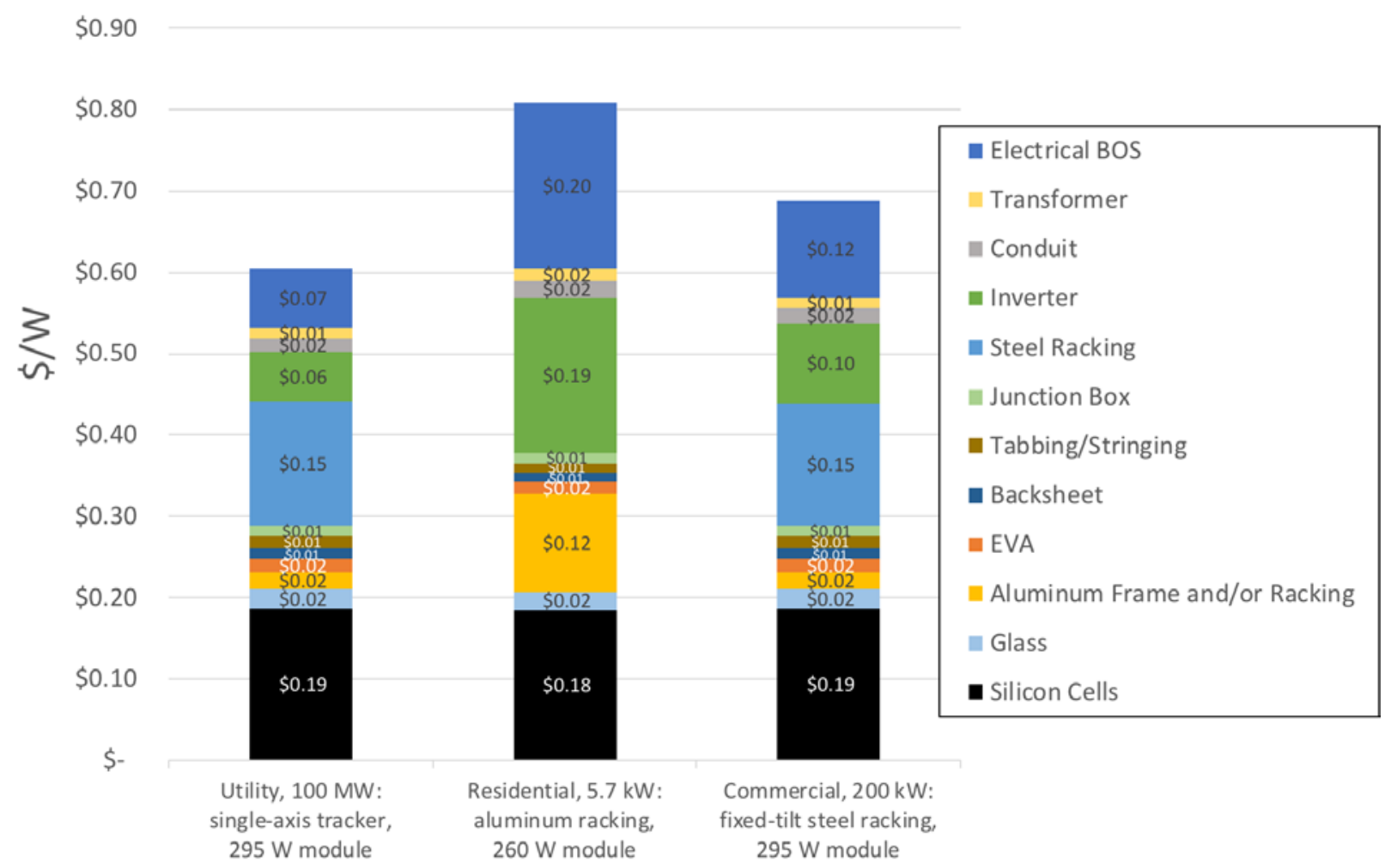

Figure ES-1. Material/component cost contributions of utility-scale, residential, and commercial PV systems, 2017 (does not include installation labor, overhead expenses, sales tax, or profit margins)

Steel. In 2017, the total U.S. steel market relied primarily (70\%) on domestically produced steel. In 2016, the United States produced a quantity of steel PV racking roughly equal to the amount used by all ground-mounted PV installed that year, suggesting that the United States could have met its own demand for steel PV racking production, although it is uncertain what fraction of the steel used to construct the racking was from domestic sources. Because the amount of steel used in U.S. PV installations in 2017 represented less than 1\% of total U.S. steel consumption, and U.S. steel production has been operating below $80 \%$ capacity utilization, growth in PV installations could have modest benefits for local steel production without encountering supply constraints.

Aluminum. In 2017, domestic aluminum production supplied $28 \%$ of the total U.S. aluminum market, even though U.S. primary aluminum manufacturing capacity was at less than $50 \%$ utilization. In 2016, the United States produced a quantity of aluminum PV racking roughly equal to the amount needed for its rooftop PV installations, suggesting that the United States can meet its own demand for aluminum PV racking, even though the domestically produced racking in 2016 was likely constructed by extruding imported aluminum. Because the United States relies significantly on imported PV modules, these typically arrive assembled with a foreignsourced aluminum frame. The total amount of aluminum contained in U.S. PV installations in 2017 (including frames) represented less than $2 \%$ of total U.S. aluminum consumption. Thus, if 
domestic aluminum becomes cost-competitive with foreign aluminum, growth in PV installations or PV module assembly could help occupy idle primary aluminum production capacity without encountering supply constraints.

Inverters. In 2017, the total U.S. market for all inverter applications (including PV) relied primarily (71\%) on domestic inverter production. However, 2017 U.S. production of PV inverters was roughly equal to $40 \%$ of PV inverters installed domestically that year, where PV inverters account for approximately $15 \%$ of the total U.S. inverter market. Although the domestic share of PV inverters has declined significantly over the past several years, concerns have begun to emerge regarding grid cybersecurity when relying on foreign-produced power electronics. If this concern persists, it could stimulate a return to higher domestic PV inverter production by trusted domestic suppliers.

Flat glass. In 2017, the total U.S. flat glass market relied primarily (56\%) on domestic production. Because glass is fragile and dense and therefore expensive to ship, growth in U.S. PV module production could represent an opportunity for growth in the U.S. flat glass industry. In 2017, U.S. PV module production represented less than $1 \%$ of total U.S. flat glass consumption. However, given the current demand in the flat glass market as well as the time and capital required to construct new lines, accelerated growth in U.S. PV module manufacturing could result in flat glass supply-demand imbalances, particularly if glass-glass thin-film or bifacial modules gain in market share.

Encapsulants. We assume EVA is the most common PV encapsulant material. The United States was a net exporter of EVA polymer in 2017, and it has a global advantage in production of EVA and other low-density polyethylene (LDPE) owing to the abundance of inexpensive shalegas feedstocks. PV module production in the United States in 2017 represented less than 1\% of the total amount of U.S. EVA consumption. The total amount of EVA contained in 2017 U.S. PV installations represented 14\% of total 2017 U.S. EVA consumption in all sectors, suggesting that growth of U.S. PV module manufacturing could become a major driver of domestic EVA production. Because most LDPE reactors can be easily modified to produce EVA, the United States could expand production to meet growth in domestic and global PV demand for EVA.

Backsheets. We analyze Tedlar as a primary material in PV backsheets, because the United States is the primary global supplier of Tedlar (a polyvinyl fluoride [PVF] film extruded from PVF resin). In 2017, 25\% $-30 \%$ of PV backsheets used at least one sheet of Tedlar. We estimate that up to $96 \%$ of PVF resin is consumed by the PV industry and that all the Tedlar contained in U.S. PV installations was produced domestically. Given the uncertain longevity of alternative backsheet materials and the potential of transparent Tedlar replacing back cover glass in bifacial modules (which are expected to gain market share), Tedlar demand may increase further as global PV installations grow, prompting new capacity additions.

We quantify the potential impact of PV demand growth on the markets for each of these components by considering two scenarios - one with domestic PV demand doubling, and another with demand increasing tenfold - under two different assumptions: either all demand is met by domestic production, or the percentage of demand met by domestic production is held constant at 2017 levels. The results from this analysis are summarized in Figure ES-2. Demand from U.S. $\mathrm{PV}$ installations in 2017 would have been less than $20 \%$ of total U.S. production for any given 
component, even if all 2017 U.S. PV installations had been supplied via domestically sourced components. If all demand is met by domestic production in the $2 \mathrm{x}$ scenario, U.S. PV demand would be a significant driver in the markets for EVA (PV would account for 20\% of total 2017 production) and inverters (40\%). In the 10x scenario when all PV demand is met by domestic production, the markets would be heavily affected for flat glass (U.S. PV would account for $60 \%$ of total 2017 production), aluminum (40\%), Tedlar (100\%), EVA (110\%), and inverters (180\%). In the cases explored here, only steel would not be supply constrained. Even under the most aggressive scenario (10x production with all demand met domestically), steel demand increases to only $8 \%$ of 2017 production levels.

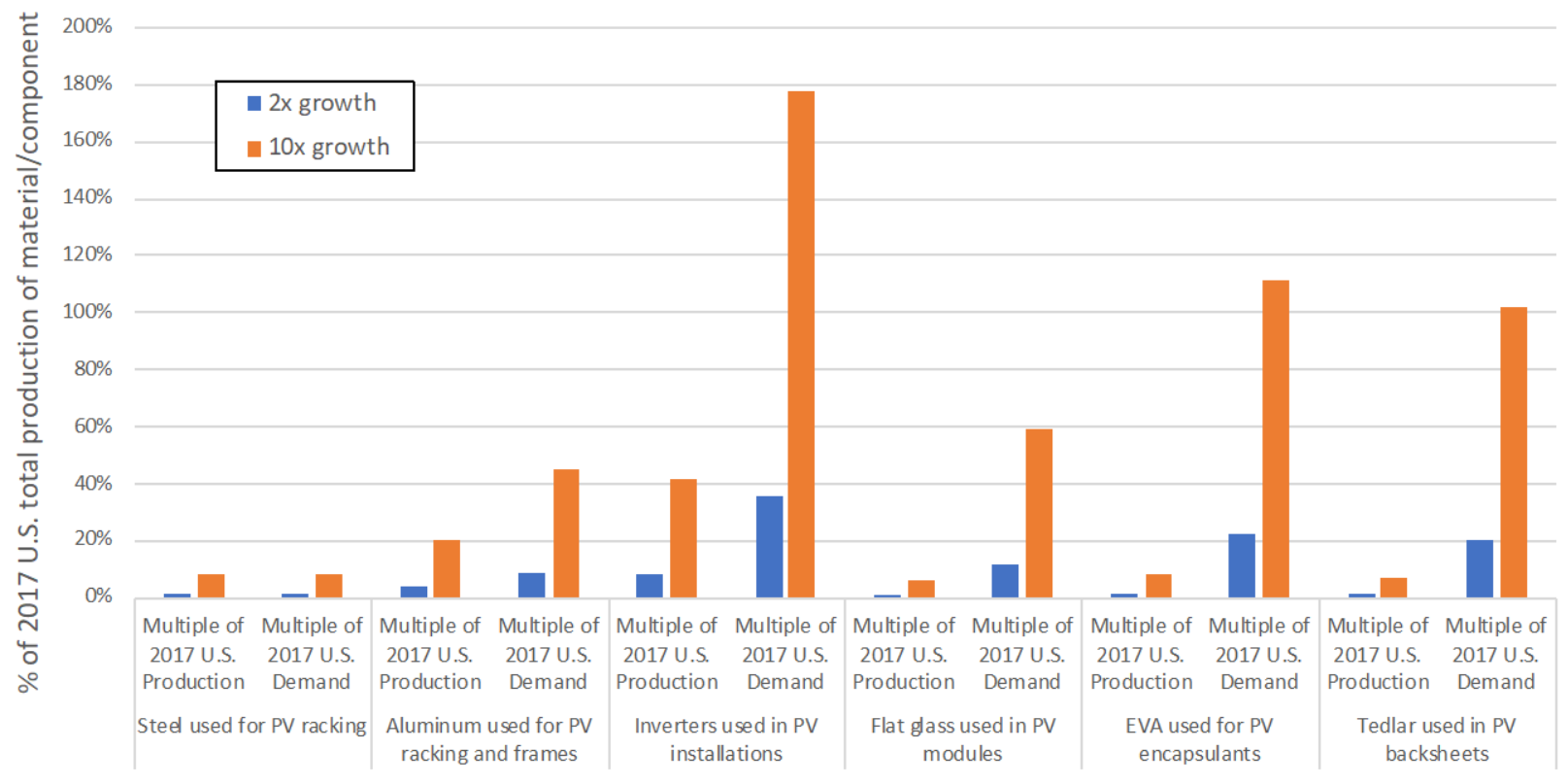

Figure ES-2. Growth scenarios for U.S. demand of PV materials/components compared to 2017 U.S. production of each material/component for all applications including PV

Ultimately, the growth of the U.S. PV industry could represent significant potential for growth in upstream industries. The United States is already an exporter of PV components such as EVA and Tedlar. When looking across key PV components and materials, the United States does not rely heavily on imports of flat glass and steel. If U.S. PV module manufacturing increases, it might rely more on domestic sources for a range of components and materials. The United States currently relies mostly on imports of aluminum and PV inverters, but it still has significant domestic production capacity that could be increased with relative ease if PV demand for domestic components increases. Specifically, inverters and EVA have existing manufacturing capacity that would be relatively easy to adapt and scale (less capital and time intensive than other industries). Flat glass and Tedlar, in contrast, would require larger investments and more time to expand production, but could serve as a potential catalyst for industry growth if PV demand increases. In addition, because the United States has significantly underutilized steel and aluminum production capacity, it could be feasible to move towards extruding racking and module frames from domestic sources if they can be cost-competitive with foreign sources. 


\section{Table of Contents}

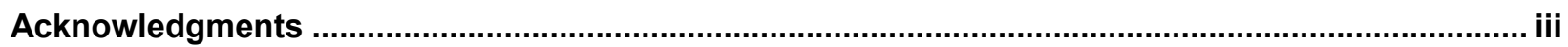

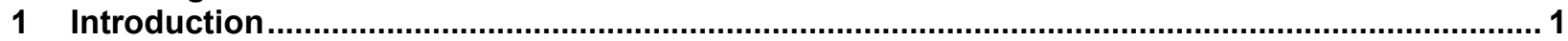

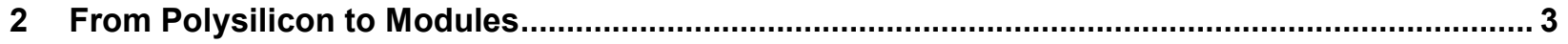

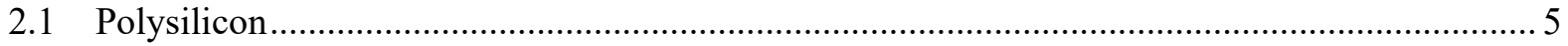

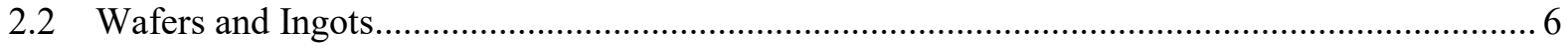

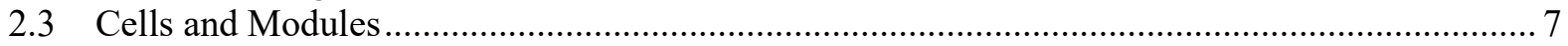

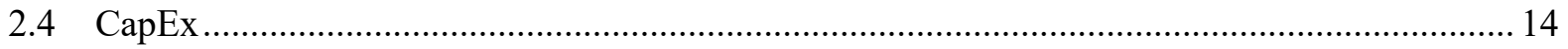

3 Upstream Materials and Components in the PV Supply Chain .......................................... 16

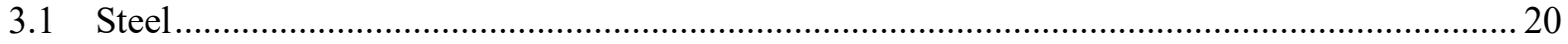

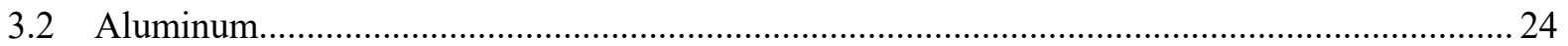

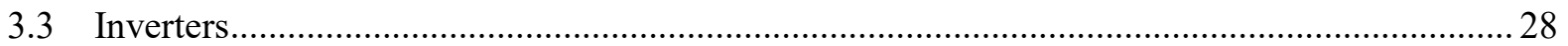

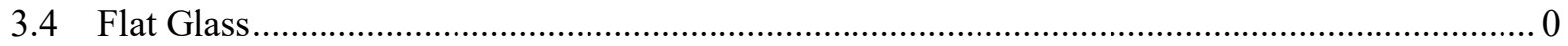

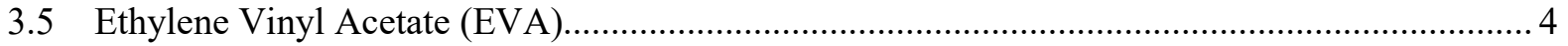

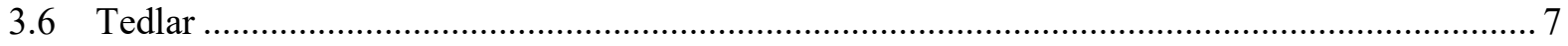

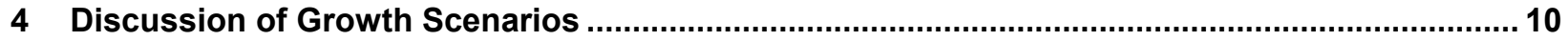

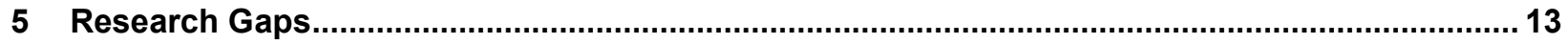

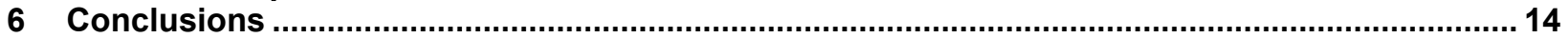

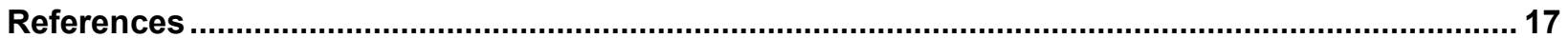

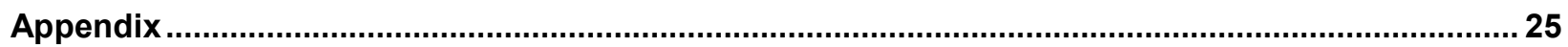

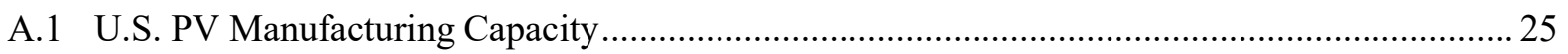

A.2 Data for PV System Cost and Mass Breakdown ................................................................... 27 


\section{List of Figures}

Figure 1. Annual historical and projected installations of PV systems, globally from 2011-2022 ............. 1

Figure 2. Global PV module shipments by select country/region from 1997-2017 …........................... 2

Figure 3. Cost per watt for c-Si modules and cost per kg of polysilicon, 2010-2018 (BNEF 2018) .......... 3

Figure 4. Module efficiency for ci-Si PV, 2007-2017 (BNEF 2018) .................................................... 4

Figure 5. National Renewable Energy Laboratory PV system cost benchmark summary for residential, commercial, and utility-scale systems, 2010-2018 (Fu, Margolis, and Feldman 2018).......... 4

Figure 6. Schematic of the c-Si portion of the PV supply chain........................................................ 5

Figure 7. U.S. solar-grade polysilicon production and capacity from 2010-2017 (GTM Research and

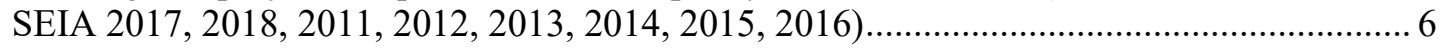

Figure 8. U.S. silicon trade flows in 2017 in MT ............................................................................. 6

Figure 9. U.S. cell and module production and capacity from 2010-2017 (Feldman, Margolis, and

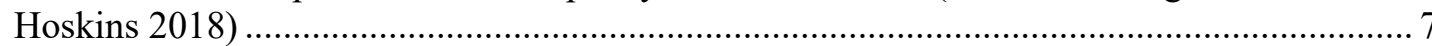

Figure 10. U.S. PV cell trade flows in 2017, based on HTS code 8541.40.6030 (USITC 2017) ............... 8

Figure 11. U.S. PV module trade flows in 2017 (including c-Si and thin film), based on HTS code

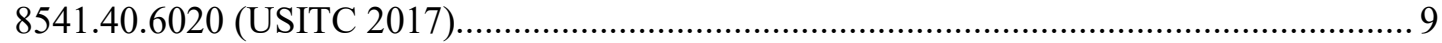

Figure 12. U.S. wafer, cell, module, and polysilicon production facilities in operation, mid-2017 .......... 12

Figure 13. Planned additions of PV cell and module production capacity, announced in 2017-2019 (note: SoloPower facility closed permanently, SunPower and Silfab locations acquired from

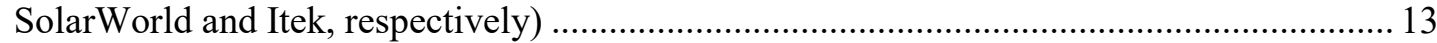

Figure 14. Historical CapEx for PV component production at $>100 \mathrm{MW}$ capacity greenfield facilities ... 16 Figure 15. Annual historical and projected installations of U.S. PV, 2010-2021 (BNEF 2018), (Goldman Sachs 2018), (GTM Research and SEIA 2018), (IHS 2018), (Deutsche Bank AG 2018).... 18

Figure 16. Material/component contributions of utility-scale, commercial, and residential PV systems to cost (left column) and mass (right column) ....................................................................... 20

Figure 17. Global steel production in 2017, constructed from data in U.S. Geological Survey (2018) .... 22

Figure 18. U.S. steel capacity in 2017, estimated from data in U.S. Geological Survey (2018) and AIM Market Research (2010).

6
8 (1)

2




\section{List of Tables}

Table 1. Assumptions Used in First Half of 2018 CapEx Benchmark, for c-Si PV Supply Chain ............ 15

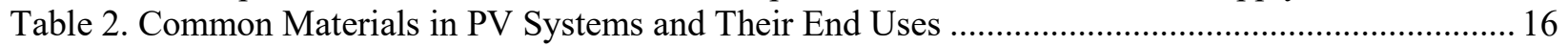

Table 3. U.S. PV System Installations by Sector and Racking Type, 2017 ........................................... 17

Table 4. Global and Domestic Steel Consumption Compared to PV Steel Consumption in 2017.............23

Table 5. U.S. Ground-Mount Racking Shipments by Company in 2016, Constructed from Weinshenker (2017)

Table 6. Global PV Tracker Shipments by Company in 2017, constructed from Moskowitz (2018)....... 24

Table 7. Global and Domestic Aluminum Consumption Compared to PV Aluminum Consumption in 2017.

Table 8. U.S. Rooftop Racking Shipments in 2016, Constructed from Weinshenker (2017) ................... 28

Table 9. Select Global PV Inverter Manufacturers, Constructed from Solar Power World (2019) ........... 29

Table 10. Global and Domestic Inverter Consumption in 2017 Compared to PV Inverter Consumption . 30

Table 11. Largest Suppliers of U.S. PV Inverters in 2017, Constructed from Moskowitz (2017) ............... 0

Table 12. Largest Suppliers of Global PV Inverters in 2017, Constructed from Moskowitz (2017) ........... 0

Table 13. Global and Domestic Flat Glass Consumption in 2017 Compared to Solar-Grade Flat Glass

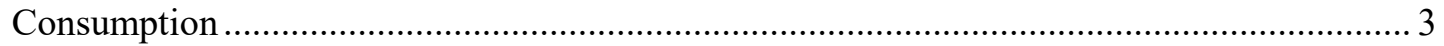

Table 14. Global and Domestic EVA Consumption in 2017 Compared to PV EVA Consumption ............ 7

Table 15. Global and Domestic PVF Resin Consumption in 2017 Compared to PV PVF Resin

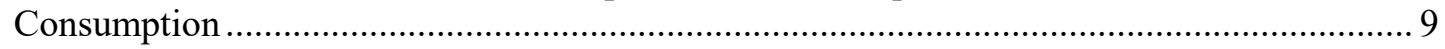

Table 16. U.S. PV Manufacturing Capacity in Q1 2017 and Announcements during 2017-2019 ........... 25

Table 17. Breakdown of 295-W PV Module Cost and Mass (260-W Module in Parentheses)................. 27

Table 18. Cost and Mass Breakdown of 100-MW Utility-Scale PV System: 295-W Modules and Steel

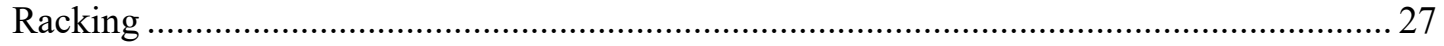

Table 19. Cost and Mass Breakdown of 200-kW Ground-Mount Commercial PV System: 295-W

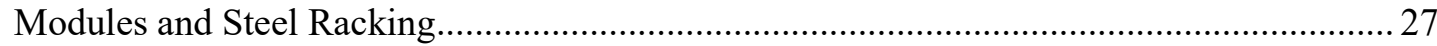

Table 20. Cost and Mass Breakdown of 200-kW Rooftop Commercial PV System: 295-W Modules and

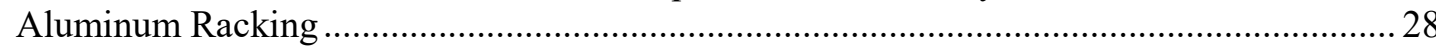

Table 21. Cost and Mass Breakdown of 5.7-kW Residential PV System: 260-W Modules and Aluminum

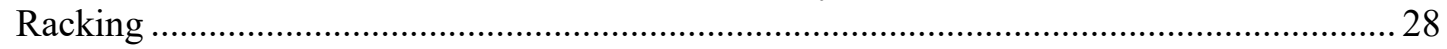




\section{Introduction}

Solar installations across the globe have been expanding at a rapid pace over the last decade, in both industrialized and developing countries. Figure 1 shows photovoltaic (PV) installations by region since 2011, along with projections through 2022. Global PV demand is projected to increase over the forecasted period, with the strongest growth coming from countries in the rest of world (ROW) region. The United States is projected to realize modest growth in the near term. However, projections for 10 years from now indicate the U.S. PV market could at least double, or even grow 10-fold in some scenarios (Jones-Albertus et al. 2018). Growth in the U.S. domestic market as well as diversifying global demand for PV create an opportunity for expanding the U.S. PV module manufacturing industry. Opportunity also exists for expanding the U.S. supply chain for PV components and materials including racking, encapsulants, backsheets, solar-grade glass, and inverters.

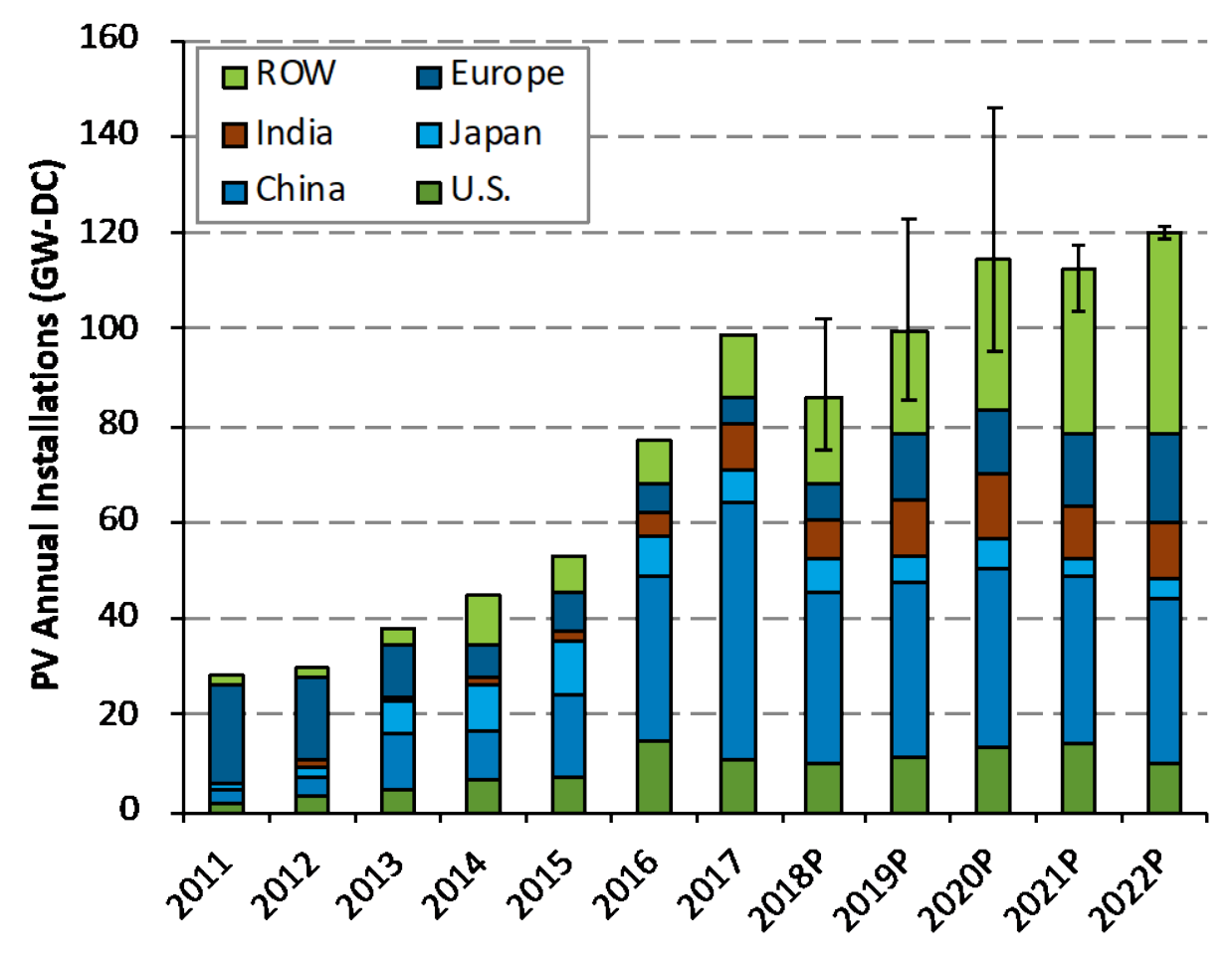

$\mathrm{DC}=$ direct current $\mathrm{P}=$ projection. Bar represents median projection. Error bars represent high and low projections. Sources: (BNEF 2018), (Cowen Inc. 2018), (Credit Suisse Group AG 2018), (Wood Mackenzie 2018), (Goldman Sachs 2018)

Figure 1. Annual historical and projected installations of PV systems, globally from 2011-2022

During the past couple decades, there has been a shift from domestic to overseas manufacturing with respect to the PV module supply chain (SPV Market Research 2017). The United States once was a significant producer of PV module components, including solar-grade polysilicon, silicon PV wafers, cells, and modules (SPV Market Research 2017, Sandor et al. 2018). As shown in Figure 2, the United States accounted for approximately $13 \%$ of global PV module shipments in 2004, but the U.S. share of module shipments dropped to approximately $0.5 \%$ in 2017. A similar pattern of declining U.S. market share in the context of rapid global growth has 
played out for PV cells, wafers, and polysilicon production. This loss has been attributed to Chinese government subsidies for PV manufacturing facilities and their access to low-cost debt and regional suppliers, which has since been further compounded by economies of scale (Goodrich, James, and Woodhouse 2011).

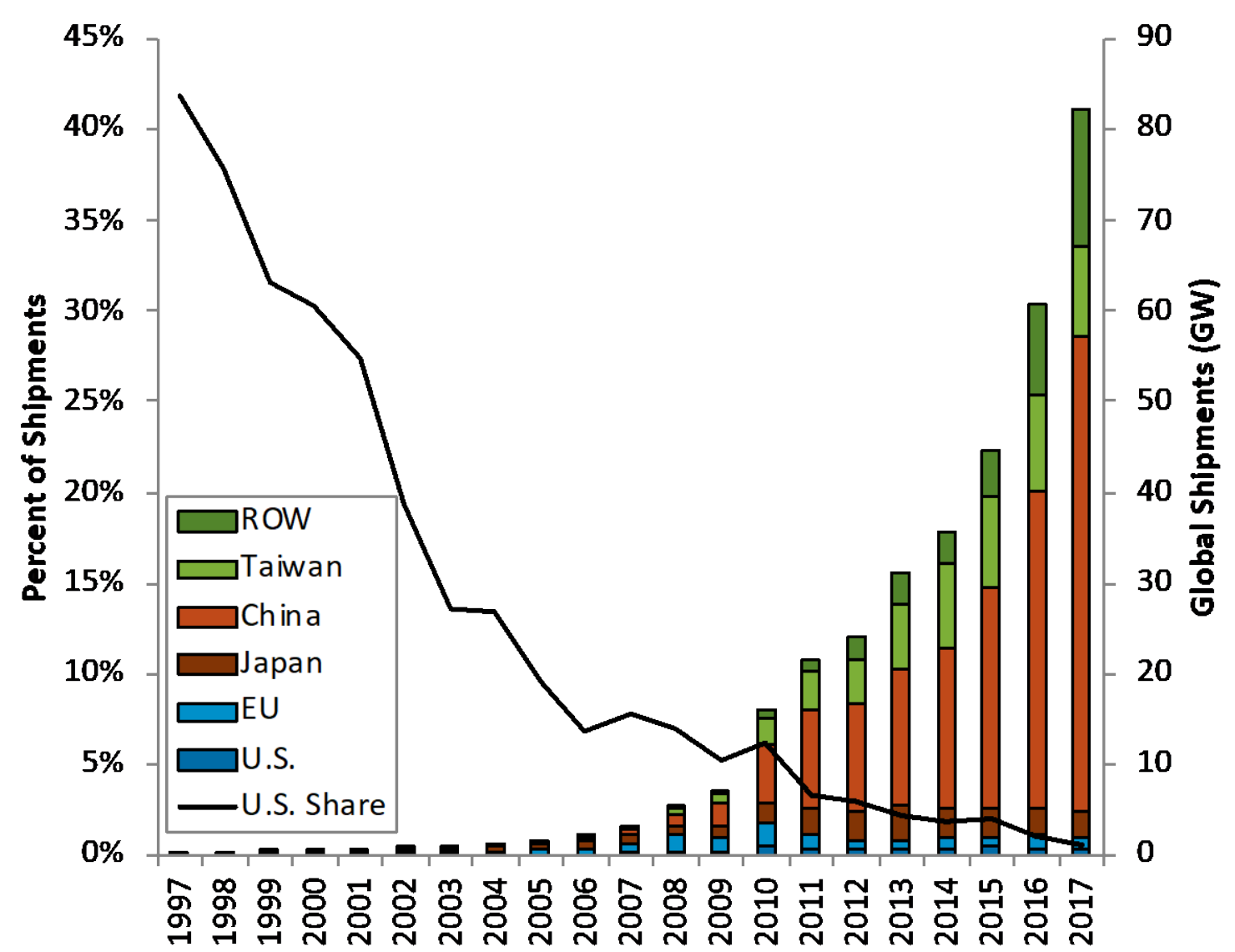

Figure 2. Global PV module shipments by select country/region from 1997-2017

In this report, we begin by examining the current U.S. silicon PV supply chains and drawing lessons from recent PV manufacturing trends while identifying opportunities for and potential challenges to realizing growth in the U.S. PV manufacturing sector. To provide context for the original contribution of this report, we also conducted a thorough literature review. Some national supply chain analysis frameworks have already been applied to Mexico, Iran, and Japan for the primary silicon PV supply chain segments of polysilicon production, wafer production, cell manufacturing, module manufacturing, and system installation (Castellanos et al. 2018, Tanaka et al. 2018, Dehghani, Jabalameli, and Jabbarzadeh 2018). The study pertaining to Mexico calculated minimum sustainable prices for polysilicon, ingots, wafers, cells, and modules depending on the state where production was located and estimated trade flows with China, the United States, and Brazil based on a number of tariff scenarios (Castellanos et al. 2018). The study involving Iran used an optimization model to determine which cities should contain largescale solar installations as well as polysilicon, wafer and ingot, cell, or module manufacturing (Dehghani, Jabalameli, and Jabbarzadeh 2018). The study concerning Japan evaluated the flow of cells, modules, and inverters through Japan in 2014 as well as PV installations in Japan, and it 
used these data to estimate the global distribution of value generated from both PV production and PV installations in Japan (Tanaka et al. 2018).

However, the main focus of this report is to examine manufacturing sectors upstream of PV systems by first identifying the most costly primary components in finished PV systems with the exception of polysilicon, wafers, and cells; the most expensive materials in polysilicon, wafers, and cells (silicon and silver) have been detailed elsewhere (Woodhouse et al. 2019, Sandor et al. 2018, Redlinger, Eggert, and Woodhouse 2016, Fu, James, and Woodhouse 2015). We identify the top six other costly components as steel, aluminum, inverters, flat glass, encapsulants (namely, ethylene vinyl acetate), and backsheets (this study focuses on Tedlar backsheets). Producing these components could provide new opportunities for domestic manufacturing, particularly in industries where the United States has existing manufacturing capacity, leadership, or other competitive advantages. Next, we examine opportunities and challenges related to expanding U.S. PV manufacturing under two possible demand-growth scenarios. Finally, we summarize the opportunities and challenges related to realizing growth across the U.S. PV supply chain going forward.

\section{From Polysilicon to Modules}

The PV industry has changed dramatically during the past decade. Crystalline silicon (c-Si) PV has continued to be the dominant technology, but the scale of production has increased, efficiencies of cells and modules have increased, and cost has declined rapidly. In 2011, c-Si cells made up around 85\% of the marketplace. In 2017, c-Si accounted for $96 \%$ of all PV shipments, followed by cadmium telluride (CdTe) at 3\% and copper indium gallium (di)selenide (CIGS) at 1\% (SPV Market Research 2017). As shown in Figure 3, multicrystalline c-Si module costs declined from roughly $\$ 2 / \mathrm{W}$ in 2010 to less than $\$ 0.50 / \mathrm{W}$ in 2018 , which represents a $75 \%$ decrease in cost. Contributions to the module cost reduction include declining polysilicon costs (also shown in Figure 3) and increasing module efficiency. For example, as shown in Figure 4, the typical efficiency of commercial multicrystalline c-Si modules increased from roughly $13 \%$ in 2007 to roughly $17 \%$ in 2017 . This translates into a roughly $30 \%$ increase in output from efficiency gains alone (holding all other factors constant) for the same amount of PV module area.

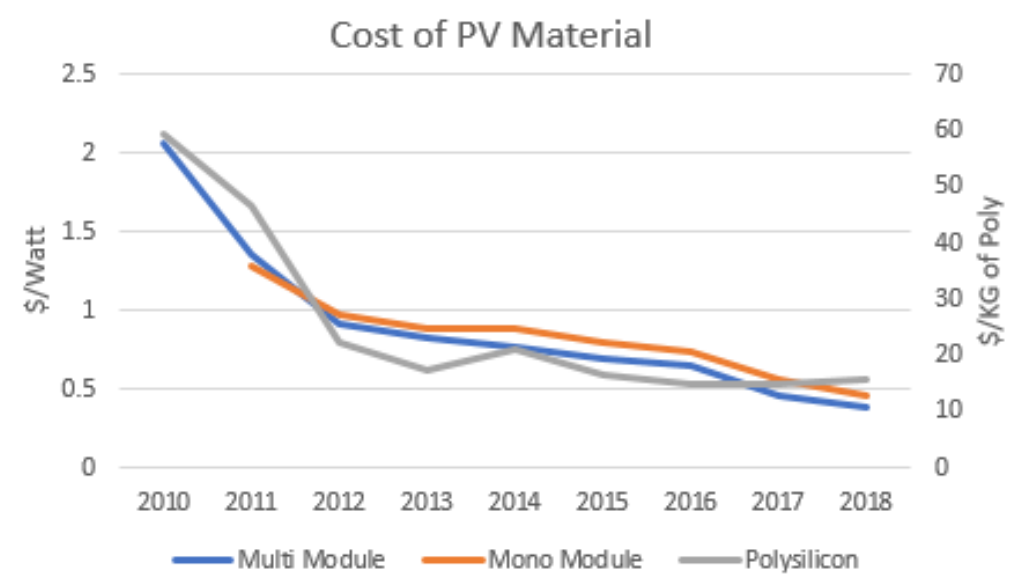

Figure 3. Cost per watt for c-Si modules and cost per kg of polysilicon, 2010-2018 (BNEF 2018) 


\section{Module Efficiency Trend}

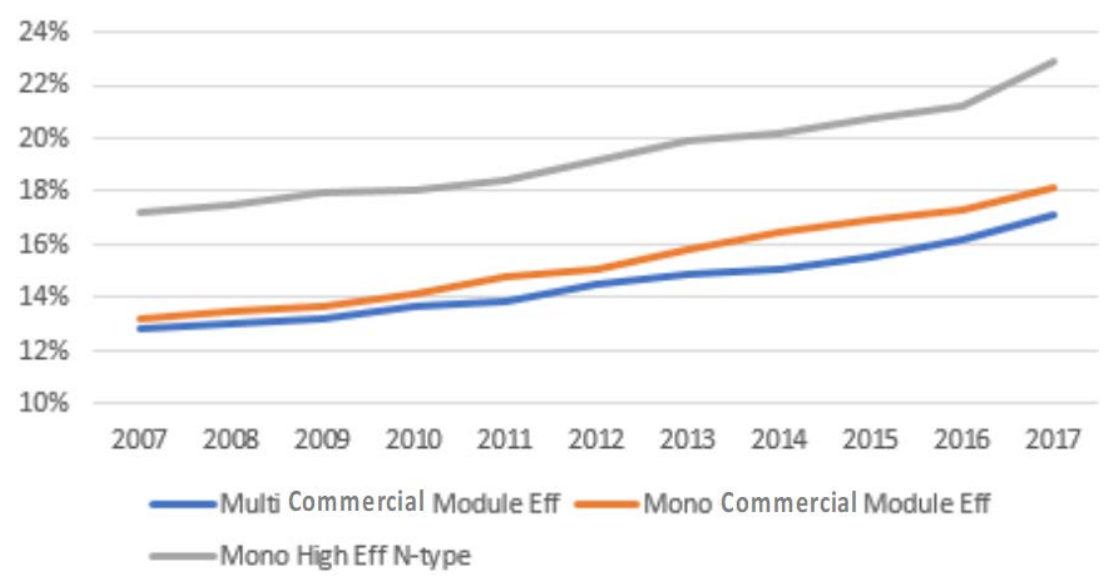

Figure 4. Module efficiency for ci-Si PV, 2007-2017 (BNEF 2018)

The rapid cost decline and increased performance of c-Si technology during the past decade have been key factors driving expansion of the c-Si PV industry. Keeping up with the pace of cost reductions in c-Si PV technology has been challenging for non-c-Si PV technologies. In the PV industry today, c-Si technology cost (including performance and reliability) sets the bar for new technologies to enter the market. The cost of PV modules has decreased to the point where they no longer represent the largest share of PV system cost. Figure 5 shows a cost breakdown of PV systems annually since 2010, showing PV module costs fell rapidly as a share of total PV system costs between 2010 and 2013 (Fu, Margolis, and Feldman 2018). While non-hardware ("soft") costs now account for more than half of the installed system costs for residential and commercial systems, hardware (modules, inverter, and structural and electrical components) accounts for up to $64 \%$ of installed costs for utility-scale PV systems.

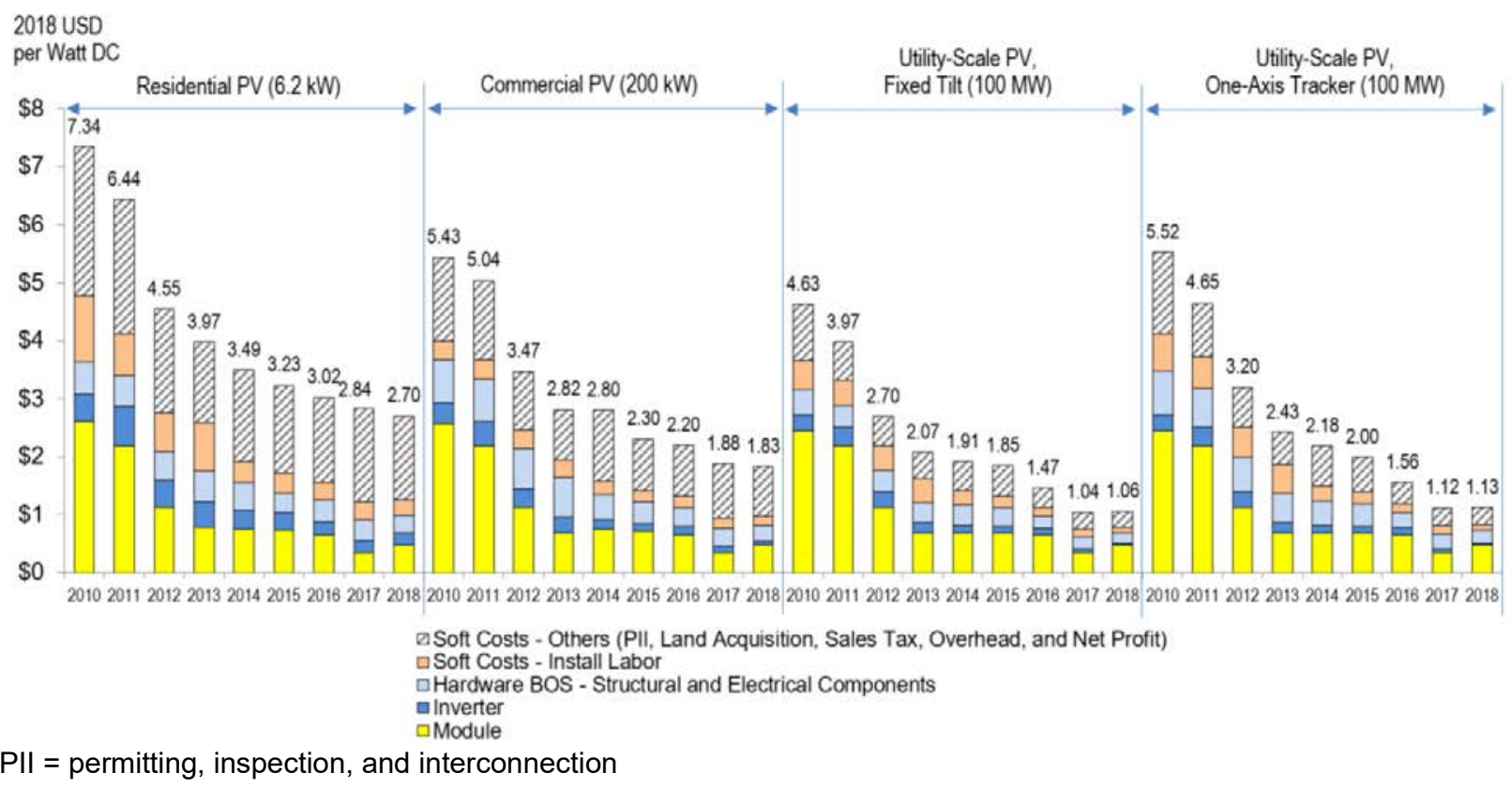

Figure 5. National Renewable Energy Laboratory PV system cost benchmark summary for residential, commercial, and utility-scale systems, 2010-2018 (Fu, Margolis, and Feldman 2018) 
Because of the dominance of c-Si technologies in the global PV industry, this section focuses on the c-Si segment of the PV supply chain (Figure 6). Polysilicon, wafer, cell, and module manufacturing in the United States have faced significant challenges over the last decade. Falling prices, high barriers to market entry such as scale and capital expenditures, offshore competition, and other changes have contributed to volatility in these manufacturing segments. Section 2.4 analyzes the key aspects of the PV supply chain beyond the c-Si components.

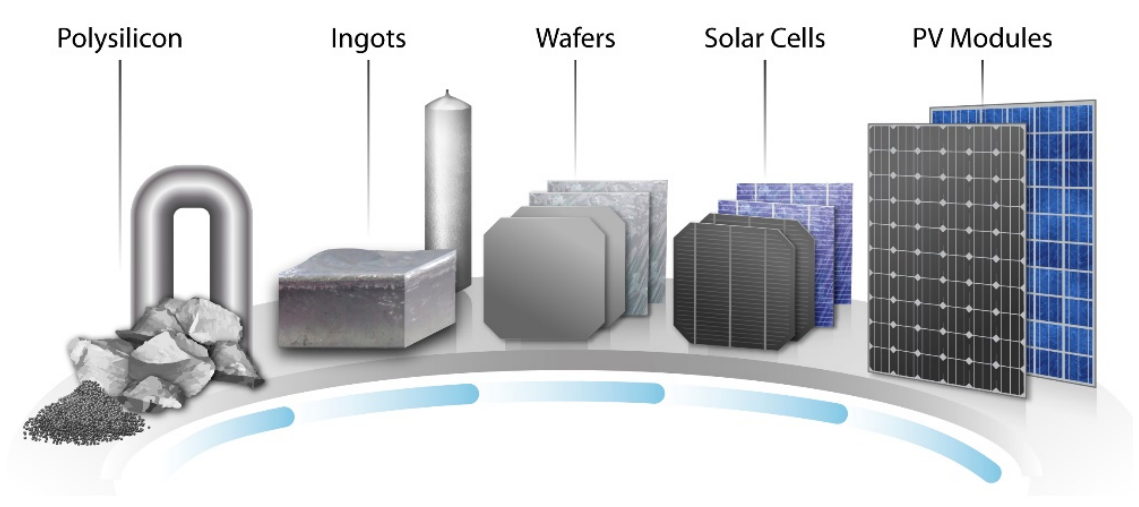

Figure 6. Schematic of the c-Si portion of the PV supply chain

\subsection{Polysilicon}

The United States was once the dominant producer of polysilicon, in part because of the material's primary manufacturing use in the semiconductor chip industry, which had strong origins in the United States. In the 20th century, more than $80 \%$ of polysilicon was consumed by the semiconductor industry. As the PV market evolved, polysilicon production demand shifted from the semiconductor chip industry to the PV industry. By 2016, more than $90 \%$ of the global polysilicon market was consumed by PV (Sandor et al. 2018). For reference, the term polysilicon can refer to polycrystalline silicon with $99.9 \%$ purity or greater (also referred to as three nines, or $3 \mathrm{~N}$ ), but in recent years PV production has increasingly relied on silicon with $9 \mathrm{~N}$ to $11 \mathrm{~N}$ purity (Woodhouse et al. 2019).

Total U.S. silicon production in 2017 was 405,000 metric tons (MT), including both ferrosilicon (an alloy of iron and silicon) and metallurgical-grade (mg) silicon (silicon with 98\% to 99\% purity) (U.S. Geological Survey 2018). Production occurred at eight plants, all east of the Mississippi River. Metallurgical-grade silicon was primarily used in aluminum alloys, while high-purity polysilicon for solar and electronic applications (9N to $11 \mathrm{~N})$ represented less than $10 \%$ of total silicon production (U.S. Geological Survey 2018). Trade data for silicon are available in three categories according to the Harmonized Tariff Schedule (HTS) (USITC 2017):

1. Ferrosilicon containing more than 55\% silicon by weight (HTS code 7202.21)

2. Silicon with $<99.99 \%$ purity (HTS code 2804.69 )

3. Silicon with $>99.99 \%$ purity (HTS code 2804.61 )

Figure 7 depicts domestic solar-grade polysilicon production and capacity from 2010 through 2017. As of 2017, the United States had excess manufacturing capacity for solar-grade polysilicon. Assuming it takes $3 \mathrm{~kg}$ of polysilicon to make a state-of-the-art 1-kW 
monocrystalline $21.5 \%$-efficient module (Woodhouse et al. 2019), the 30,000 MT of polysilicon produced in the United States in 2017 could have created approximately $10 \mathrm{GW}$ of PV modules, if exclusively used for PV. Full capacity utilization could have produced more than $20 \mathrm{GW}$ of PV modules. We use these data to construct Figure 8, which illustrates that 2017 domestic solargrade polysilicon production was equivalent to roughly half of $>99.99 \%$ silicon 2017 exports. Of these exports, $72 \%$ went to Japan, Taiwan, South Korea, and China. It is unknown what fraction of domestic solar-grade polysilicon was used to produce domestic silicon wafers for electronic applications, but none was used to produce domestic wafers for solar applications, because no such firms currently exist in the United States. However, domestic production of c-Si PV cells in 2017 was approximately 0.26 GW (GTM Research and SEIA 2018), and therefore domestic solar-grade polysilicon production was significantly greater than the amount needed for all domestic c-Si PV cells in 2017. Ultimately, it is unclear what fraction of the imported c-Si wafers needed for all domestic PV cell production were manufactured using domestic polysilicon.

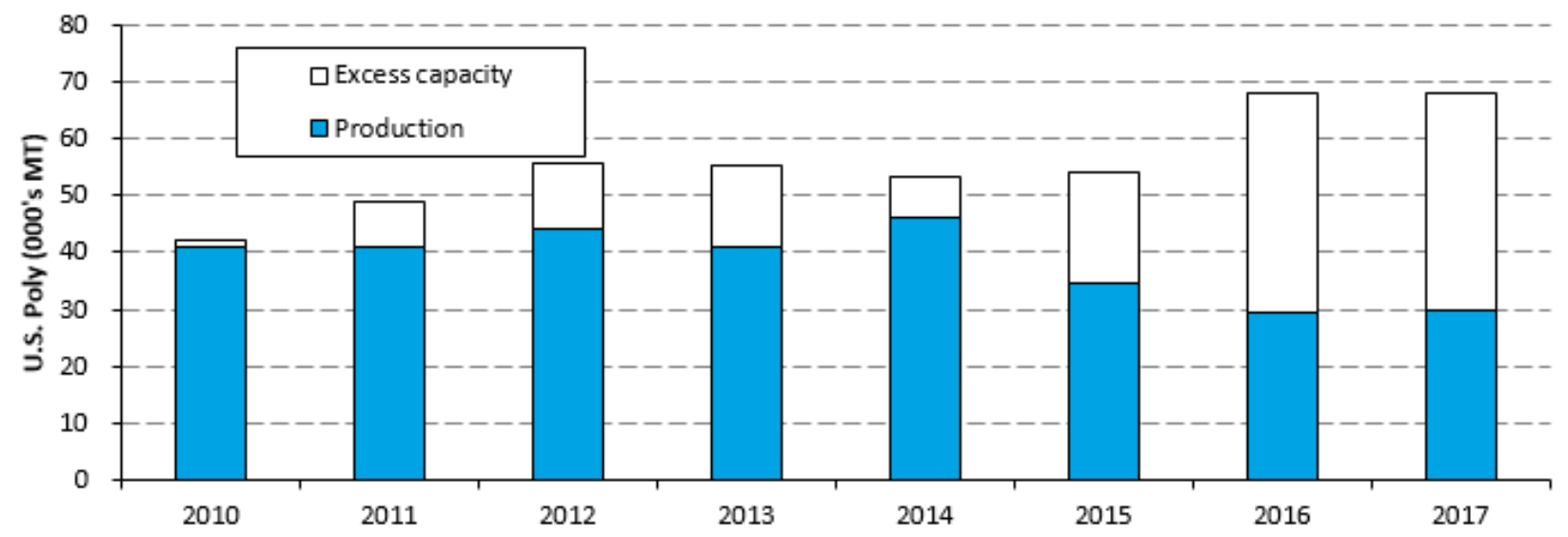

Figure 7. U.S. solar-grade polysilicon production and capacity from 2010-2017 (GTM Research and SEIA 2017, 2018, 2011, 2012, 2013, 2014, 2015, 2016)

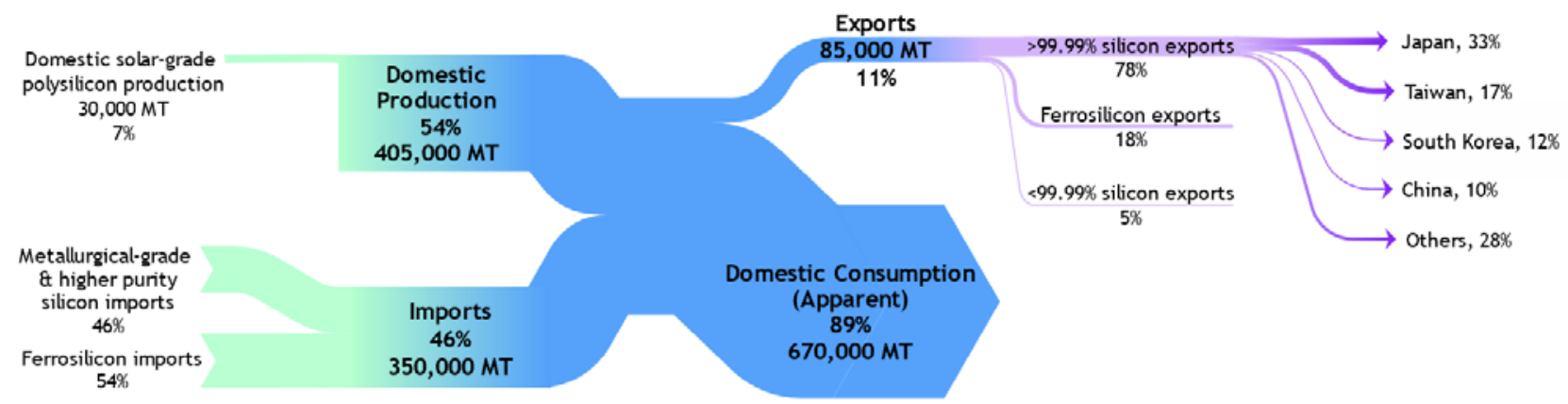

Figure 8. U.S. silicon trade flows in 2017 in MT

Note: Figure includes silicon product flows other than polysilicon.

\subsection{Wafers and Ingots}

Panasonic, SolarWorld, and SunEdison previously produced polysilicon ingots and wafers for PV in the United States, but they halted all ingot and wafer production in 2017, 2016, and 2013, respectively (Read 2013, Shumkov 2016, Andorka 2017). Silicon wafer production in the United 
States in 2017 primarily served electronics applications rather than solar applications (GlobalWafers 2018). The major U.S. silicon wafer producers were SEH America, GlobalWafers, Virginia Semiconductor, and WaferWorld. Other U.S. companies involved in the silicon wafer market in 2017 used U.S. polysilicon but did not produce the wafers domestically. For example, Silicon Materials, Inc., a U.S. company headquartered in Pittsburgh, bought polysilicon from Hemlock (a U.S. polysilicon producer) and shipped it to Ukraine to be made into ingots and wafers (Silicon Materials Inc. 2018).

\subsection{Cells and Modules}

Figure 9 shows the recent history of PV cell and module production in the United States. Significant excess capacity existed in most years, with the exception of 2016, which exhibited a peak in demand. Though c-Si PV cell manufacturing capacity in 2017 approached $1 \mathrm{GW}$, less than one third of capacity was actually used for cell production. This is significantly different from the global PV cell manufacturing utilization rate in 2017, which was 85\% (SPV Market Research 2018). Cell capacity increased in 2017 owing to Solaria's expansion to $40 \mathrm{MW}$, but production decreased because of SolarWorld and Suniva ceasing operations. Similarly, U.S. module capacity in 2017 approached $1.5 \mathrm{GW}$, but less than half was used. New module capacity in 2017 included capacity from Tesla, Itek Energy, China Sunergy (CSUN), and Solaria, while the idling of Suniva and SolarWorld operations again resulted in decreased production. Thin-film PV also experienced a decrease in production in 2017, though the overall capacity declined as well.

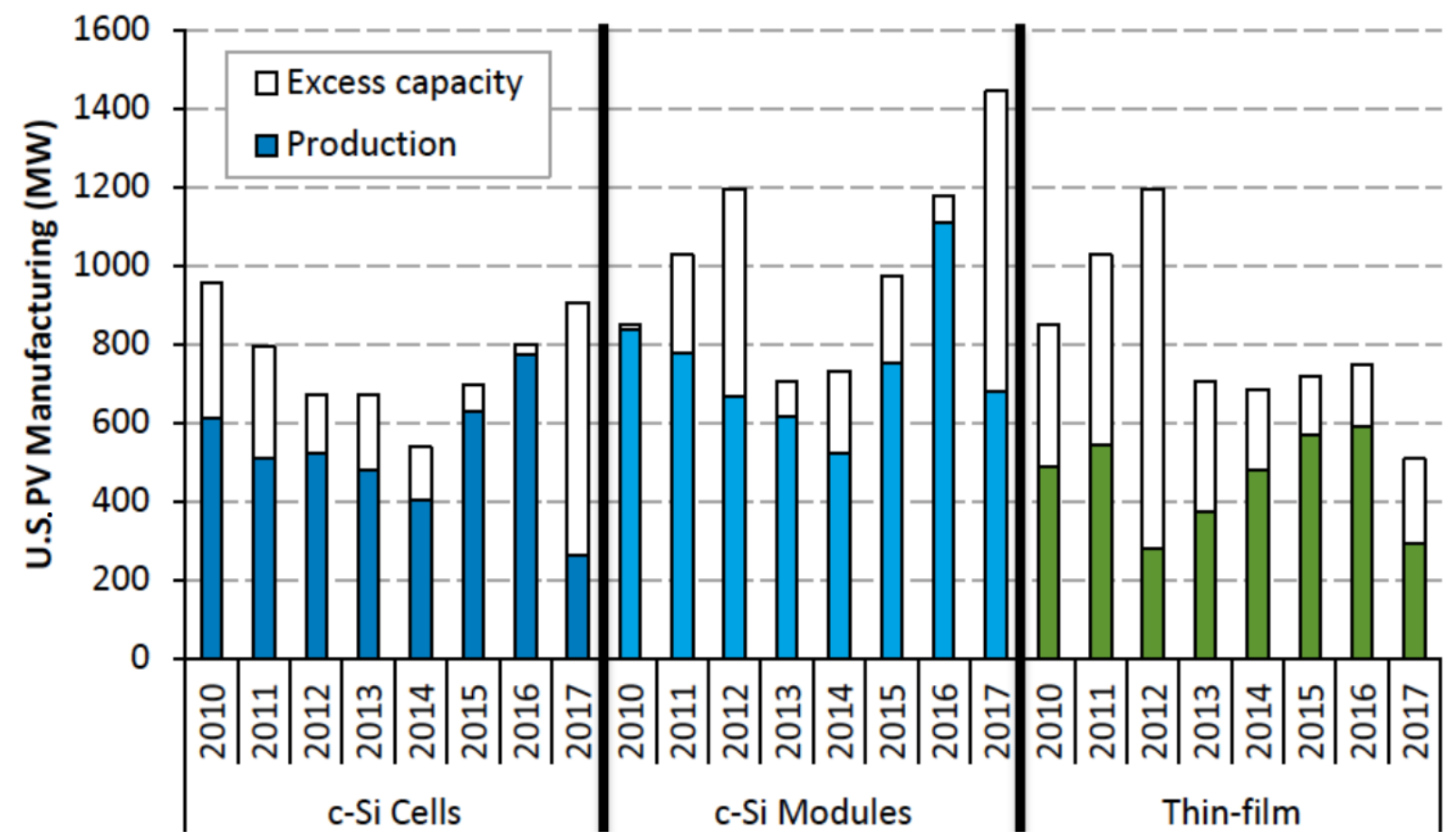

Figure 9. U.S. cell and module production and capacity from 2010-2017 (Feldman, Margolis, and Hoskins 2018)

Given that U.S. PV demand approached $11 \mathrm{GW}$ in 2017, there was a significant gap between domestic demand and domestic supply (GTM Research and SEIA 2018). This gap between domestic production and demand for PV cells and modules in 2017 was filled by imports. The 
2017 U.S. market flows for PV cells and modules are displayed in Figure 10 and Figure 11, respectively (USITC 2017).

The supply side of Figure 10 shows $0.26 \mathrm{GW}$ of domestic cell production, and imports of PV cells were reported to be $\$ 111$ million (USITC 2017). To appropriately convert the GW of domestic cell production into U.S. dollars (USD), and likewise convert the import USD value into GW, different cell prices must be used:

Domestic cell pricing. Because average 2017 U.S. wafer prices were $\$ 150$ million/GW (GTM Research and SEIA 2018), we assume domestic cells were priced at $\$ 270$ million/GW based on modeled U.S. cell conversion costs (Woodhouse et al. 2019). This means the total value of $0.26 \mathrm{GW}$ of U.S. cell production corresponds to $\$ 70$ million.

Imported cell pricing. We assume that imported cells were priced at $\$ 190$ million/GW, which is slightly higher than the lowest cost modeled in Woodhouse et al. (2019). This indicates $\$ 111$ million of imported cells would be equivalent to $0.58 \mathrm{GW}$.

To validate these assumptions, it is useful to note that these two prices correspond to a weighted average of $\$ 220$ million/GW as shown by Equation 1, which is consistent with the average U.S. cell price reported in GTM Research and SEIA (2018).

$$
[60 \% \times \$ 190 \text { million } / \mathrm{GW}]+[40 \% \times \$ 270 \text { million } / \mathrm{GW}]=\$ 220 \text { million } / \mathrm{GW}
$$

The demand side of Figure 10 relies on four assumptions:

1. Domestic cell consumption was $0.68 \mathrm{GW}$ (equivalent to 2017 U.S. c-Si module production).

2. $0.56 \mathrm{GW}$ of imported cells were consumed for domestic module production.

3. All exported cells were domestically produced.

4. Domestic cell production of $0.1 \mathrm{GW}$ was consumed for domestic module production.

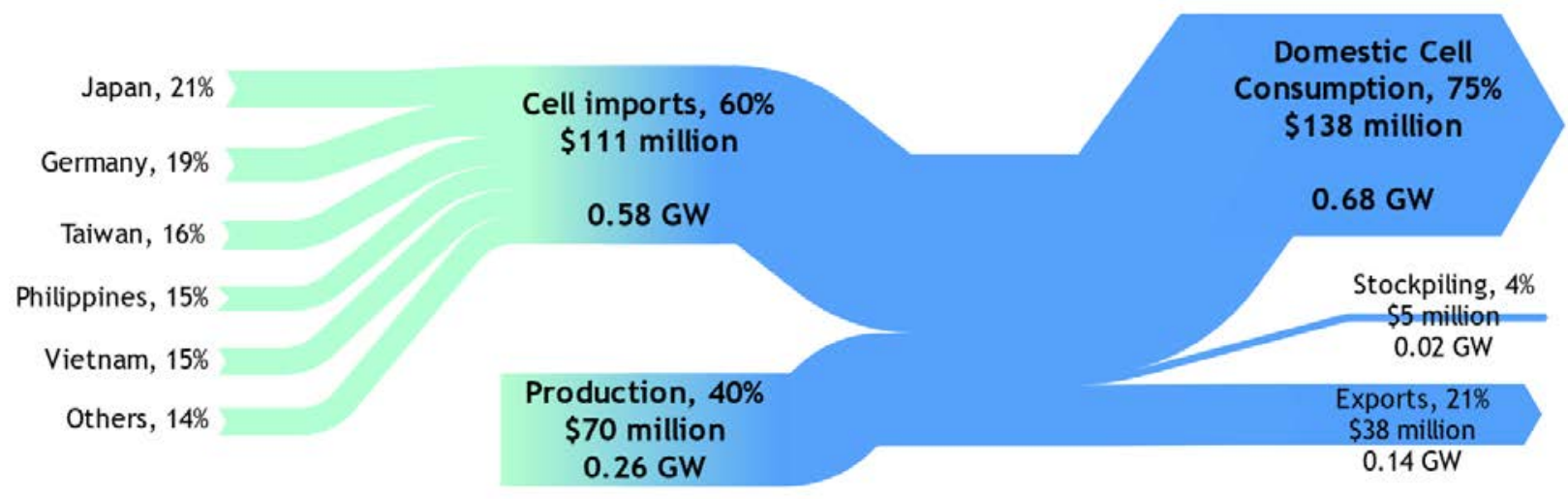

Figure 10. U.S. PV cell trade flows in 2017, based on HTS code 8541.40 .6030 (USITC 2017)

Using the above assumptions and the aforementioned import versus domestic cell pricing, 0.68 $\mathrm{GW}$ of domestic consumption corresponds to a total value of $\$ 138$ million. Similarly, the amount exported as reported by the U.S. International Trade Commission (USITC, $\$ 38$ million) corresponds to $0.14 \mathrm{GW}$. This creates a leftover flow of $\$ 5$ million, which we assume represents 
$20 \mathrm{MW}$ of stockpiling efforts (using an average $\$ 220$ million/GW cell price) due to policy uncertainty.

The supply side of Figure 11 shows 1 GW of U.S. PV module production in 2017 (roughly 680 MW c-Si and $300 \mathrm{MW}$ thin film) and $\$ 5.1$ billion worth of module imports (USITC 2017). To convert GW of U.S. module production to USD value, and to convert import value to GW, we assume an average 2017 module price of $\$ 0.43$ billion $/ \mathrm{GW}$ for both c-Si and thin-film modules (GTM Research and SEIA 2018). Thus, the total amount of modules produced in the United States in 2017 was worth about $\$ 0.4$ billion, while about $11.9 \mathrm{GW}$ of modules were imported in 2017.

On the demand side of Figure 11, exports of PV modules in 2017 were reported to be $\$ 0.06$ billion by the USITC, which corresponds to $0.14 \mathrm{GW}$, again assuming the average module price defined above. Given that the total installed U.S. PV in 2017 was $10.5 \mathrm{GW}$, this indicates that only $9.7 \mathrm{GW}$ of imported modules were actually needed in 2017 . We assume the remainder of imported modules $(2.2 \mathrm{GW})$ in 2017 were stockpiled. USITC data reported that, during 2017, the value of modules imported in the final quarter had roughly quadrupled compared to the first quarter, which likely reflects stockpiling efforts due to policy uncertainty.

To validate our module analysis in Figure 11, we compare our data to data from the U.S. Energy Information Administration (EIA), which indicates that $10 \mathrm{GW}$ of modules were imported in 2017, while roughly $1 \mathrm{GW}$ was produced domestically and $0.3 \mathrm{GW}$ were exported (U.S. Energy Information Administration 2017). This would imply that only $0.2 \mathrm{GW}$ of modules were stockpiled. However, EIA does not report a change in inventory number owing to poor data quality (as indicated in Table 6 of the EIA report). The discrepancy is thus likely due to datacollection issues with the EIA survey, which may underreport imports.

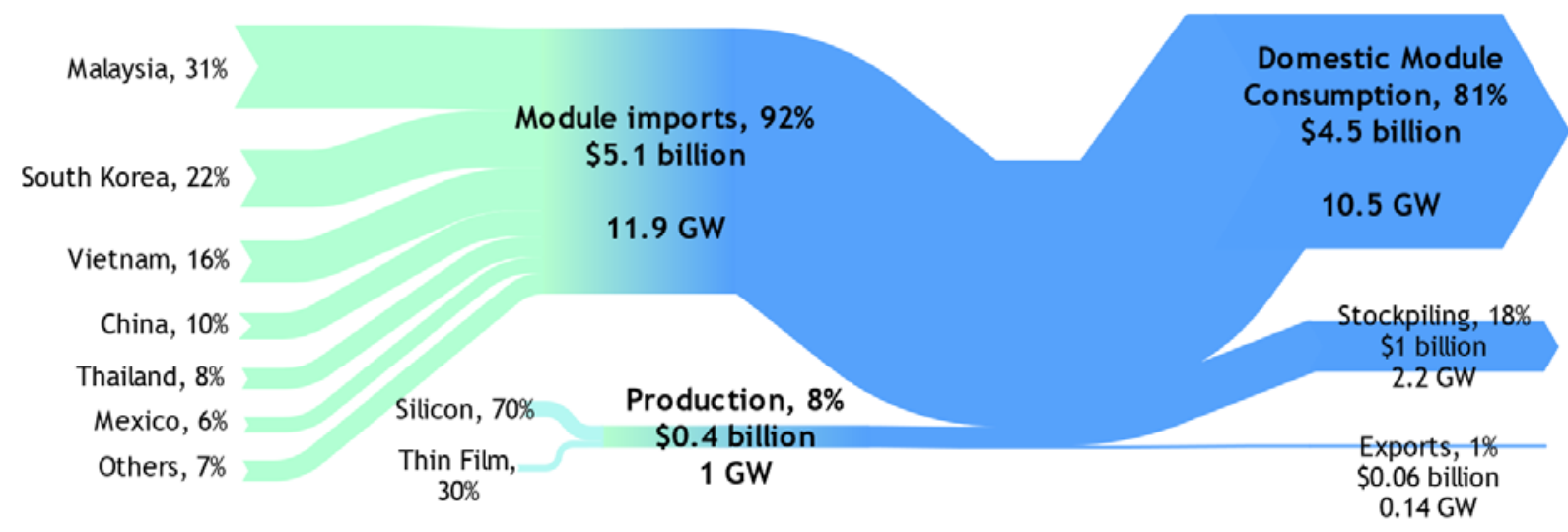

Figure 11. U.S. PV module trade flows in 2017 (including c-Si and thin film), based on HTS code 8541.40.6020 (USITC 2017)

Rapidly declining prices for imported PV cells and modules have created a challenging environment for domestic PV production during the past decade. Some analysis of regional drivers is provided in Goodrich et al. (2013); the authors identified areas for U.S. opportunity including product differentiation, advanced cell architectures, and increased automation. Since 2012, a series of U.S. legislative efforts has impacted the competitiveness of U.S. PV manufacturing. In 2012 and 2014, the United States imposed anti-dumping duties on Chinese 
manufacturers (U.S. International Trade Administration 2012, 2015). During the following years, imports shifted from China to Taiwan, Korea, and Malaysia. In 2018, tariffs were levied against imports of c-Si PV cells and modules (referred to as "Section 201 tariffs") from an extensive list of countries (U.S. Customs and Border Protection 2018a). Tariffs were also levied against imports of foreign aluminum and steel in 2018, which are used in both PV module construction and PV racking (U.S. Customs and Border Protection 2018b). Most recently, tariffs on a number of PV components and module materials included on a long list of other non-PV goods imported from China were also introduced (U.S. Customs and Border Protection 2018c). The impacts of these tariffs are yet to be fully analyzed, though some analysis of the earlier policies has been conducted (Sandor et al. 2018).

Developments in domestic PV manufacturing in late 2017 through 2019 need to be evaluated in the context of the recent tariffs, corporate tax cuts, and local or state incentives. An exhaustive list of existing U.S. solar manufacturing locations as well as announcements from late 2017 through mid-2019 are reported in the appendix. Many existing companies with c-Si module assembly capacity have announced planned capacity expansions, such as Mission Solar $(+200$ MW) and Seraphim Solar (+340 MW). Thin-film CdTe PV manufacturer First Solar, which is notably not subject to any Section 201 tariffs, also announced plans for a new 1.2-GW facility in Ohio shortly after the tariffs were implemented (Pickerel 2018a). Multiple U.S. c-Si PV manufacturing facilities that were closed in 2017 or earlier are in the process of becoming operational again under a new company. Some of these old facilities are being operated by domestic companies, such as SunPower, which is in the process of acquiring the old SolarWorld cell and module production facilities in Oregon (Danko 2018). Others are planned to be revived by foreign companies, such as the Canadian-owned Heliene, which plans to operate the old Silicon Energy facility in Minnesota (Jossi 2018). Similarly, Silfab (a Canadian subsidiary of an Italian parent company) plans to purchase a facility from Itek Energy and increase the capacity of the facility from $120 \mathrm{MW}$ to $400 \mathrm{MW}$ (Roselund 2019).

Furthermore, completely new c-Si module manufacturing facilities are planned to be constructed in the United States by foreign companies such as Hanwha Q Cells (1,600 MW, Korea), JinkoSolar (400 MW, China), LG Electronics (500 MW, Korea), and CSUN (600 MW, China) (Osborne 2018, Deign 2018, Pickerel 2018c) as well as domestic companies such as GreenBrilliance (125 MW), SunPreme (400 MW), and SolarTech Universal (180 MW) (Weaver 2018, GreenBrilliance USA 2018, Gallagher 2017, Foehringer Merchant 2018). A number of these new sites are located in the southeastern United States, while many existing facilities are located in industrial centers that have been hubs for traditional manufacturing. Figure 12 shows the locations and production capacities for U.S. solar manufacturing facilities in operation near the end of 2017, whereas Figure 13 displays new or expanded capacity announcements from late 2017 through mid-2019.

In total, PV manufacturing expansions announced since late 2017 correspond to approximately $6.2 \mathrm{GW}$ of anticipated additional c-Si module production capacity, 1.2 GW of additional thinfilm production capacity, and $1.6 \mathrm{GW}$ of additional c-Si cell production capacity. This would correspond to a total of $9.6 \mathrm{GW}$ of module capacity (including $2.1 \mathrm{GW}$ of thin-film module capacity) and $1.8 \mathrm{GW}$ of c-Si cell capacity. Note that historically, announcements often take longer than expected to translate into operational plants, or the announced projects are abandoned prior to reaching the production stage. 
The gap between U.S. c-Si module and cell capacity $(5.7 \mathrm{GW})$ on an annual basis would need to be filled by imported cells, which would be subject to tariffs after the first $2.5 \mathrm{GW}$ of cell imports. However, as of May 2019, only 5.6 GW of c-Si module capacity and 1.1 GW of cell capacity are currently operational or have started production and are expected to become fully operational. These numbers include all existing facilities in 2017 as well as the new facilities from Hanwha Q Cells, Jinko Solar, LG Electronics, Heliene, Solar Electric America, and SunPower, and also increased production at facilities owned by Auxin Solar, Silfab, and Tesla/Panasonic. These facilities still correspond to a gap of $4.5 \mathrm{GW}$, which may be further exacerbated by the fact that cells manufactured at the Tesla/Panasonic facility are primarily being exported (Groom 2019). 


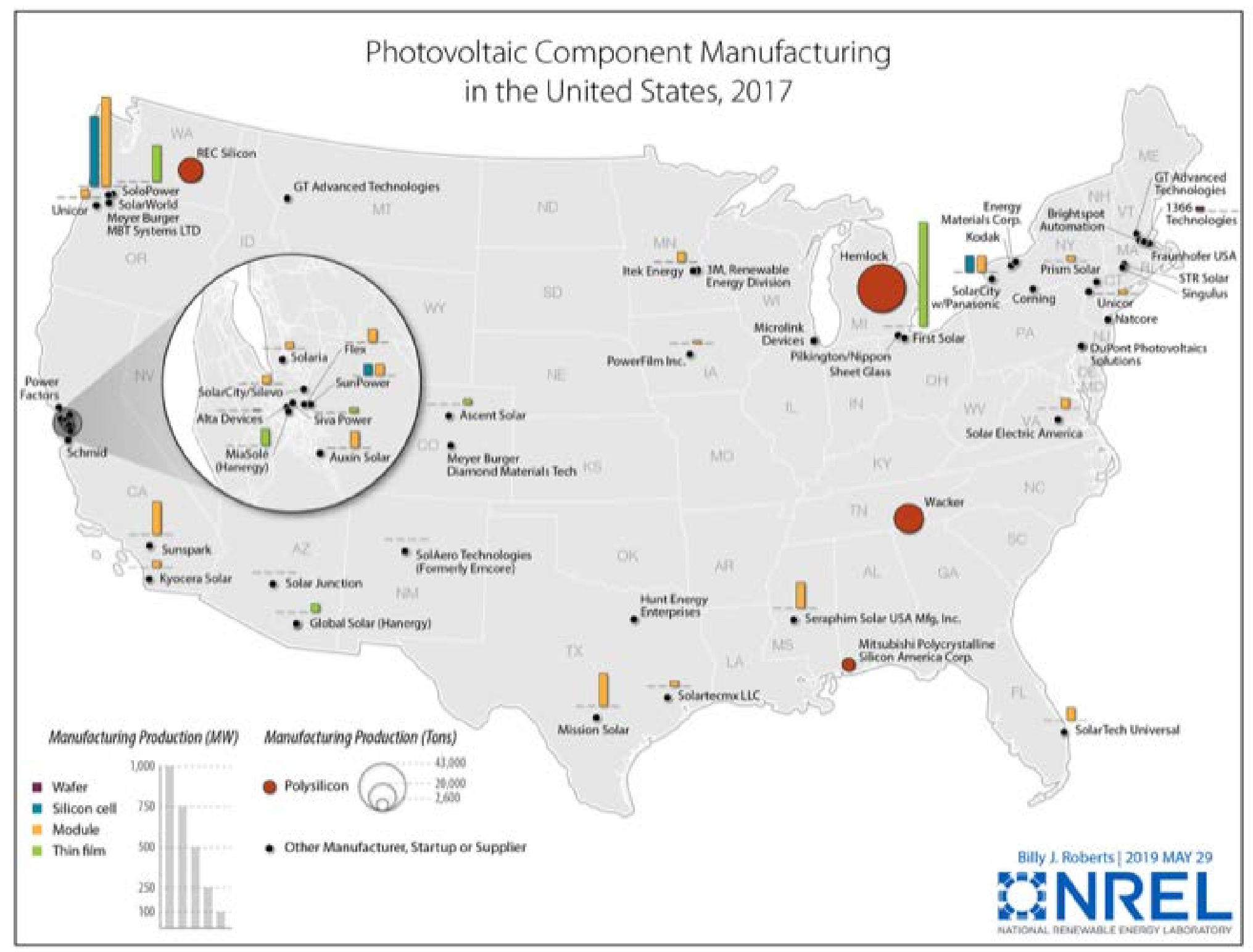

Figure 12. U.S. wafer, cell, module, and polysilicon production facilities in operation, mid-2017 


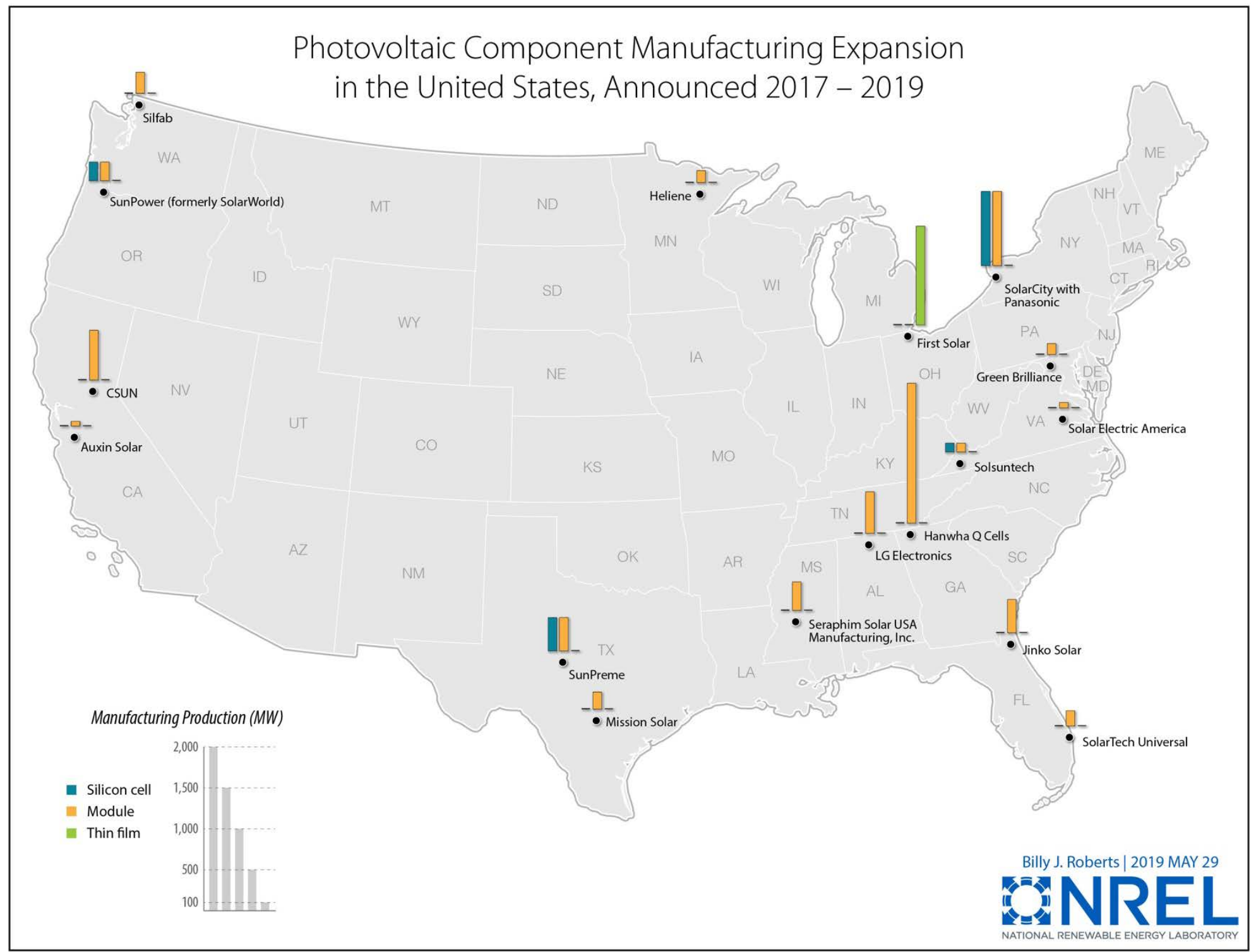

Figure 13. Planned additions of PV cell and module production capacity, announced in 2017-2019 (note: SoloPower facility closed permanently, SunPower and Silfab locations acquired from SolarWorld and Itek, respectively) 


\subsection{CapEx}

Historically, the barrier to entry for PV manufacturers (initial capital expenditures) was often difficult to overcome when other manufacturers may have received more generous incentives to build a manufacturing facility. Many of the lasting solar companies in the United States have found themselves either specializing in a differentiated product or vertically integrating to sectors that cannot be moved, or would be too difficult to move, offshore.

The dollar amount for the initial capital expenditure necessary to build PV manufacturing infrastructure (facilities and equipment) is commonly abbreviated to just manufacturing capital expenditure or "CapEx." Within the PV community, the units of CapEx depend on the specific step within the supply chain. As shown in Figure 14, CapEx for equipment has decreased by around $85 \%$ over the past 10 years. CapEx has been tracked in PV cost models over the past decade (Maycock and Bradford 2007, Goodrich, James, and Woodhouse 2011, Goodrich, Hacke, et al. 2013, Powell et al. 2015), and was most recently benchmarked for the first half of 2018 (Woodhouse et al. 2019).

The assumptions used for the most recent benchmark are reported in Table 1. For the purposes of building a bottom-up cost model, fixed investments in PV manufacturing are typically allocated as a depreciation expense according to a linear schedule. The length of these schedules varies from 5-10 years for manufacturing equipment and 15-25 years for buildings and other facilities. These assumptions are used to calculate that the amount of investment required to build a fully scaled greenfield 20,000 MT per annum (MTPA) Siemens solar-grade polysilicon plant would be $\$ 600-\$ 900$ million, and a $1-G W$ standard passivated emitter and rear cell (PERC) line would require $\$ 40-\$ 80$ million.

The progress in CapEx reductions has primarily been the result of technology advances and economies of scale. The CapEx reductions observed for polysilicon production have been the result of using larger reactors for producing polysilicon rods and reductions in net silicon use (the amount of silicon present in a finished wafer divided by wafer power in watts) due to thinner wafers and reduced sawing losses. Efficiency gains at the cell and module level (more watts per unit area) have also lowered the \$/W CapEx expectations for c-Si. Reductions in ingot and wafer CapEx have been driven by larger ingot sizes, faster Czochralski $(\mathrm{Cz})$ ingot pulling rates, reduced tool prices, and higher throughput in wafering. Diamond wire wafering in particular has enabled faster wafer cutting speeds, improved equipment uptime, and overall reduced CapEx. Cell manufacturing lines have been able to achieve higher throughputs, and CapEx has also declined as cell efficiencies have improved. Prior to 2010, it was typical to have less than 2,000 cells per hour throughput for state-of-the art lines. Today's throughputs are approaching up to 6,000 cells per hour for state-of-the-art manufacturing lines. 
Table 1. Assumptions Used in First Half of 2018 CapEx Benchmark, for c-Si PV Supply Chain

\begin{tabular}{|c|c|}
\hline Polysilicon & $\begin{array}{l}\text { CapEx including engineering, procurement, and construction (EPC): (1) } \\
\text { Siemens solar grade: } \$ 40-\$ 45 / \mathrm{kg} \text { in U.S. or Europe and } \$ 30-\$ 35 / \mathrm{kg} \text { in China. } \\
\text { (2) Siemens electronic grade: } \$ 45-\$ 50 / \mathrm{kg} \text { in U.S. or Europe and } \$ 35-\$ 40 / \mathrm{kg} \text { in } \\
\text { China. (3) Fluidized bed reactor: } \$ 80-\$ 120 / \mathrm{kg} \text { in U.S. or Europe and } \$ 70- \\
\$ 80 / \mathrm{kg} \text { in China. As an industry convention, the blended equipment and } \\
\text { facilities CapEx is then allocated over a } 10-\text { year straight-line depreciation } \\
\text { schedule. }\end{array}$ \\
\hline Ingots and wafering & $\begin{array}{l}\text { Capital equipment: Original CapEx of } \$ 0.07-\$ 0.10 / \mathrm{W} \text { of capacity for } \mathrm{Cz} \text { and } \\
\$ 0.02-\$ 0.05 / \mathrm{W} \text { of capacity for directional solidification (DS). A working } \\
\text { assumption is } 7 \text {-year straight-line depreciation for DS furnaces, 10-year } \\
\text { straight-line depreciation for } \mathrm{Cz} \text { pullers, and 7-year straight-line depreciation for } \\
\text { all other testing, ingot-shaping, and wafering equipment. }\end{array}$ \\
\hline
\end{tabular}

Manufacturing facilities: Original CapEx of $\$ 0.02-\$ 0.06 / \mathrm{W}$ for new facilities, 20-year straight-line depreciation.

Cell conversion

Capital equipment: Total equipment CapEx of $\$ 0.04-\$ 0.08 / \mathrm{W}$ for standard full-area aluminum back surface field (AI BSF) cell lines. Total equipment CapEx of $\$ 0.06-\$ 0.10 / \mathrm{W}$ and facility CapEx of $\$ 0.03-\$ 0.06 / \mathrm{W}$ for PERC cell lines. For baseline total equipment and facilities CapEx: wafer testing $(\$ 0.010 / \mathrm{W})$, saw damage removal and surface texturization $(\$ 0.027 / \mathrm{W}), \mathrm{POCl}_{3}$ diffusion and phosphosilicate glass removal $(\$ 0.023 / \mathrm{W})$, front and backside anti-reflection and passivation layers $(\$ 0.039 / \mathrm{W})$, laser contact opening $(\$ 0.006 / \mathrm{W})$, screen-print and cofire $(\$ 0.016 / \mathrm{W})$, and cell testing and packaging $(\$ 0.012 \mathrm{~W})$. 5-year straight-line depreciation.

Manufacturing facilities: $\$ 0.03-\$ 0.06 \mathrm{~W}$ total for new building and facility CapEx. 20-year straight-line depreciation.

Module assembly

Capital equipment: Total equipment CapEx of \$0.03-\$0.05/W for standard and PERC modules. 5-year straight-line depreciation.

Manufacturing facilities: 20-year straight-line depreciation. \$0.04/W total building and facility CapEx.

As per-tool prices have also decreased due to increasing competition within the PV manufacturing equipment sector, and as throughputs have increased, the dollars-per-cell CapEx has decreased. As average commercial production cell efficiencies have improved from $17.5 \%$ in 2007 to $21 \%-22 \%$ today, the calculated \$/W CapEx has also decreased. Finally, faster robotic handling equipment, improved factory layout, lower tool prices due to increased competition, and improved efficiencies have lowered the CapEx for module assembly.

This overall progress in CapEx reductions means that, for many manufacturers, the nextgeneration tools cost less than the depreciated value of their current assets. As overall capital costs decrease and manufacturers continue to increase automation, the cost differences between imported products and domestically manufactured products become smaller. The cost difference between local production and the added cost of shipping may become a key cost driver (Goodrich, Powell, et al. 2013). This could encourage a return of production to the United States as automation increases. As PV demand increases, vertically integrated production sites close to consumption may represent a cost-effective option. 


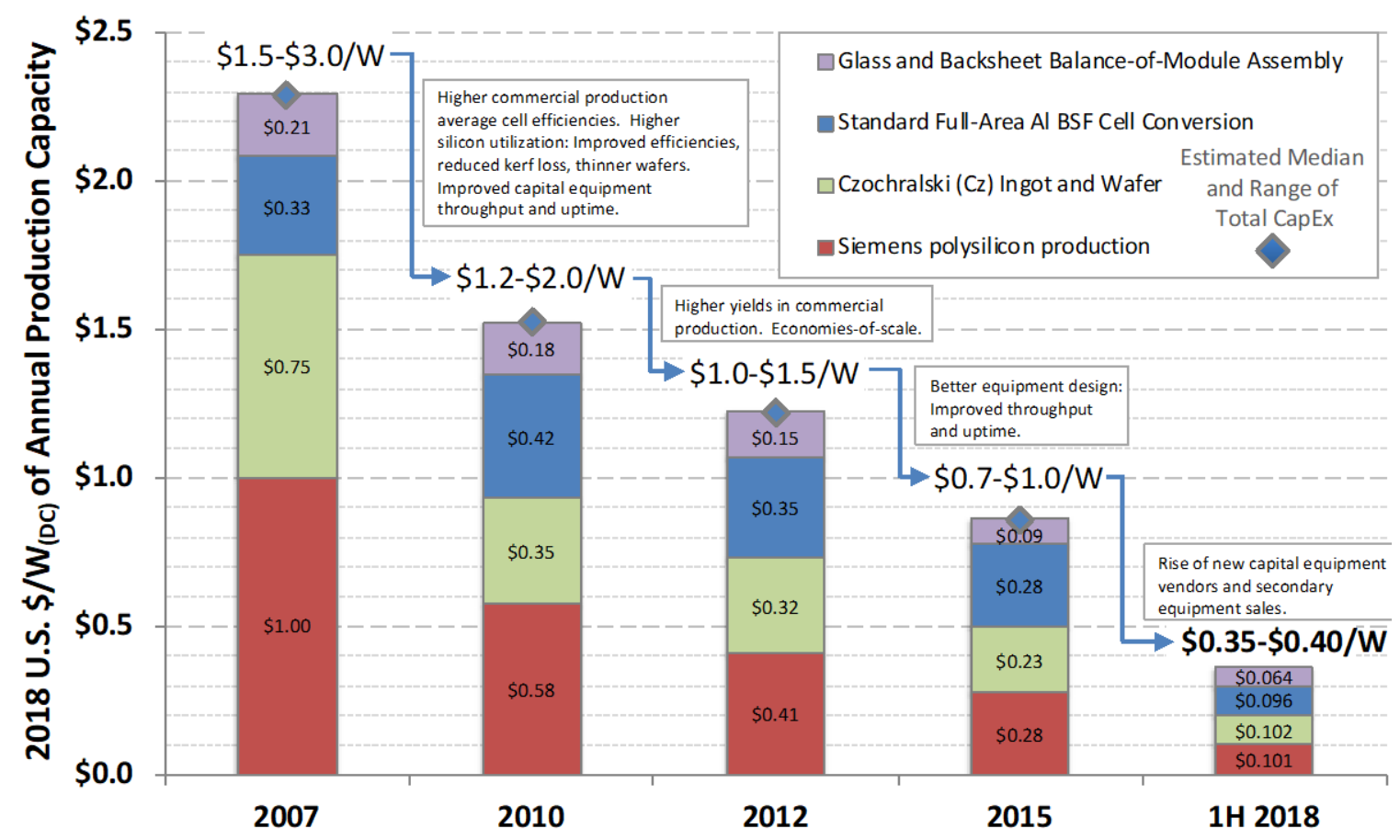

Figure 14. Historical CapEx for PV component production at $>100 \mathrm{MW}$ capacity greenfield facilities

Moving beyond the polysilicon-to-module supply chain, we turn next to the supply chains for other components and materials required for PV systems.

\section{Upstream Materials and Components in the PV Supply Chain}

Although the trajectory of polysilicon through the PV supply chain is important, additional materials and components are required to produce and install complete PV systems. Here we focus on other key materials in the PV supply chain, including non-silicon materials used in producing PV modules as well as those used in producing balance-of-system (BOS) components. Table 2 breaks down the main materials used in manufacturing and constructing a PV system.

Table 2. Common Materials in PV Systems and Their End Uses

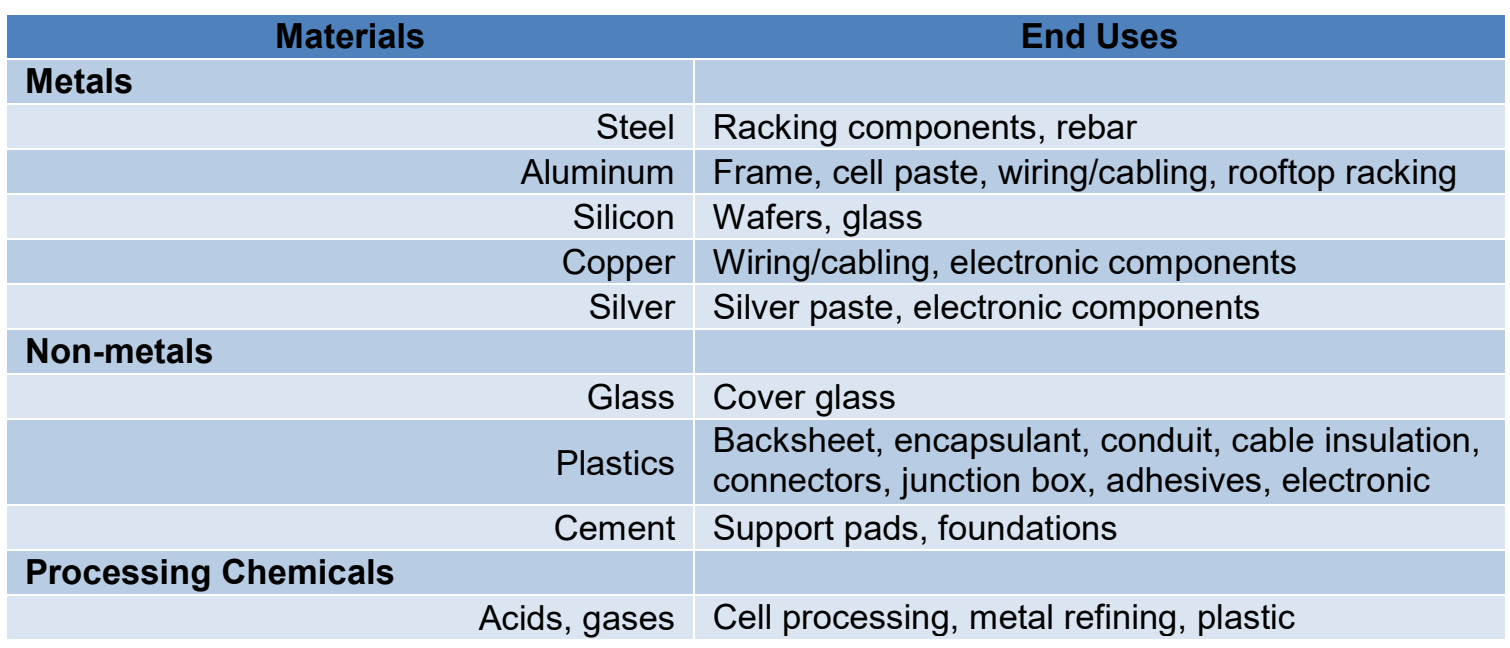


To prioritize which components and materials would benefit most from detailed supply chain examination, we analyzed the cost and mass of components in installed PV systems based on the data available in Fu et al. (2017), Woodhouse et al. (2019), and Michael and Selvarasan (2017). The costliest components would provide the most value, while characterizing mass can highlight heavy components that are complex or fragile - such as solar-grade glass or steel single-axis trackers - and suggest which components may be more cost-effective to manufacture close to demand. We performed this analysis separately for utility-scale, commercial, and residential PV systems. The distinction between commercial (often referred to as "non-residential") and utilityscale varies among researchers; typically, commercial systems are defined as being 2-5 MW in size (Fu et al. 2017, Barbose et al. 2017). The mix of materials used varies depending on installation type due to differences in system size and location.

Beginning our analysis with racking, it is typical for utility-scale systems to be ground-mounted and thus they can rely on steel racking, while residential systems are typically installed on rooftops and often require lightweight aluminum racking. However, because between one third and two thirds of commercial PV systems are ground-mounted (based simply on the number of installations) (Barbose et al. 2017), for this report we assume that half of all commercial systems are ground-mounted. For simplicity we also assume that all ground-mounted systems use steel racking, and all roof-mounted systems use aluminum racking. Furthermore, about $80 \%$ of ground-mounted systems use single-axis trackers while the other $20 \%$ have a fixed tilt (Weinshenker 2017). However, only 5\% of commercial systems use single-axis tracking, so we assume that the remaining ground-mounted commercial systems (45\% of all commercial systems) use a fixed-tilt configuration. The total 2017 installations for each system type and each type of racking are shown in Table 3, based on sector data from GTM Research and SEIA (2018) and racking type estimated from Weinshenker (2017).

Table 3. U.S. PV System Installations by Sector and Racking Type, 2017

\begin{tabular}{|c|c|c|c|c|}
\hline & $\begin{array}{l}\text { Utility } \\
\text { (295-W } \\
\text { modules) }\end{array}$ & $\begin{array}{l}\text { Commercial } \\
\text { (295-W } \\
\text { modules) }\end{array}$ & $\begin{array}{l}\text { Residential } \\
\text { (260-W } \\
\text { modules) }\end{array}$ & Total \\
\hline Single-axis tracker & $5 \mathrm{GW}$ & $0.1 \mathrm{GW}$ & -- & $5.1 \mathrm{GW}$ \\
\hline Fixed tilt & $1.2 \mathrm{GW}$ & $0.9 \mathrm{GW}$ & -- & $2.1 \mathrm{GW}$ \\
\hline $\begin{array}{r}\text { Rooftop } \\
\text { (includes low-slope and } \\
\text { carport racking) }\end{array}$ & -- & $1.1 \mathrm{GW}$ & $2.2 \mathrm{GW}$ & $3.3 \mathrm{GW}$ \\
\hline Total & $6.2 \mathrm{GW}$ & $2.1 \mathrm{GW}$ & $2.2 \mathrm{GW}$ & $10.5 \mathrm{GW}$ \\
\hline
\end{tabular}

Figure 15 shows historical and projected PV deployment by installation type for the United States since 2010. Since 2012, more than half of installations have occurred in the utility-scale sector, which is projected to lead the market through 2021, but growth is expected in all sectors. The residential sector began to exceed the commercial sector in 2014 , and this trend is projected to continue. Overall, use of both aluminum and steel racking is likely to continue growing. 


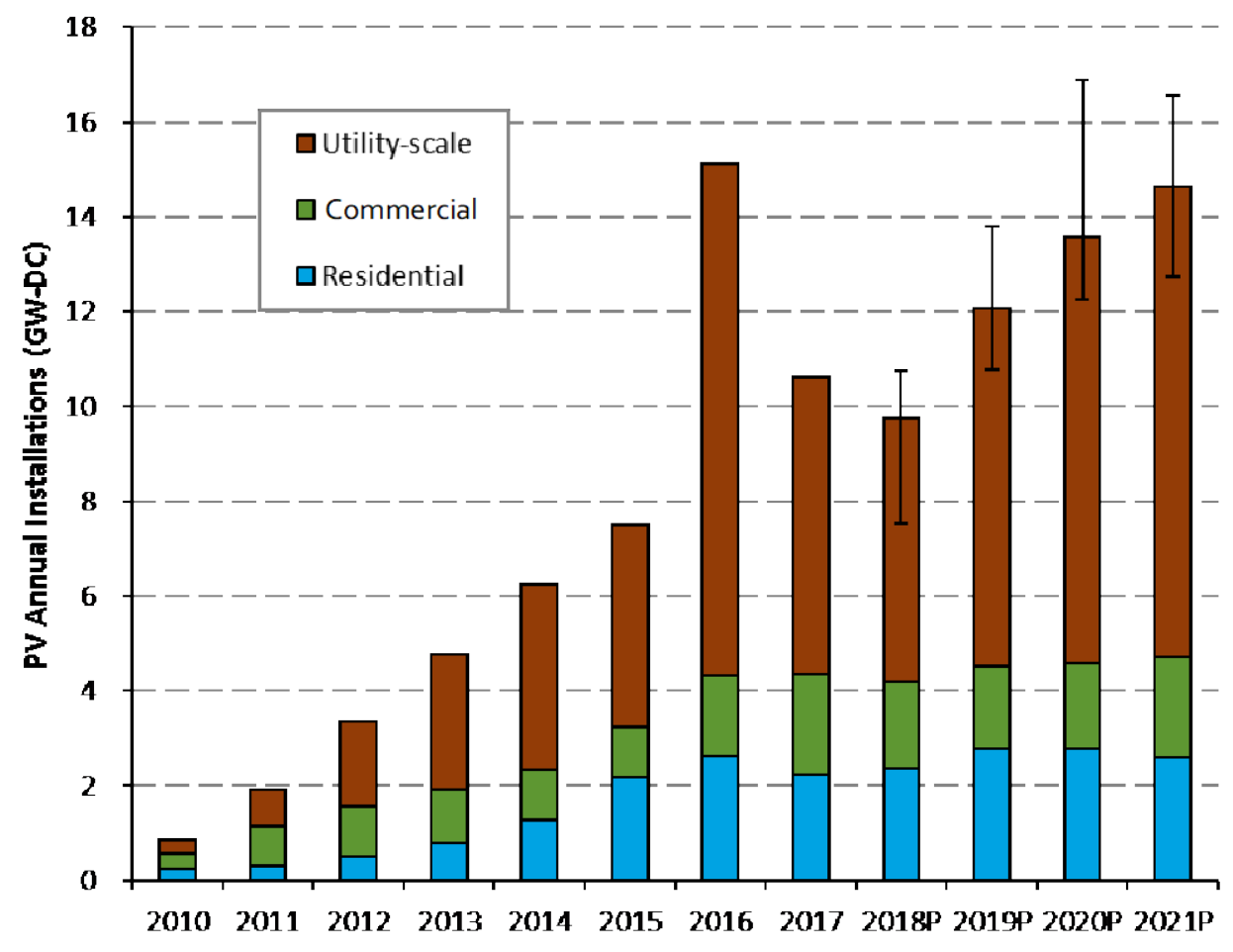

Note: $\mathrm{P}=$ projection. Bar represents median projection. Error bars represent high/low projections.

Figure 15. Annual historical and projected installations of U.S. PV, 2010-2021 (BNEF 2018), (Goldman Sachs 2018), (GTM Research and SEIA 2018), (IHS 2018), (Deutsche Bank AG 2018)

The cost and mass breakdowns of the different PV system types are shown in Figure 16, assuming c-Si modules. This figure assumes all module costs are $\$ 0.35 / \mathrm{W}$ as reported in Fu et al. (2017). The values are based on material costs only and do not include installation labor or other softs costs occurring at the system level, such as permitting. Specific pricing and mass details are reported in the appendix, largely estimated from Fu et al. (2017), Woodhouse et al. (2019), and Michael and Selvarasan (2017) except where noted throughout this section. Module components are typically shown on the right side of the pie chart, while system components appear on the left. The electrical BOS components include cables, switchgears, panel boards, onsite transmission, and so forth. Structural components other than steel or aluminum racking have been omitted, because their cost and mass are both less than $1 \%$ of the totals.

Given the high cost and mass of steel and aluminum necessary for any installation type, we examine the supply chains for both materials. The remaining highest-cost components are inverters, glass, and the polymers EVA and Tedlar (the most common backsheet material), which we examine in that order. We do not examine silicon cells and silver metallization, because they are studied in detail elsewhere (Redlinger, Eggert, and Woodhouse 2016, Woodhouse et al. 2019, Sandor et al. 2018).

Thin-film PV. The cost and mass breakdowns of non-silicon modules, specifically thin-film PV such as CdTe and CIGS modules, differ significantly from Figure 16. Because 2017 U.S. production was roughly $116 \mathrm{MW}$ for CIGS modules and $175 \mathrm{MW}$ for CdTe modules (GTM Research and SEIA 2018), domestically made thin-film modules correspond to roughly $3 \%$ of 2017 U.S. PV installations. This is a lower share of the market than usual, because the CdTe PV 
manufacturer First Solar was retooling to upgrade its product offerings (GTM Research and SEIA 2018). For example, in 2015 and 2016, thin-film module production represented 8\% and $4 \%$ of U.S. installations, respectively (GTM Research and SEIA 2017). To be consistent with the rest of the 2017 data used in this report, 2017 thin-film production numbers are used even though this year represents a smaller percentage of the market than usual.

An estimation of system costs for thin-film modules has been constructed based on Horowitz, Fu, and Woodhouse (2016) and Woodhouse et al. (2013). These modules are frameless, use two sheets of glass, and do not use a backsheet. Based on module area and efficiency data in Horowitz, Fu, and Woodhouse (2016), we assume CIGS modules have a power rating of $150 \mathrm{~W}$, and CdTe modules have a power rating of $115 \mathrm{~W}$. Therefore, CIGS modules are assumed to use $102 \mathrm{~kg}$ of flat glass per $\mathrm{kW}(\$ 46 / \mathrm{kW})$, while CdTe uses $86 \mathrm{~kg} / \mathrm{kW}(\$ 40 / \mathrm{kW})$, where the front and back glass are of different thickness and reported costs do not include coatings. Given that thinfilm modules only use one layer of EVA (silicon modules use two), we assume a material intensity of $0.4 \mathrm{~kg}$ EVA per $\mathrm{m}^{2}$ estimated from Michael and Selvarasan (2017) and a cost of $\$ 1.6 / \mathrm{m}^{2}$ based on Woodhouse et al. (2019). This corresponds to $2.9 \mathrm{~kg} / \mathrm{kW}(\$ 11.60 / \mathrm{kW})$ for CIGS modules and $2.5 \mathrm{~kg} / \mathrm{kW}(\$ 10 / \mathrm{kW})$ for CdTe modules. Finally, we assume steel racking is used for all thin-film modules. The steel mass intensity is estimated to be $15.9 \mathrm{~kg} / \mathrm{m}^{2}$ of PV modules, or $\$ 26 / \mathrm{m}^{2}$ based on the model developed for $\mathrm{Fu}$ et al. (2017). This corresponds to 116 $\mathrm{kg} / \mathrm{kW}(\$ 190 / \mathrm{kW})$ for CIGS modules and $100 \mathrm{~kg} / \mathrm{kW}(\$ 163 / \mathrm{kW})$ for CdTe modules. Because these material intensities do not differ excessively from silicon module racking steel intensities (roughly $95 \mathrm{~kg} / \mathrm{KW}$ ), we do not include a separate racking analysis for these modules.

This section primarily considers the infrastructure availability of the United States to meet demand in industries upstream of PV manufacturing if all U.S. PV installations were to be manufactured domestically and constructed from domestically sourced materials and components. It does not evaluate economic factors such as cost-competitiveness with other countries, policy incentives, shipping costs, and so forth, which are important factors to evaluate but are outside the scope of this work. The goal of this work is to assess the current state of the industries and delineate the infrastructure challenges and opportunities the upstream U.S. manufacturing sectors could encounter if the U.S. PV manufacturing sector grows, which is expected to occur given multiple announcements of new planned U.S. PV manufacturing facilities. 


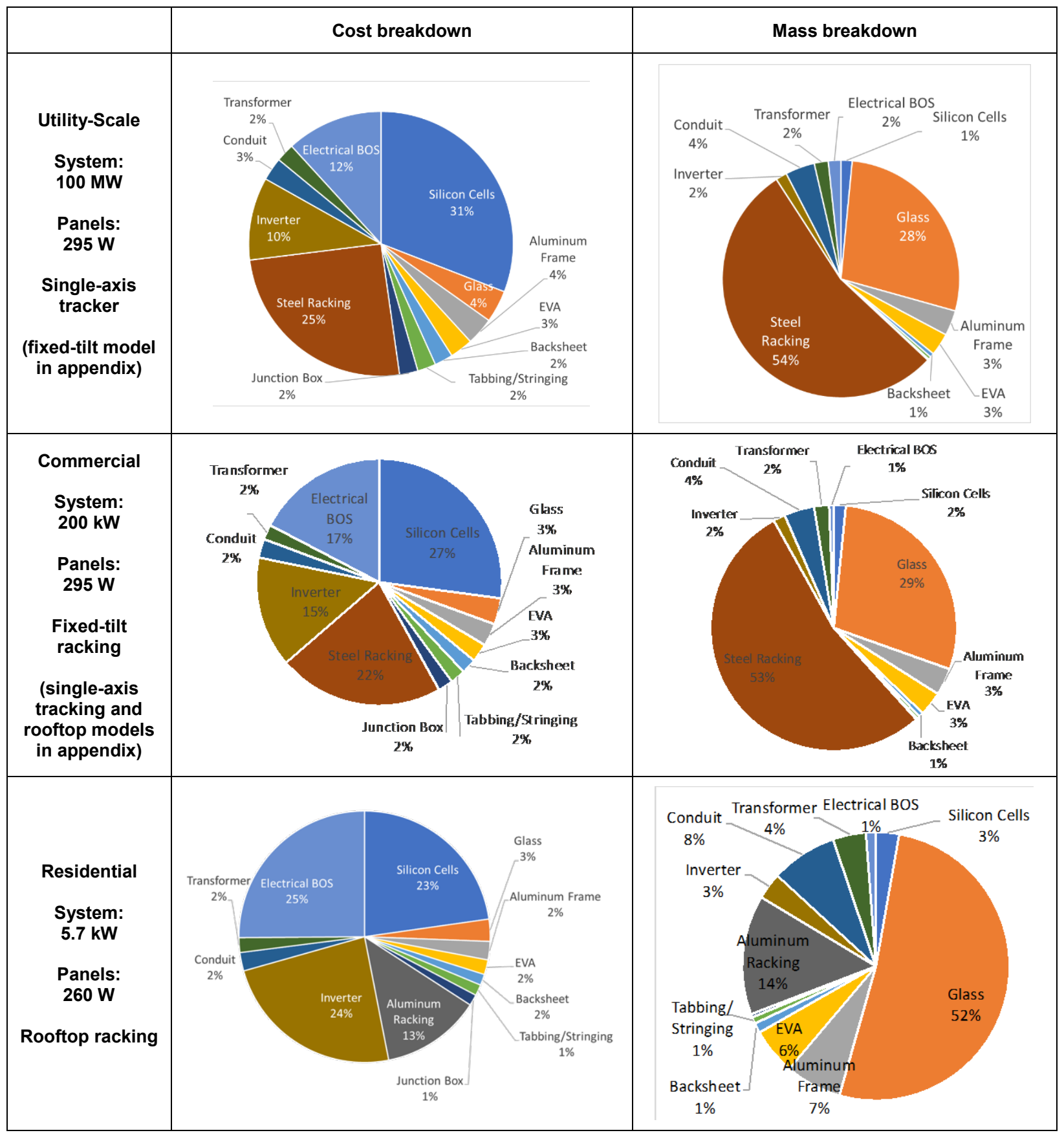

Figure 16. Material/component contributions of utility-scale, commercial, and residential PV systems to cost (left column) and mass (right column)

\subsection{Steel}

In the PV industry, steel is primarily used for racking in ground-mounted utility-scale and commercial PV systems. A small amount of steel is used in other components, but here we focus on steel used for utility-scale PV racking structures. There are multiple reasons why producing steel for PV systems in the United States might make sense. First, steel is dense, and thus shipping it over long distances is relatively expensive. Second, manufacturing steel is energy intensive, which gives a potential cost advantage to the United States, which has lower energy 
costs compared to many other countries. Local investment relationships and U.S. content requirements might also be factors that could increase domestic supply of steel for PV racking. However, at the time of this study, it is unclear what fraction of steel PV racking uses domestically sourced steel.

The global distribution of 2017 steel production is shown in Figure 17 for the top 13 producing countries, which cumulatively accounted for $87 \%$ of total global steel production in 2017 . The total amount of steel produced globally in 2017 is estimated to be 1,700 million MT. China was the largest steel producer in 2017, accounting for 843 million MT or 50\% of global production. India and Japan were the second and third top steel producers in 2017, accounting for 203 million MT or $12 \%$ of global production. The United States was the fourth largest producer with 82 million MT or 5\% of global production (U.S. Geological Survey 2018). Raw steel production in the United States has remained around 80 million MT/year after recovering from the 2009 recession, prior to which annual U.S. steel production had been consistently above 90 million MT/year since 1994 (U.S. Geological Survey 2018, 2013, 2008, 2003, 1998).

Within the United States, steel capacity in 2017 was concentrated in the Midwest (Figure 18), where the top three states with the greatest production (Indiana, Ohio, and Michigan) accounted for roughly half of 2017 U.S. steel production (U.S. Geological Survey 2018). In 2017 and 2018, steel capacity was operating between $70 \%$ and $80 \%$ utilization, which is an improvement over prior years but still below the utilization rates before the 2008 recession (NASDAQ 2018, National Public Radio 2019). Although some primary steel production exists, most U.S. steel production occurs at mini mills that generate secondary steel from scrap. Of the 110 U.S. mini mills existing in 2010, 45\% were in Indiana, Ohio, Michigan, and Pennsylvania (AIM Market Research 2010). The shift to mini mills over the last half century has enabled steel components to be produced in a larger range of locations beyond the Midwest (Worstall 2016). This represents a significant advantage over the previous mode of steel production at larger plants, in that locating production close to consumption greatly reduces shipping costs (Anderton 2015). 


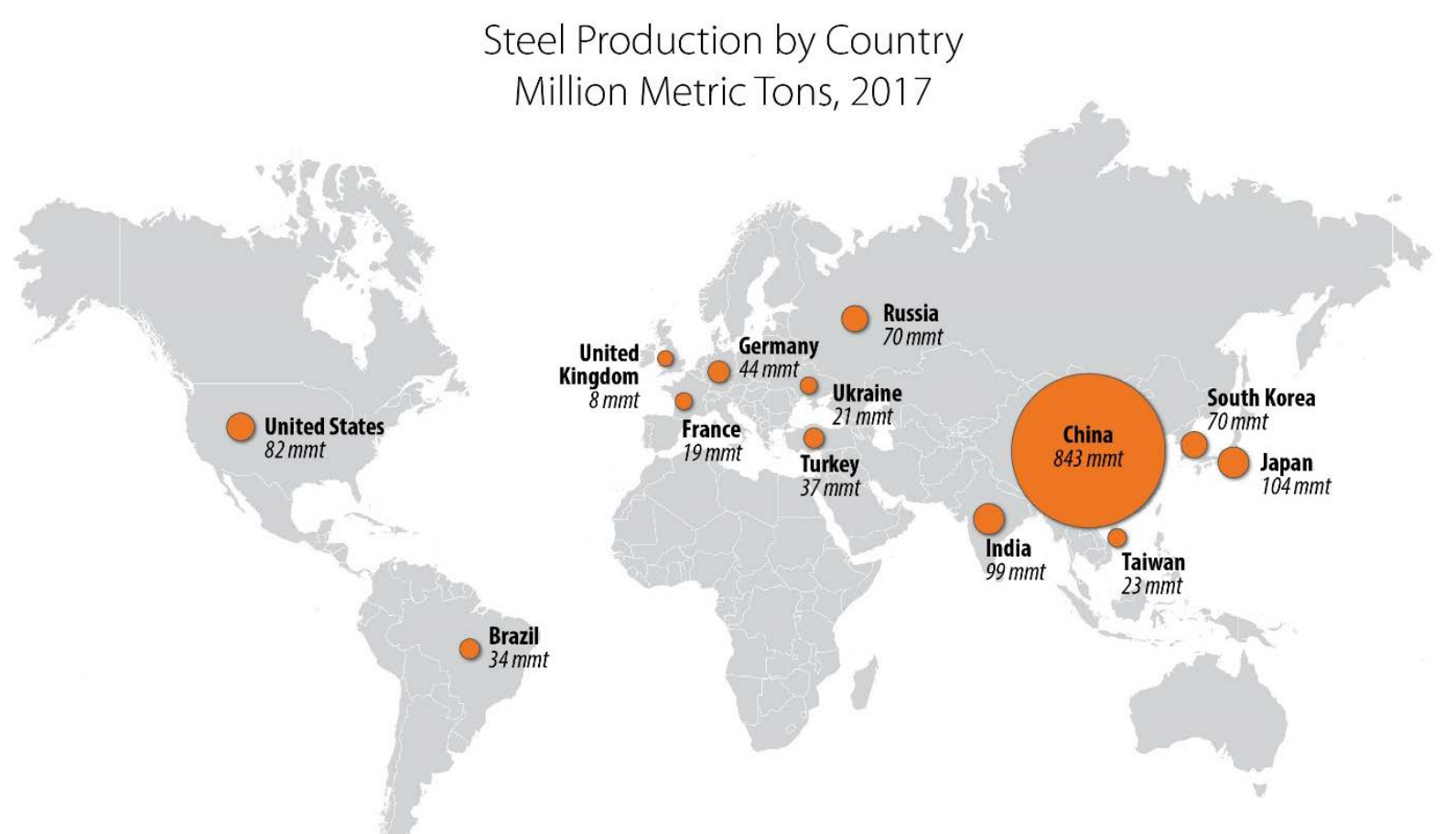

Figure 17. Global steel production in 2017, constructed from data in U.S. Geological Survey (2018)

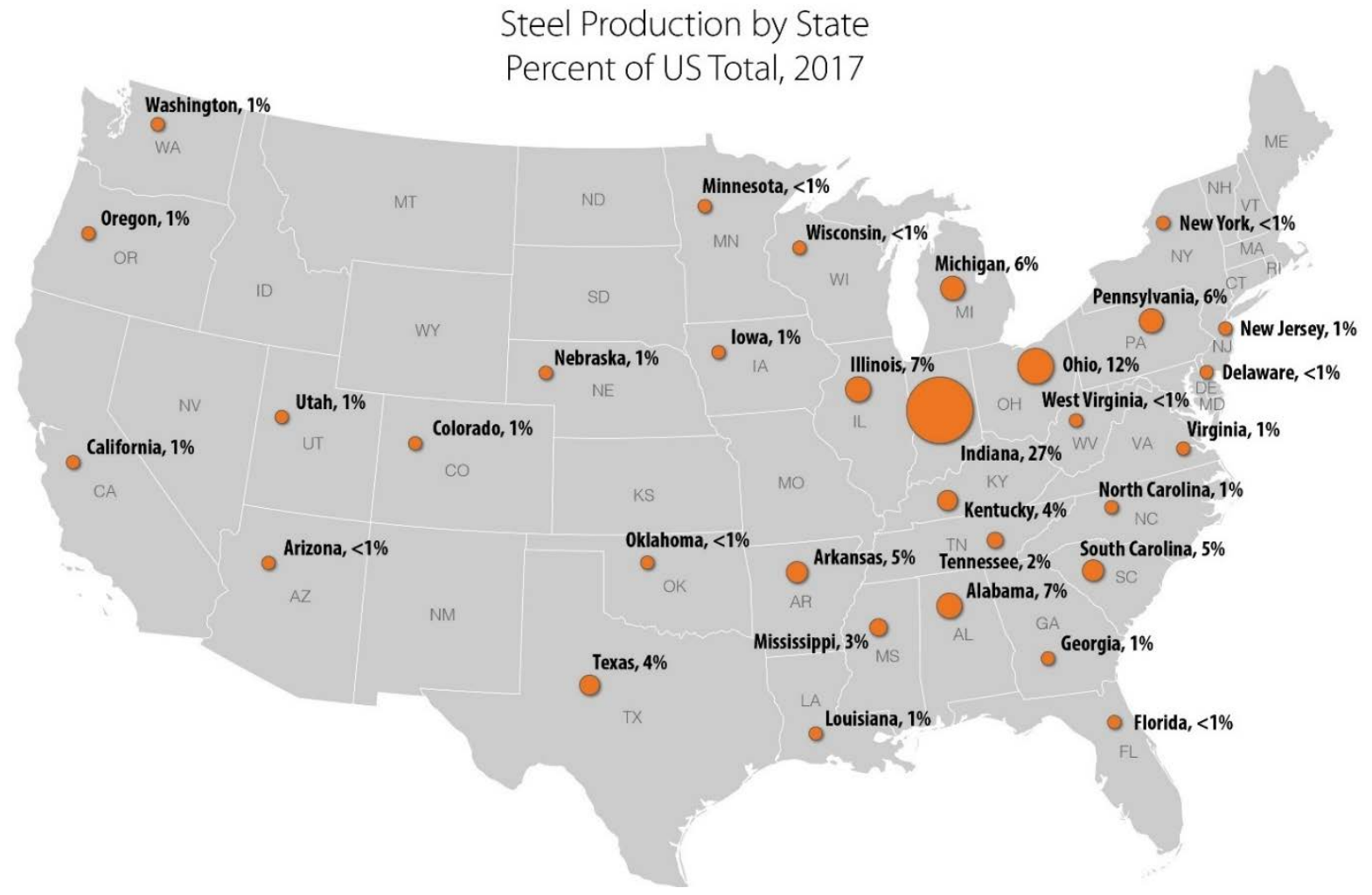

Figure 18. U.S. steel capacity in 2017, estimated from data in U.S. Geological Survey (2018) and AIM Market Research (2010) 
In 2017, domestic steel production in the United States accounted for $70 \%$ of demand (by weight), as shown in Figure 19. The remaining 30\% of demand was met by imports, where approximately half of imports originated from four countries: Canada, Brazil, South Korea, and Mexico. Domestic consumption accounted for $85 \%$ of demand, while exports accounted for $9 \%$ and stockpiling accounted for $6 \%$. In terms of end-use markets, $28 \%$ of U.S. steel shipments in 2017 went to warehouses/steel service centers, followed by $20 \%$ to construction and $17 \%$ to transportation applications.

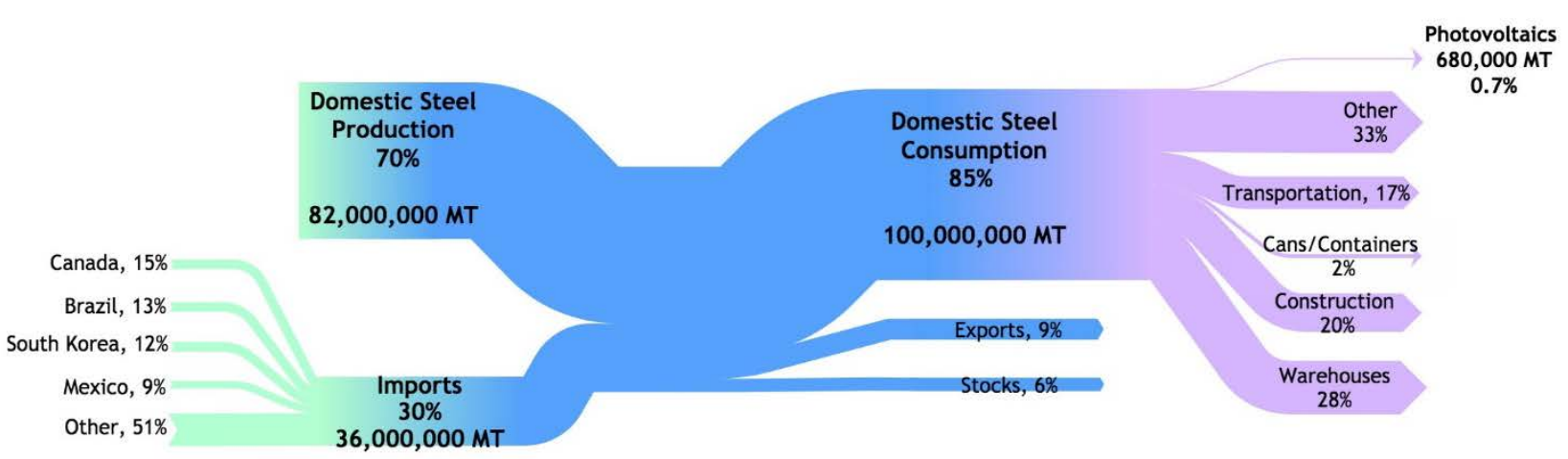

Figure 19. U.S. steel consumption in 2017 by input and end use, constructed from data in U.S. Geological Survey (2018)

To estimate the fraction of steel consumption attributed to PV installations, we assume all ground-mounted PV was constructed of steel. We assume an average mass of $27.1 \mathrm{~kg}$ of steel for fixed-tilt racking per $295-\mathrm{W}$ module, and $28.3 \mathrm{~kg}$ of steel for single-axis tracking per $295-\mathrm{W}$ module, based on the model developed in Fu et al. (2017). We then scale these numbers by the corresponding 2017 U.S. installations for each racking type to calculate total PV steel domestic consumption. The data from Table 3 indicate that $5.1 \mathrm{GW}$ of single-axis trackers and $2.1 \mathrm{GW}$ of fixed-tilt PV correspond to approximately 680,000 MT of steel used for PV systems in the United States in 2017. Thus, we estimate that PV accounted for less than 1\% of total U.S. steel consumption in 2017.

These data are reported in Table 4 along with global PV steel consumption. Globally, an estimated 78 GW of non-rooftop PV were installed in 2017 (Attia, Parikh, and Heggarty 2017). Using a weighted average of $28 \mathrm{~kg}$ of steel per $295-\mathrm{W}$ module, this corresponds to approximately 7.4 million MT of steel in 2017 for global PV installations, which is $0.4 \%$ of 2017 global steel consumption.

Table 4. Global and Domestic Steel Consumption Compared to PV Steel Consumption in 2017

\begin{tabular}{|r|c|c|}
\hline \multicolumn{2}{|c}{ Total } & PV Only \\
\hline Global & $1,700,000,000 \mathrm{MT}$ & $\begin{array}{c}7,400,000 \mathrm{MT} \\
(0.4 \% \text { of global })\end{array}$ \\
\hline Domestic & $\begin{array}{c}100,000,000 \mathrm{MT} \\
(6 \% \text { of global })\end{array}$ & $\begin{array}{c}680,000 \mathrm{MT} \\
(0.7 \% \text { of domestic })\end{array}$ \\
\hline
\end{tabular}

Given that racking is the primary end use for steel in the PV industry, we also examine what companies produce racking for PV; the most recent data available are for 2016. In Table 5, we 
report the major ground-mounted PV racking producers based in the United States and their total 2016 production (in MW of PV). Total production corresponded to $11.4 \mathrm{GW}$ (Weinshenker 2017), while 10.6 GW of utility-scale PV and 1.6 GW of commercial PV were installed in 2016 (GTM Research and SEIA 2017). Given that roughly half of the commercial PV was groundmounted (which we assume used steel racking, although a small fraction may be aluminum), we conclude that the United States was self-sufficient in steel racking for PV.

In Table 6, we report major global PV steel tracker producers and their total production in 2017. Four of these are based in the United States (noted in bold), including the top two producers (Moskowitz 2018). However, tracker vendors often have multiple manufacturing locations. Although we have not mapped specific manufacturing locations, this information illustrates that U.S. firms have been playing a key role in PV tracking.

Based on our estimates of global and domestic steel consumption for PV, in 2017 total steel production far exceeded the demand for steel in PV systems. Although it is unknown what fraction of PV racking is supplied by imported steel, on an aggregate basis the United States has sufficient production capacity to meet its own demand for steel PV racking. Going forward, as the U.S. PV industry continues to grow, there are two implications from our analysis: 1) the PV industry could serve as a catalyst for growth in domestic steel production, and 2) the PV industry is not likely to encounter significant supply constraints with respect to steel.

Table 5. U.S. Ground-Mount Racking Shipments by Company in 2016, Constructed from Weinshenker (2017)

\begin{tabular}{|r|c|}
\hline Company & $\mathbf{2 0 1 6}$ \\
\hline MWdc
\end{tabular}

\section{Table 6. Global PV Tracker Shipments by Company in 2017, constructed from Moskowitz (2018)}

\begin{tabular}{|r|c|}
\hline Company (U.S. Bold) & $\begin{array}{c}\mathbf{2 0 1 6} \\
\text { MWdc }\end{array}$ \\
\hline NEXTracker & 4,800 \\
\hline Array Technologies & 2,000 \\
\hline Soltec & 1,000 \\
\hline Arctech Solar & 870 \\
\hline Convert Italia & 730 \\
\hline PV Hardware & 730 \\
\hline STi Norland & 580 \\
\hline Nclave & 580 \\
\hline Scorpius Tracker & 580 \\
\hline Ideematec & 440 \\
\hline Solar Steel & 440 \\
\hline SunPower & 440 \\
\hline Mahindra Susten & 440 \\
\hline
\end{tabular}

\subsection{Aluminum}

Photovoltaic production uses aluminum in module frames, rooftop racking, cabling, power electronics housing, and miscellaneous components. Aluminum is used in residential and commercial rooftop systems due to its electrical conductivity, strength, and relatively low 
weight. For the purposes of our study, we focus on module frames and racking, because they are the most aluminum-intensive components. Viable substitute materials exist for these components, but aluminum is preferred because of its lifetime performance, corrosion resistance, low weight, and low cost. Although we evaluate the domestic aluminum industry in the context of aluminum PV racking production, at the time of this study it is unclear what fraction of aluminum PV racking uses domestically sourced aluminum.

The global distribution of primary aluminum production in 2017 is shown in Figure 20 for the top 12 producing countries, which cumulatively accounted for $87 \%$ of total global aluminum production in 2017. The total amount of aluminum produced globally in 2017 was about 60 million MT. China was the top producer, accounting for $54 \%$ of the global total in 2017 . The next two closest countries were Russia and Canada, which each produced roughly $5 \%-6 \%$ of the global total.

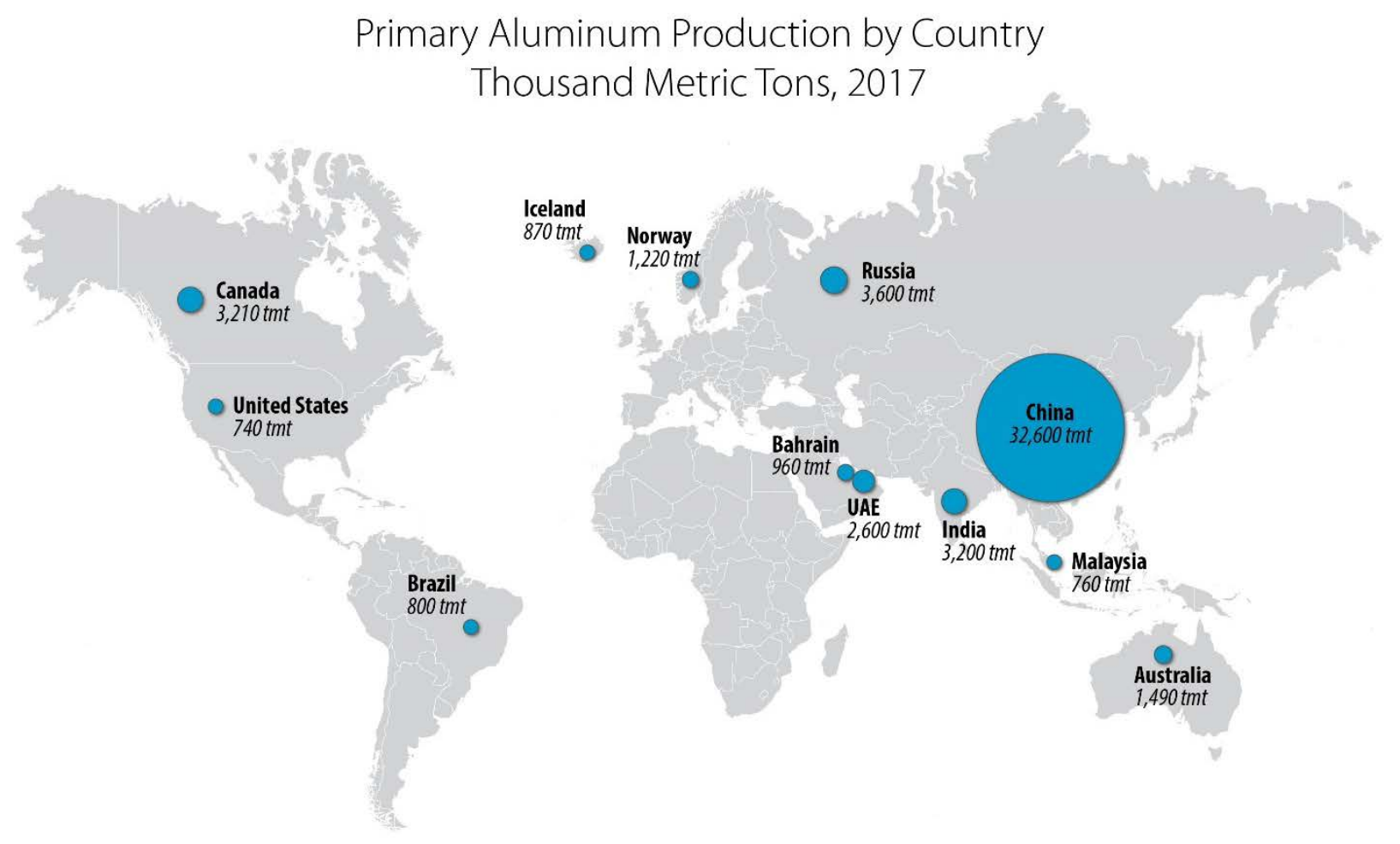

Figure 20. Global production of primary aluminum in 2017, constructed from data in U.S. Geological Survey (2018)

The United States was the twelfth-largest producer, with 740,000 MT or $1.2 \%$ of global production in 2017, which marks the first year in recent history when the United States was not in the top 10 countries for primary aluminum production (U.S. Geological Survey 2018). Primary aluminum production in the United States declined 64\% between 2012 and 2017, and in 2017 was at its lowest level since 1951. The U.S. primary aluminum smelting capacity in 2017 is shown in Figure 21. Half of the smelting capacity was located in Kentucky and nearby states. Only five of the eight U.S. primary aluminum smelters were operational in 2017 (three of these five were functioning at reduced capacity). The remaining three were on standby throughout the year. This excess capacity represents an opportunity for expanded U.S. aluminum production. 
The United States consumed approximately 6 million MT (10\%) of global aluminum production in 2017, which greatly exceeded the proportion of global aluminum produced in the United States (U.S. Geological Survey 2018). In 2017, $72 \%$ of U.S. aluminum consumption came from imports, followed by secondary aluminum production $(19 \%)$ and primary aluminum production $(9 \%)$, as shown in Figure 22. More than half of imports were sourced from Canada, followed by $8 \%$ from Russia and the remainder in smaller fractions from other countries. Domestic consumption accounted for $68 \%$ of demand, while the remainder went to exports. The main enduse applications for aluminum consumed in the United States were the transportation sector (41\%), followed by packaging (20\%) and buildings (14\%), with electrical applications, machinery, and consumer durables making up a significant portion of the remainder.

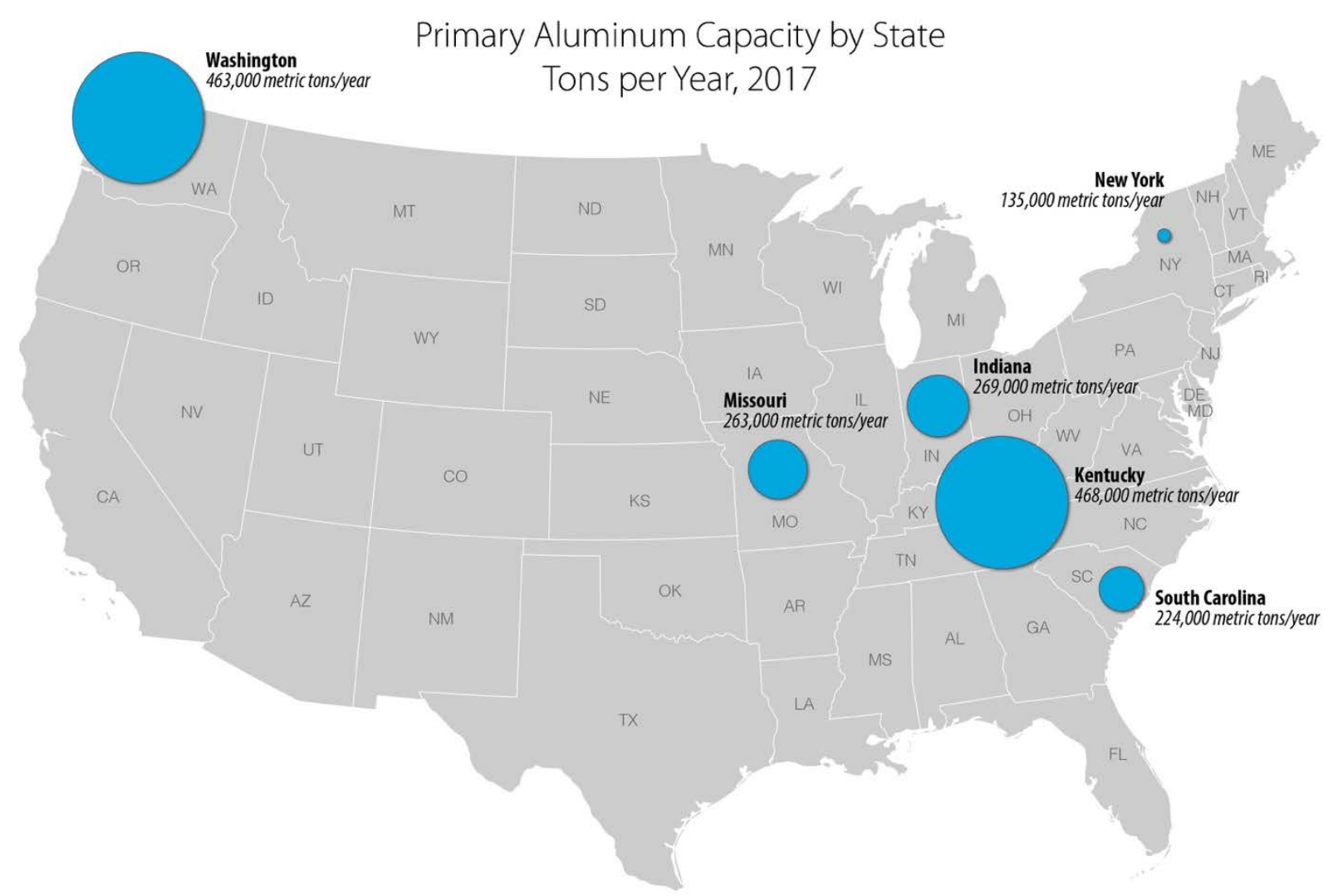

Figure 21. 2017 U.S. primary aluminum capacity in MT, constructed from data in U.S. Geological Survey $(2018,2017)$

To estimate the fraction of aluminum consumed by the PV industry, we assume a mass of $3.6 \mathrm{~kg}$ of aluminum per $260-\mathrm{W}$ module for residential rooftop racking, $4.1 \mathrm{~kg}$ of aluminum per $295-\mathrm{W}$ module for commercial rooftop racking, $1.7 \mathrm{~kg}$ of aluminum used in the frame of a $260-\mathrm{W}$ module, and $1.8 \mathrm{~kg}$ of aluminum used in the frame of a $295-\mathrm{W}$ module. These estimates are based on Michael and Selvarasan (2017), which reports aluminum frames to be $10 \%$ of module mass, and Fu et al. (2017), in which pricing indicates that aluminum racking corresponds to 14 $\mathrm{kg} / \mathrm{kW}$. We then scale these masses by the corresponding installation amounts, as reported in Table 3, and sum them. We assume that all rooftop racking is constructed from aluminum, although there may be a small fraction constructed from steel. Thus, we estimate that 
approximately 110,000 MT of aluminum were consumed by the U.S. PV industry in 2017, which represents $1.8 \%$ of total domestic aluminum consumption in 2017 . Given that most modules in 2017 were imported, it is likely that most of the aluminum in module frames was imported. With respect to racking, it is likely that aluminum racking installed in the United States was produced domestically but constructed from imported aluminum.

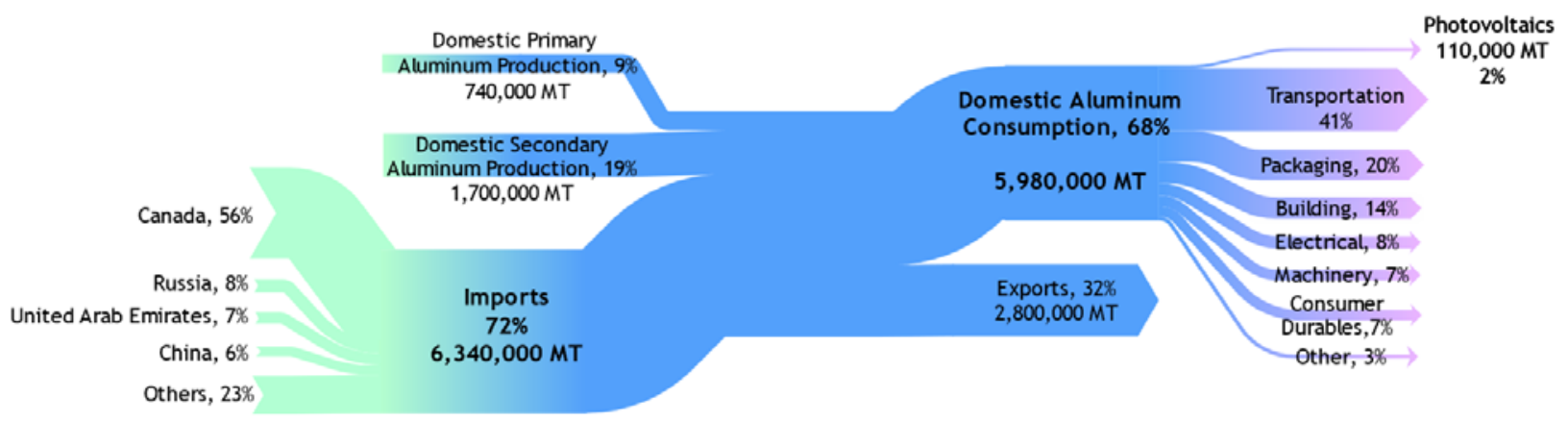

Figure 22. U.S. aluminum consumption in 2017 by input and end use, constructed from data in U.S. Geological Survey (2018)

Table 7 presents U.S. and global total and PV-related consumption of aluminum. Global PV aluminum consumption was calculated based on $21 \mathrm{GW}$ of global rooftop PV installations in 2017 as reported in Attia, Parikh, and Heggarty (2017) and assuming they were exclusively 260$\mathrm{W}$ modules. The remaining $78 \mathrm{GW}$ (non-rooftop PV) were assumed to be $295-\mathrm{W}$ modules. These installation sizes were then scaled by the corresponding aluminum frame and racking mass assumptions defined in the previous paragraph. The sum of all aluminum frames and racking mass equals approximately $870,000 \mathrm{MT}$ of aluminum consumed in the global PV industry in 2017 , which corresponds to $1.5 \%$ of global aluminum consumption. Thus, our analysis indicates that, even with significant growth in PV demand, both global and domestic capacity would be more than sufficient to meet aluminum production needs.

Table 7. Global and Domestic Aluminum Consumption Compared to PV Aluminum Consumption in 2017

\begin{tabular}{|c|c|c|c|c|}
\hline & Total & PV Module Frames & PV Racking & PV Total \\
\hline Global & $60,000,000 \mathrm{MT}$ & $\begin{array}{c}610,000 \mathrm{MT} \\
\text { (1\% of global) }\end{array}$ & $\begin{array}{c}260,000 \mathrm{MT} \\
(0.4 \% \text { of global })\end{array}$ & $\begin{array}{c}870,000 \mathrm{MT} \\
\text { (1.5\% of global) }\end{array}$ \\
\hline Domestic & $\begin{array}{c}5,980,000 \mathrm{MT} \\
(10 \% \text { of global) }\end{array}$ & $\begin{array}{c}65,000 \mathrm{MT} \\
\text { (1.1\% of domestic) }\end{array}$ & $\begin{array}{c}44,000 \mathrm{MT} \\
\text { (0.7\% of domestic) }\end{array}$ & $\begin{array}{c}110,000 \mathrm{MT} \\
\text { (1.8\% of domestic) }\end{array}$ \\
\hline
\end{tabular}

Given that racking is a major end use for aluminum in the PV industry, it is important to identify the companies producing racking for PV. The latest data available are from 2016. Table 8 reports major aluminum PV racking producers based in the United States and their total production (in MW of PV) in 2016, based on data available in Weinshenker (2017). We estimate that the total amount of aluminum racking produced in the United States in 2016 was sufficient to install 3.45 GW of PV systems. This level of production roughly equals the $3.4 \mathrm{GW}$ of U.S. rooftop PV installations in 2016 (GTM Research and SEIA 2017). 
Detailed data on global production of aluminum racking are not readily available. However, based on our estimates of global and U.S. consumption of aluminum for PV racking in Table 7, it is clear that total 2017 aluminum production far exceeded the demand for aluminum in PV systems. Although it is unclear what fraction of U.S. aluminum racking is supplied by imported aluminum, PV demand for aluminum only represents $6 \%$ of domestic aluminum production (both primary and secondary). Because U.S. primary aluminum capacity is currently significantly underutilized, the United States has sufficient production capacity to meet its own demand for aluminum PV racking and frames. Going forward, as the U.S. PV industry continues to grow, there are two implications from our analysis: 1) growth in the PV industry could occupy currently idle primary aluminum production capacity, and 2) the PV industry is not likely to encounter significant supply constraints with respect to aluminum.

Table 8. U.S. Rooftop Racking Shipments in 2016, Constructed from Weinshenker (2017)

\begin{tabular}{|r|c|}
\hline Company & $\begin{array}{c}2016 \\
\text { MWdc }\end{array}$ \\
\hline SunPower & 640 \\
\hline SolarCity & 550 \\
\hline SnapNrack & 470 \\
\hline UniRac & 430 \\
\hline Iron Ridge & 360 \\
\hline Ecolibrium & 180 \\
\hline PanelClaw & 200 \\
\hline Everest & 130 \\
\hline SunModo & 80 \\
\hline Ten K & 65 \\
\hline Schletter & 55 \\
\hline Pegasus & 50 \\
\hline GameChange & 40 \\
\hline AeroCompact & 30 \\
\hline Total (including others not listed) & 3,450 \\
\hline
\end{tabular}

\subsection{Inverters}

Inverters are a standard part of PV systems, serving a number of functions including converting the direct current output of PV modules into alternating current. Many types of inverters serve different PV system configurations. The two most common are three-phase string inverters and central standalone inverters, which account for more than half of PV installations (Moskowitz 2017). The remainder either use single-string inverters, central solution inverters, or microinverters. For the purposes of this analysis, we categorize all inverters together and mainly report quantities in monetary value, although MW units are used where appropriate.

Global inverter consumption (sales) totaled about $\$ 64$ billion in 2017 (IMARC 2018). In 2015, the major inverter end-use applications were roughly (by value) $40 \%$ for motors, $20 \%$ for uninterruptible power supplies (UPS), $15 \%$ for PV, $10 \%$ for rail, $10 \%$ for wind power, and $5 \%$ for electric/hybrid vehicles (Yole Développement 2016). However, these markets are changing rapidly, and growth in $\mathrm{PV}$ installations indicates that $\mathrm{PV}$ is becoming a significant driver in the 
broader inverter market. The global PV inverter market was valued at \$6.3 billion in 2017 (Zipp 2018). A non-exhaustive list of global PV inverter manufacturers and the countries in which they are known to have manufacturing facilities is shown in Table 9 (Solar Power World 2019). Assuming an inverter loading ratio of 1.25 watts direct current/watts alternating current (Wdc/Wac) based on a weighted average of residential/commercial versus utility-scale PV from $\mathrm{Fu}$, Margolis, and Feldman (2018), $79.2 \mathrm{GWac}$ of inverters were necessary for the $99 \mathrm{GWdc}$ of PV installed globally in 2017. These data, along with the global PV inverter market size, suggest a rough average global $\mathrm{PV}$ inverter cost of $\$ 80$ million/GWac.

Table 9. Select Global PV Inverter Manufacturers, Constructed from Solar Power World (2019)

\begin{tabular}{|r|c|}
\hline Company (HQ) & Manufacturing Locations \\
\hline ABB (Switzerland) & India, Italy \\
\hline Alencon Systems (U.S.) & U.S. \\
\hline APsystems (China) & China \\
\hline Chilicon Power (U.S.) & U.S. \\
\hline Chint Power Systems (U.S.) & China, U.S. \\
\hline Enphase Energy (U.S.) & China, Mexico \\
\hline Fronius USA (U.S.) & Austria \\
\hline Ginlong Solis (China) & China \\
\hline Huawei (China) & China \\
\hline Ingeteam (Spain) & Brazil, India, Spain, U.S. \\
\hline Morningstar (U.S.) & Taiwan \\
\hline Outback Power Technologies (U.S.) & China, U.S. \\
\hline Pika Energy (U.S.) & U.S. \\
\hline SMA (Germany) & Germany \\
\hline Sol-Ark (U.S.) & China, U.S. \\
\hline Sungrow Power Supply (China) & China, India \\
\hline Tabuchi Co. of America Ltd (U.S.) & Japan, Thailand \\
\hline Tigo Energy (U.S.) & China \\
\hline Yaskawa Solectria Solar (U.S.) & China, U.S. \\
\hline
\end{tabular}

Based on the $\$ 80$ million/GWac inverter cost estimate, the United States consumed about $\$ 670$ million (10.5 GWdc, 8.4 GWac) worth of PV inverters as a result of PV installations in 2017. Assuming that $\$ 670$ million represents $15 \%$ of domestic inverter consumption as estimated from Yole Développement (2016), total U.S. inverter consumption in 2017 was equivalent to about $\$ 6.7$ billion. Data from the U.S. International Trade Commission (2017) for HTS code 8504.40.9570 indicate the United States imported \$1.42 billion in inverters in 2017, and it exported \$360 million (Figure 23). Of the imports, 37\% came from China, 18\% from Japan, and $17 \%$ from Germany. All other countries contributed less than $8 \%$ each to the import total. Given the inverter import and export values, 2017 domestic inverter production should be roughly equivalent to $\$ 3.5$ billion. However, due to the significant assumptions required to make these estimates, the values shown in Figure 23 may not reflect the 2017 inverter market with a high degree of accuracy. Table 10 summarizes the estimates for U.S. and global inverter consumption as well as PV-related consumption of inverters. 


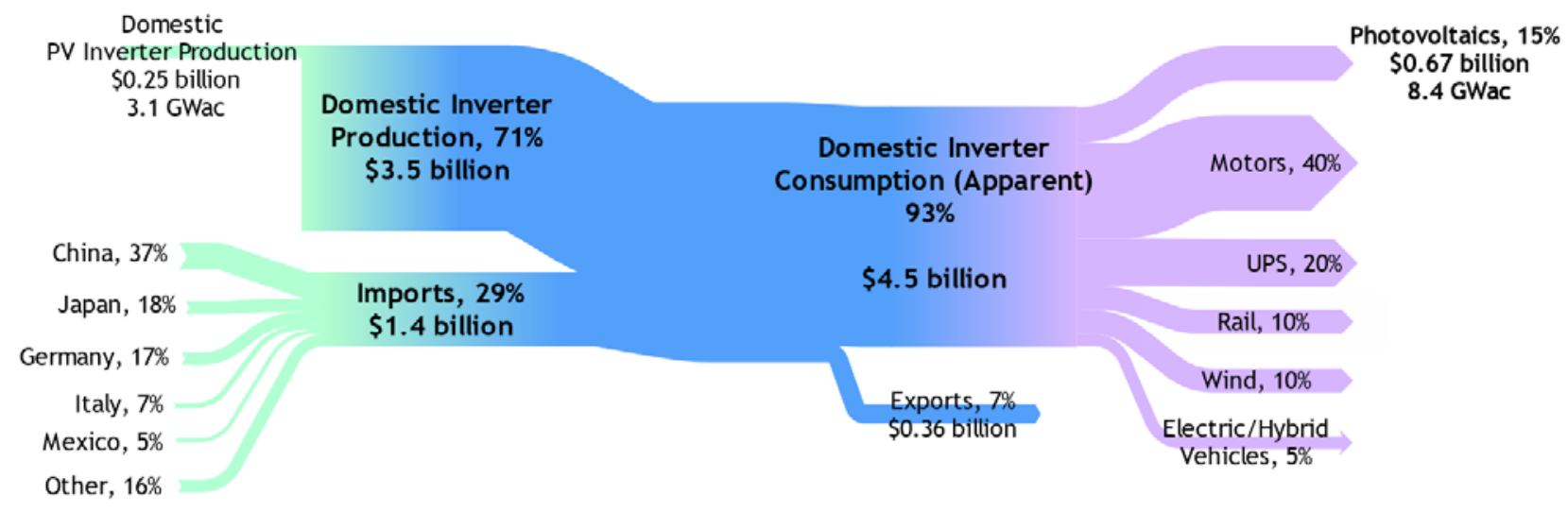

Figure 23. U.S. inverter consumption in 2017 by input and end-use

Table 10. Global and Domestic Inverter Consumption in 2017 Compared to PV Inverter Consumption

\begin{tabular}{|c|c|c|}
\hline & Total & PV Only \\
\hline Global & $\$ 64,000,000,000$ & $\begin{array}{l}\$ 6,300,000,000 \\
(10 \% \text { of global) }\end{array}$ \\
\hline Domestic & $\begin{array}{c}\$ 4,500,000,000 \\
\text { (7\% of global) }\end{array}$ & $\begin{array}{c}\$ 670,000,000 \\
\text { (15\% of domestic) }\end{array}$ \\
\hline
\end{tabular}

The largest suppliers of PV inverters in 2017 in the United States are listed in Table 11, while the largest global suppliers of PV inverters in 2017 are shown in Table 12 (country headquarters in parentheses). In both tables, U.S. companies represent a minority of shipments. The United States had approximately 4.3 GWac of PV inverter production capacity in 2017, but only about 3.1 GWac were produced (GTM Research and SEIA 2018). The U.S. PV inverter production capacity peaked near $8 \mathrm{GWac}$ in 2012 but has generally decreased since then. This capacity level would have been adequate to meet current demand given increasing inverter load ratios. The SMA and ABB facilities in the United States closed in 2017, which represented most of the decrease in capacity since 2016 .

PV has begun to account for a significant fraction of U.S. and global inverter production. Now that global demand for PV has reached the scale of $102 \mathrm{GW}$, a dedicated PV inverter supply chain has emerged. As with PV modules, this growth has led to rapid cost declines and technological innovation. Inverter prices are expected to continue falling, which may result in a smaller global market size depending on the rate of PV growth. However, the U.S. market share is expected to increase (Zipp 2018). Imported inverters have captured a growing share of the U.S. PV market over the past couple years. Although current U.S. PV inverter production capacity is insufficient to meet current domestic demand $(8 \mathrm{GWac})$, the United States has historically demonstrated the potential to produce approximately $8 \mathrm{GWac}$, in both 2012 and 2015 (GTM Research and SEIA 2018). Furthermore, as cybersecurity concerns regarding imported power electronics are raised, inverters from trusted suppliers may be increasingly required (Spector 2019). Therefore, as the PV industry grows, it could serve as a catalyst for growing domestic production of PV inverters. 
Table 11. Largest Suppliers of U.S. PV Inverters in 2017, Constructed from Moskowitz (2017)

\begin{tabular}{|r|c|} 
Company (Country Code of HQ) & $\begin{array}{c}\% \text { of } \mathbf{2 0 1 7} \\
\text { U.S. in Bold } \\
\text { quarter }\end{array}$ \\
$\begin{array}{r}\text { SMA (DE) } \\
\text { shipments }\end{array}$ & $21 \%$ \\
\hline Power Electronics (ES) & $20 \%$ \\
\hline SolarEdge Technologies (IL) & $11 \%$ \\
\hline KACO New Energy (DE) & $8 \%$ \\
\hline Chint Power Systems (CN) & $5 \%$ \\
\hline Enphase Energy (U.S.) & $\mathbf{5 \%}$ \\
\hline General Electric (U.S.) & $\mathbf{4 \%}$ \\
\hline Schneider Electric (FR) & $4 \%$ \\
\hline Huawei (CN) & $3 \%$ \\
\hline Yaskawa-Solectria Solar (JP- & $3 \%$ \\
\hline U.S.) & $2 \%$ \\
\hline Ginlong-Solis (CN) & $2 \%$ \\
\hline ABB (CH) & $2 \%$ \\
\hline TMEIC (JP) & $2 \%$ \\
\hline Sungrow Power Supply (CN) & $2 \%$ \\
\hline Delta (TW) & $2 \%$ \\
\hline SunPower (U.S.) & $\mathbf{2 \%}$ \\
\hline Fronius (AT) & $2 \%$ \\
\hline
\end{tabular}

Table 12. Largest Suppliers of Global PV Inverters in 2017, Constructed from Moskowitz (2017)

\begin{tabular}{|r|c|}
\hline Company (HQ, U.S. in Bold) & $\begin{array}{c}\% \text { of } 2017 \\
1^{\text {st } ~} 2^{\text {nd }} \\
\text { quarter } \\
\text { shipments }\end{array}$ \\
\hline Huawei (CN) & $23 \%$ \\
\hline SMA (DE) & $7 \%$ \\
\hline Sineng (CN) & $7 \%$ \\
\hline ABB (CH) & $5 \%$ \\
\hline TBEA SunOasis (CN) & $4 \%$ \\
\hline Power Electronics (ES) & $4 \%$ \\
\hline TMEIC (JP) & $3 \%$ \\
\hline KACO New Energy (DE) & $2 \%$ \\
\hline Fimer (IT) & $2 \%$ \\
\hline Ginlong-Solis (CN) & $2 \%$ \\
\hline Schneider Electric (FR) & $2 \%$ \\
\hline KStar (TW) & $2 \%$ \\
\hline General Electric (U.S.) & $2 \%$ \\
\hline
\end{tabular}

\subsection{Flat Glass}

In c-Si PV modules, typically one sheet of flat glass is used as a front cover, while thin-film modules (such as CIGS and CdTe modules) use two sheets of glass, one as a substrate and one as a front cover. Currently, with the exception of CdTe, most domestically produced PV modules use imported glass. However, as the industry grows, manufacturing PV glass in the United States for domestic consumption might make sense for two reasons: 1) as module costs decline, shipping costs will represent a larger fraction of the module cost, and shipping glass is expensive due to its weight and fragility; and 2) flat glass production is a high-energy 24 hours per day, 7 days per week manufacturing process, and the United States has relatively low fuel prices compared to most other countries (International Energy Agency 2018).

Flat glass can be produced either as rolled glass or on "float lines"- production infrastructure dedicated exclusively to flat glass production (NSG Group 2018, Eurotherm 2018). Solar-grade flat glass differs from typical flat glass in that it requires low iron content for optimal transmissivity. Solar-grade glass can be produced by either float or rolled methods, but each method corresponds to different optical properties, costs, and throughput. The primary focus of this section is on float glass, because it is produced at a larger scale than rolled glass. However, some discussion of rolled glass is also provided. Although it is not clear what percentage of float lines currently produce solar-grade glass, float lines can be modified to produce glass with different properties, so all existing float lines are included in this analysis. 
Global production of flat glass was about 68 million MT in 2017 (Wood 2016), with a market value of roughly $\$ 60$ billion (Persistence Market Research 2017). Figure 24 shows the eight countries with the largest number of float lines in 2017, based on data from Devlin and Dick (2017). The United States has the second largest number of float lines globally but is surpassed by China, which has more than seven times as many.

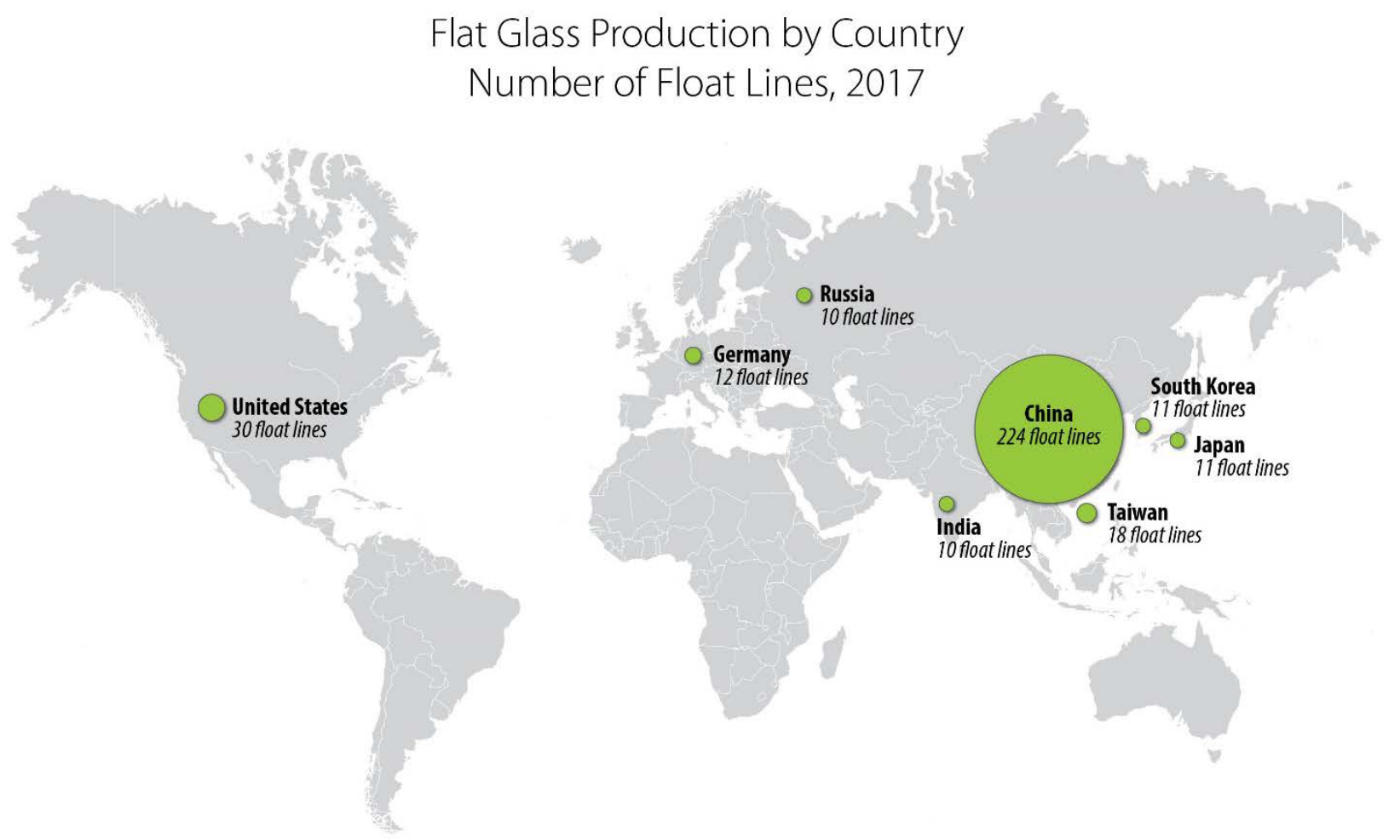

Figure 24. Global leaders in flat glass production in 2017, constructed from data in Devlin and Dick (2017)

The United States produced \$3.5 billion of flat glass in 2017 (assumed to include all methods of manufacturing flat glass, including float, rolled, cast, and blown glass) (IndexBox 2018). Domestic float lines belong to a small number of manufacturers and are primarily located in the eastern half of the United States, as shown in Figure 25 (The National Glass Association and Glass Magazine 2018). Overall, flat glass manufacturing in North America has seen a 23\% reduction in float line capacity since 2005 , but both capacity and production are expected to increase in 2018 due to growth in demand from across building construction sectors (Devlin and Dick 2017).

In Figure 26, the economic value of 2017 flat glass imports and exports is reported by summing the values for HTS codes 7003, 7004, 7005, 7006, 7007, 7008, and 7009 from the U.S.

International Trade Commission (2017), and consumption value is estimated from the difference between these numbers. The figure indicates that the United States relies primarily on domestic production of flat glass. Approximately $40 \%$ of imports were sourced from China and $14 \%$ from Mexico; the remainder were sourced from a long list of countries representing smaller fractions of total imports (USITC 2017). Globally, the main end uses of flat glass by value in 2017 were construction (roughly $70 \%$ ), automotive (14\%), electronics (5\%), and furniture (5\%) (Persistence 
Market Research 2017). Flat glass for solar applications is tempered and typically fabricated with an anti-reflective coating (ARC) before purchase and shipping, so solar glass likely falls under HTS code 7007. In 2017, there were $\$ 954$ million in imports under HTS code 7007, approximately half from China and a tenth from Mexico. Exports under 7007 were worth $\$ 379$ million. For reference, U.S. customs classification rulings often refer to solar glass with an ARC simply as "coverglass."

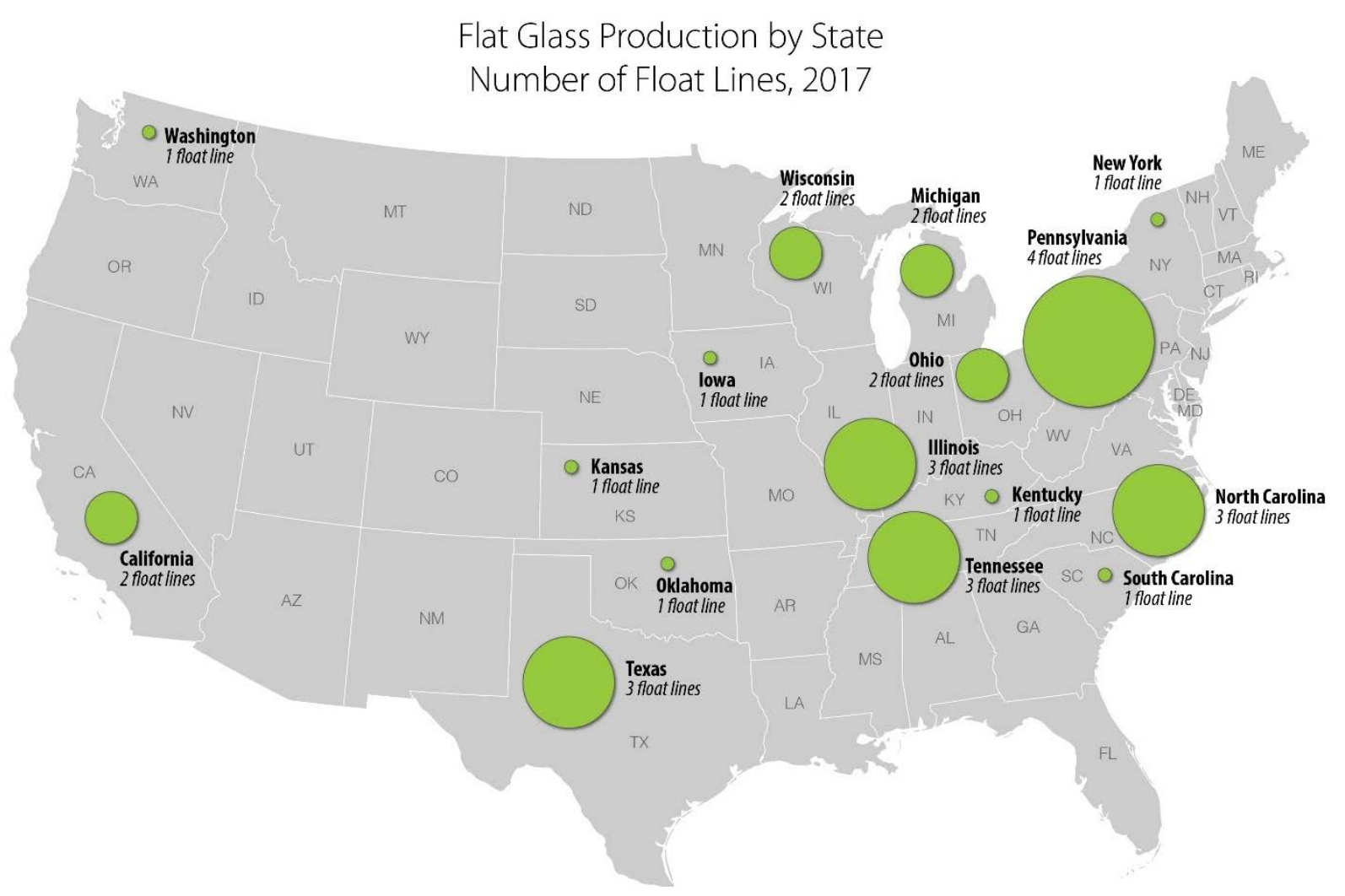

Figure 25. U.S. flat glass production in 2017, constructed from data in The National Glass Association and Glass Magazine (2018)

Interviews with U.S. module manufacturers indicate that all glass for c-Si modules is imported, while most glass for thin-film modules is manufactured in the United States. For simplicity, we assume that U.S. solar-grade glass production in 2017 was equivalent to the amount needed for 2017 U.S. thin-film PV module production. We use glass-intensity assumptions for thin-film modules ( $\$ 46 / \mathrm{kW}$ for CIGS and $\$ 40 / \mathrm{kW}$ for CdTe) and scale by their U.S. production numbers in 2017 (116 MW and $175 \mathrm{MW}$, respectively). This approach yields an estimated \$12 million in value, which represents less than $0.5 \%$ of domestic flat glass consumption. However, if all 10.5 GW of PV installed in the United States in 2017 had been manufactured using domestic flat glass, and assuming the $\$ 22 / \mathrm{kW}$ glass cost for c-Si modules from Woodhouse et al. (2019), the estimated value would have been $\$ 235$ million, or $6 \%$ of domestic glass consumption.

We estimate that the total glass in U.S. PV systems installed in 2017 by weight was about 9 million MT based on data from GrandViewResearch (2018). As with value, this corresponds to about $6 \%$ of domestic flat glass consumption by mass (Table 13). Here we assume $49 \mathrm{~kg}$ of glass per $\mathrm{kW}$ of c-Si modules, based on 3.2-mm thick glass as reported in Woodhouse et al. (2019). If 
we assume all thin-film modules produced in the United States were installed in the United States, then it is appropriate to scale the $49 \mathrm{~kg} / \mathrm{kW}$ intensity by an assumed 10.2 GW of non-thinfilm PV U.S. installations in 2017. The remaining $0.3 \mathrm{GW}$ of thin film modules can be scaled by a weighted average of $92 \mathrm{~kg} / \mathrm{kW}$ using 2018 CdTe and CIGS production data from (GTM Research and SEIA 2018) and mass intensities as defined in the beginning of section 3 .

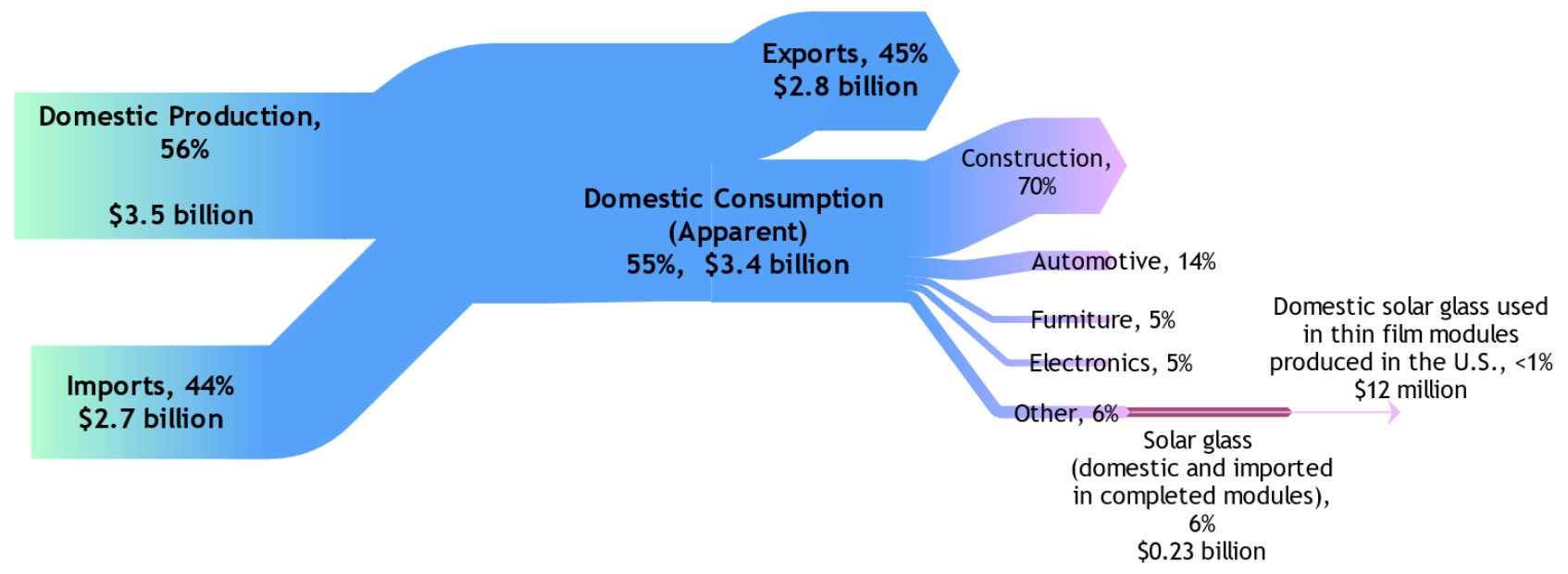

Figure 26. U.S. flat glass consumption in 2017 by input and end use

The data for global PV consumption of flat glass in 2017 was similarly calculated, using the 99 GW of global PV installations in 2017 as reported in Attia, Parikh, and Heggarty (2017) and assuming 4\% of installations can be attributed to thin films as reported in SPV Market Research (2018). Flat glass for global PV installations in 2017 represented 7\% of global consumption of flat glass by weight in 2017. The estimated value of the global solar glass market was $\$ 3.2$ billion in 2016 (GrandViewResearch 2017), which is approximately 5\% of the 2017 global glass market by value; this estimate roughly agrees with the mass-based percentage.

Table 13. Global and Domestic Flat Glass Consumption in 2017 Compared to Solar-Grade Flat Glass Consumption

\begin{tabular}{|r|c|c|}
\hline & \multicolumn{1}{|c}{ Total } & PV Only \\
\hline Global & $68,000,000 \mathrm{MT}$ & $\begin{array}{c}5,000,000 \mathrm{MT} \\
(7 \% \text { of global })\end{array}$ \\
\hline Domestic & $\begin{array}{c}9,000,000 \mathrm{MT} \\
(13 \% \text { of global) }\end{array}$ & $\begin{array}{c}530,000 \mathrm{MT} \\
(6 \% \text { of domestic })\end{array}$ \\
\hline
\end{tabular}

Although the 2017 U.S. flat glass supply was significantly constrained due to multiple accidents that shut down three different float lines (Devlin and Dick 2017), trade data indicate that exports were slightly higher than imports. However, our discussions with U.S. PV module manufacturers indicate that c-Si modules rely on imported flat glass, while thin-film modules use domestically produced solar-grade glass. However, if we assume that all U.S. module production in 2017 used domestic glass - given that one float line produces 140,000 MT of flat glass per year (Pilkington 2018) and PV uses 50,000 MT/GW based on silicon PERC modules as defined in Woodhouse et al. (2019) - then the 2017 level of U.S. module production required the output of less than a single float line. As the U.S. PV industry continues to grow, PV could serve as a catalyst for 
growth in domestic glass production. There are also a number of potential emerging trends in the PV industry that could significantly increase the demand for solar glass per module. For example, a shift to bifacial PV production could use a glass-glass module design, which would double the glass intensity per c-Si module. Expanding production of CdTe PV, which already uses a glass-glass module design, could similarly boost demand for solar glass per module.

Given the recent supply shortage of flat glass and the forthcoming capacity expansion to meet existing demand (Devlin and Dick 2017), further growth in domestic PV manufacturing would likely require additional flat glass production capacity. Because construction of new float lines requires significant time and capital, this could exacerbate the current supply-demand imbalance in the U.S. flat glass market. Rolled plate glass production could potentially provide some solargrade supply in the interim before higher-capacity float lines come online. Ultimately, the domestic production of flat glass for PV could become dominant over imports if PV module prices continue to drop, due to the high costs for shipping glass.

\subsection{Ethylene Vinyl Acetate (EVA)}

Ethylene vinyl acetate is a polymer-based material used as a PV encapsulant. The EVA polymer is used to produce a clear film that encases the solar cells between the cover glass and composite backsheet. Because it is located between the cells and glass, the optical transmission requirements are very high. EVA is used by the PV industry owing to its durability, performance at high temperature, and bonding strength. EVA is synthesized by polymerizing ethylene and vinyl acetate monomers (VAM). Different vinyl acetate densities are available: low-density EVA (LEVA) is typically defined as VAM density below $17 \%$ by weight, medium-density EVA (MEVA) is $17 \%$ to $25 \%$, and high-density EVA (HEVA) is greater than $25 \%$. Once the VAM density passes $40 \%$, the polymer is typically referred to as vinyl acetate ethylene (VAE). PV applications typically require HEVA with $28 \%$ to $33 \%$ VAM density (Sriram et al. 2018). For the purposes of this report, we describe manufacturing of EVA including LEVA, MEVA, and HEVA.

In 2017, global production of EVA polymers was approximately 2.8 million MT (TheMarketReports 2018). Five countries were responsible for nearly $70 \%$ of global production in 2017, as depicted in Figure 27. EVA production was concentrated primarily in China (18\% of production) and nearby countries including South Korea (15\%), Taiwan (13\%), and Japan (6\%), although the United States was the world's second-largest producer (16\%) (Sriram et al. 2018, TheMarketReports 2018).

EVA polymer production in the United States was about 467,000 MT in 2017 (TheMarketReports 2018). Although detailed data on EVA production by state are not available, data on domestic producers of low-density polyethylene (LDPE) in 2016 are available; EVA is a type of LDPE (Smith, Sriram, and Waters 2017). Figure 28 shows the states with the largest LDPE manufacturing capacities in 2016. The total EVA polymer production capacity was approximately 600,000 MT, or $20 \%$ of domestic LDPE capacity (Smith, Sriram, and Waters 2017). Most LDPE production occurs near the Gulf of Mexico, because it benefits from being near fossil fuel production sites that provide LDPE feedstocks. 


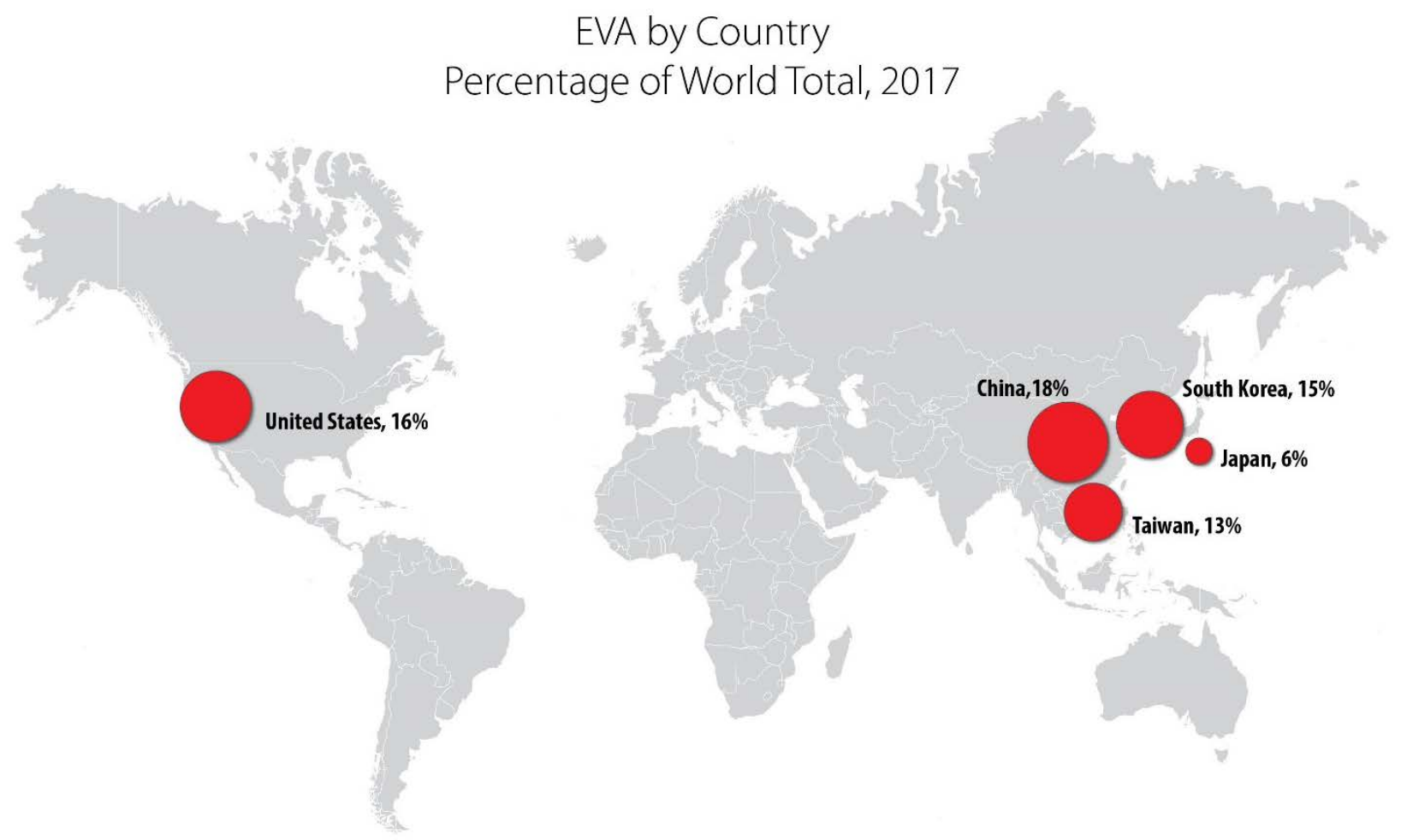

Figure 27. Largest EVA-producing countries in 2017, based on TheMarketReports (2018)

The U.S. customs classification ruling for PV encapsulant sheets (where bulk EVA polymer is extruded into a film) is HTS code 3920.10 (U.S. Customs and Border Protection 2010). This HTS code includes all films composed of ethylene polymers, which represent a wide range of polymer materials. Therefore, the HTS code for the EVA polymer is the main focus of analysis in this section. However, according to the USITC, 2017 U.S. imports of 3920.10 were approximately 430,000 MT, while exports were 328,000 MT.

We use import and export data for HTS code 3901.30 (labeled ethylene vinyl acetate copolymers) to calculate net domestic EVA polymer consumption in 2017, as shown in Figure 29 (USITC 2017). Imports represented 17\% of all EVA polymer in the United States market, with more than 70\% sourced from Canada. In 2017, the United States was a net exporter of EVA polymer; it exported $36 \%$ of all its EVA. We assume that the remainder was consumed domestically. The United States is also an exporter of VAM, the monomer used to synthesize EVA polymers (Sriram et al. 2018). The United States has an export advantage for these materials owing to the availability of ethane-abundant shale natural gas as an ethylene feedstock (Smith, Sriram, and Waters 2017). Lower-density EVA polymers are primarily used to produce films (often for packaging applications), while higher-density EVA is primarily used for hot-melt adhesives (including PV encapsulants) (Sriram et al. 2018).

In calculating domestic consumption of EVA polymers for PV, we assume $5 \mathrm{~kg}$ of EVA film was required per kW of c-Si modules based on Michael and Selvarasan (2017), and a weighted average of $2.7 \mathrm{~kg} / \mathrm{kW}$ for CIGS and CdTe modules. Scaling these factors by $0.68 \mathrm{GW}$ of domestic c-Si module production in 2017 and $0.29 \mathrm{GW}$ of thin-film module production results in our estimate of 4,200 MT of EVA polymer for PV, which is approximately $1 \%$ of domestic EVA 
polymer consumption. However, because the United States is a major exporter of EVA polymer, imported modules might contain sheets of encapsulant extruded from U.S.-produced EVA polymer. If all $10.5 \mathrm{GW}$ of domestic PV installations in 2017 used domestically produced EVA polymers (assuming $0.3 \mathrm{GW}$ are attributed to thin-film modules), this would correspond to $14 \%$ of total domestic EVA polymer consumption. Assuming thin-film modules represent $4 \%$ of the 99 GW of global PV installations in 2017 based on SPV Market Research (2018), EVA polymer for PV accounted for 17\% of global EVA polymer consumption in 2017 (Table 14).

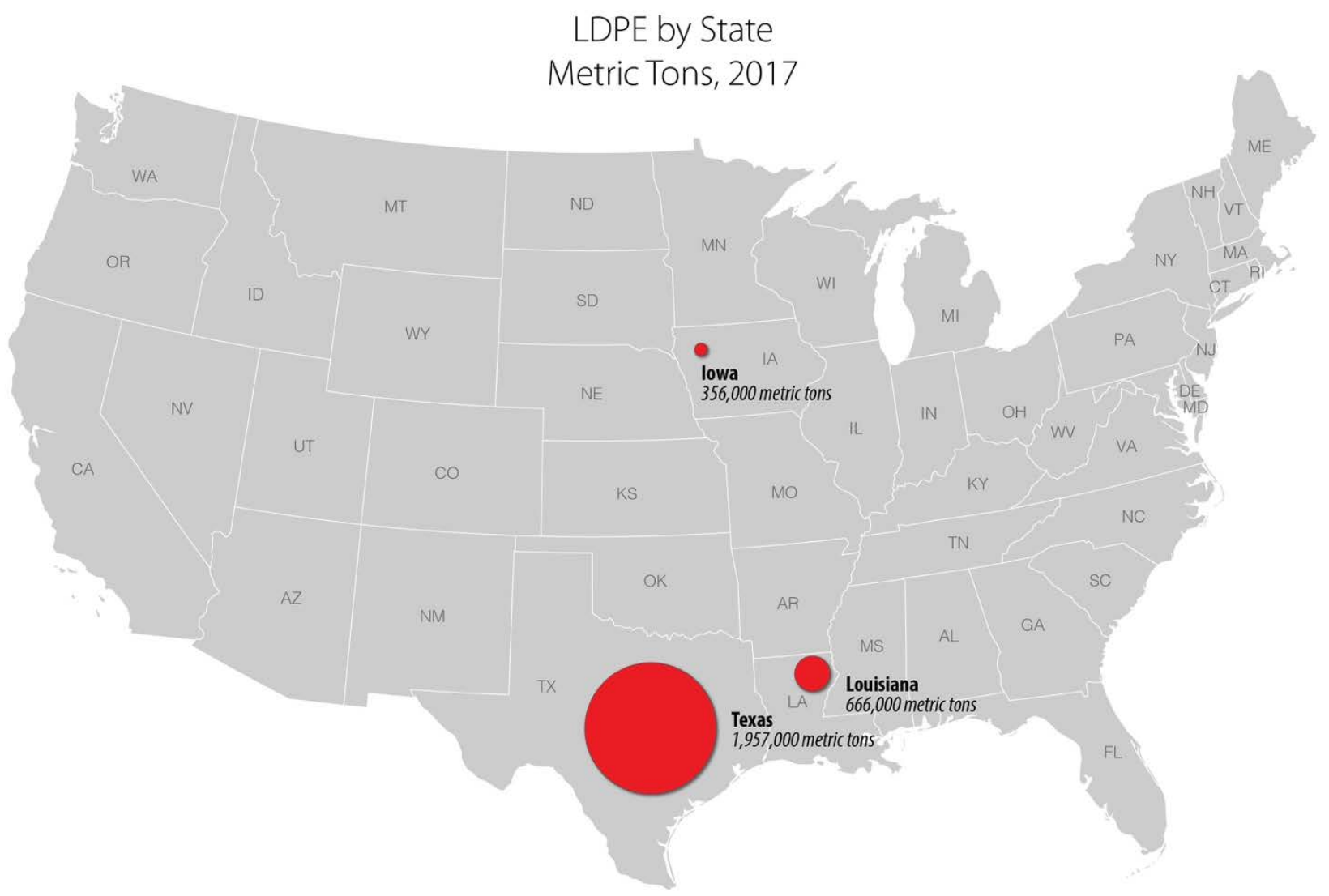

Figure 28. Largest U.S. LDPE-capacity states in 2016, constructed from data in Smith, Sriram, and Waters (2017)

Domestic EVA polymer producers also have multiple routes for competing in international markets. For example, DuPont licenses its PV EVA production technology to companies in China as well as exporting PV EVA masterbatches of the polymer in a solid or concentrated form that can be melted and extruded, and Solutia has opened a PV EVA manufacturing center in China (Smith, Sriram, and Waters 2017). 


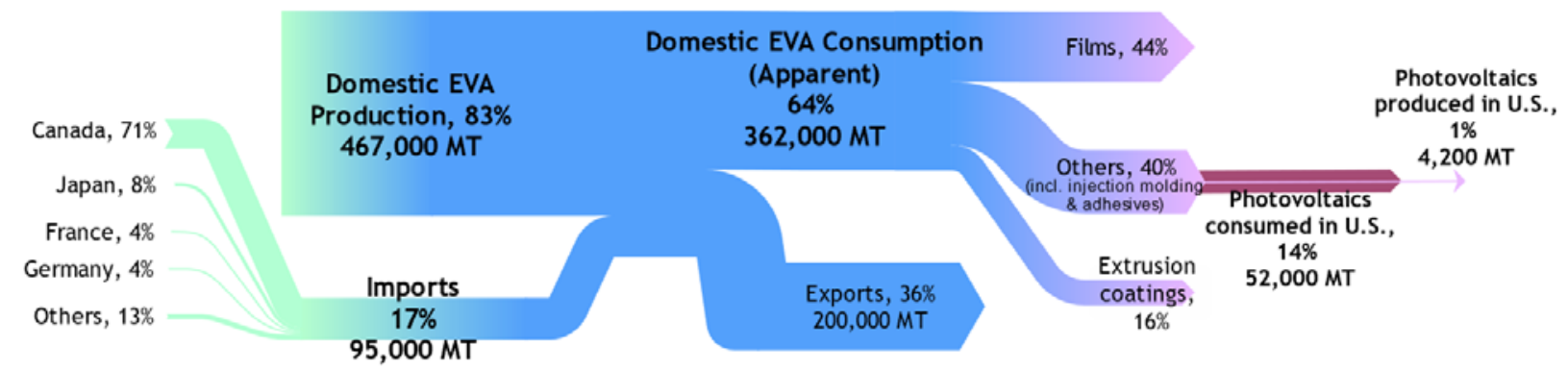

Figure 29. U.S. EVA consumption in 2017 by input and end use, constructed from data in Sriram et al. (2018) and the U.S. International Trade Commission (2017)

Table 14. Global and Domestic EVA Consumption in 2017 Compared to PV EVA Consumption

\begin{tabular}{|r|c|c|}
\hline Global & Total & PV Only \\
& $2,800,000 \mathrm{MT}$ & $\begin{array}{c}485,000 \mathrm{MT} \\
(17 \% \text { of global })\end{array}$ \\
\hline Domestic & $\begin{array}{c}360,000 \mathrm{MT} \\
(13 \% \text { of } \text { global })\end{array}$ & $\begin{array}{c}52,000 \mathrm{MT} \\
(14 \% \text { of domestic })\end{array}$ \\
\hline
\end{tabular}

Going forward, there may be opportunities to expand U.S. EVA polymer production for domestic PV demand as well as for exports. Given that some LDPE reactors can be easily modified to accommodate demand for different polymers, scaling up production of EVA should not be a significant challenge to the industry (Smith, Sriram, and Waters 2017). In addition to having significant LDPE capacity, the United States also has low-cost feedstocks due to domestic shale gas production (Smith, Sriram, and Waters 2017). This combination could give the United States a competitive advantage in scaling up EVA polymer production to meet the needs of a growing domestic and global PV market.

\subsection{Tedlar}

Tedlar is a polyvinyl fluoride (PVF) film patented by DuPont and used in the backsheet of $25 \%$ $30 \%$ of PV modules on the market today (Chunduri and Schmela 2018). Backsheets are intended to electrically insulate the module and protect it from moisture, wind, and ultraviolet light damage. Tedlar dominated the PV backsheet market until around 2005, when it became apparent that demand would soon begin to outpace supply and research into alternative backsheet materials began in earnest (Ebnesajjad 2012). A typical backsheet consists of two sheets of Tedlar, which encase a layer of polyethylene terephthalate or polyester. Tedlar is manufactured using a gel extrusion process of PVF resins (Greiner 2016), where vinyl fluoride is synthesized from acetylene and hydrogen fluoride (Suresh 2017).

Due to intellectual property rights, Tedlar is only manufactured by DuPont at the locations shown in Figure 30 (Ebnesajjad 2012). The annual Tedlar film extrusion capacity in the United States is $6,500 \mathrm{MT}$, while the capacity for PVF resin production is $6,800 \mathrm{MT}$. Only a small amount of PVF resin is produced elsewhere globally (Ebnesajjad 2012). If we assume 1,000 MT of additional PVF polymer resin capacity outside of the United States, and that all production facilities operate at $90 \%$ capacity, global PVF resin production is approximately 7,000 MT annually, which is consistent with reports of annual global PVF consumption (Greiner 2016). A 
high capacity utilization rate of $90 \%$ is assumed given the high demand for Tedlar, which resulted in supply shortages around 2005 (Ebnesajjad 2012). The global market for PVF in 2017 was valued at approximately $\$ 1$ billion (Future Market Insights 2017). The largest end-use of PVF resin is for Tedlar production for PV applications. Other uses of Tedlar and PVF resins include release films for circuit board printing, laminate in aircraft and motor vehicle interiors, wall coverings for hospitals and hotels, coverings for weather-resistant furniture, canopies, and signs, and bags for vehicle emissions testing (Greiner 2016).

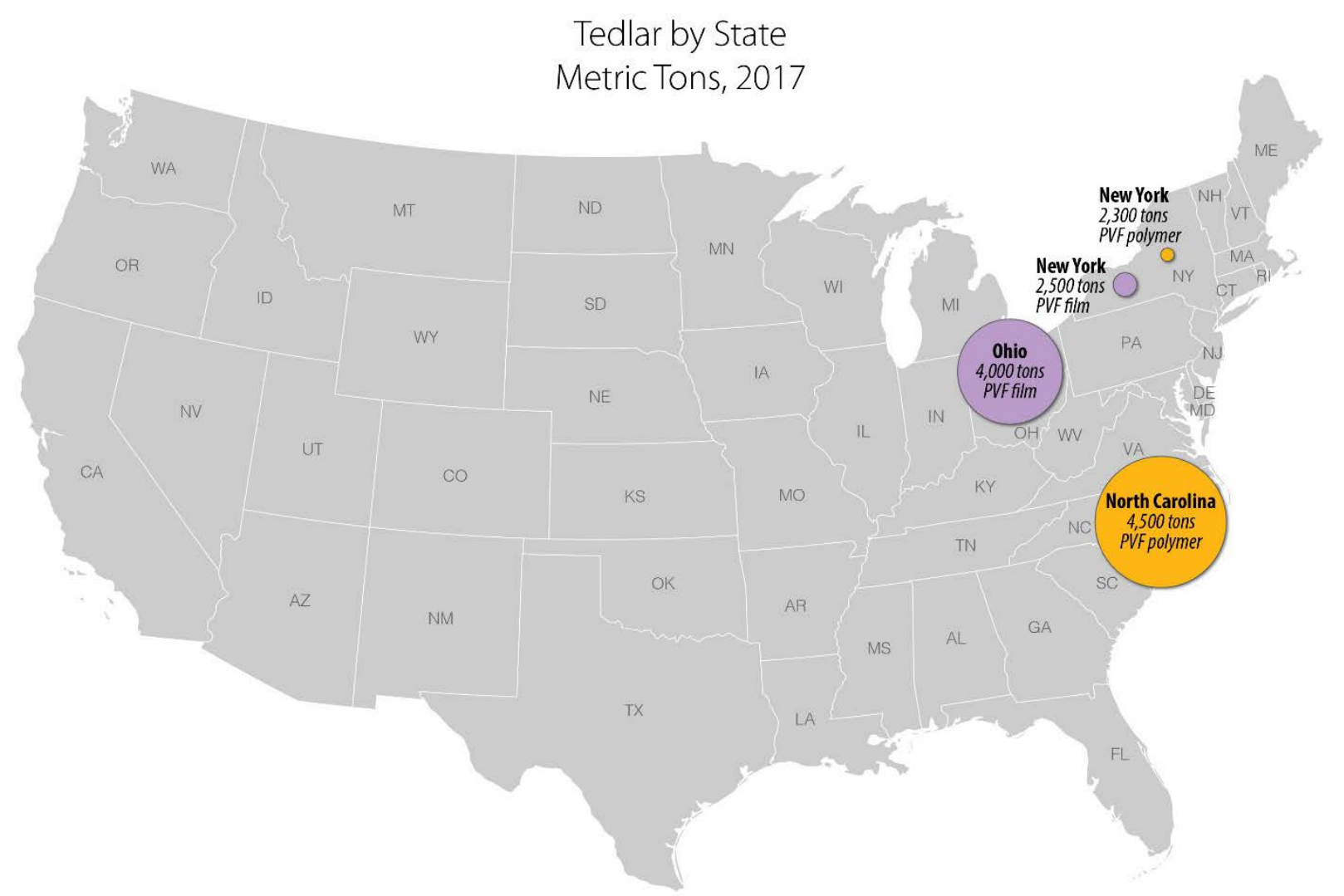

Figure 30. PVF resin manufacturing locations and Tedlar film extrusion locations (also referred to as PVF film extrusion locations), annual capacity reported in MT, based on Ebnesajjad (2012)

Consumption of PVF resin in the United States was roughly 5,000 MT in 2017, while the United States exported approximately 1,000 MT of PVF (in either resin or Tedlar film format) each to Europe and China (Greiner 2016), based on extrapolation of 2015 data. More recent confirmation of trade data for both PVF resin and film is challenging; there does not appear to be an HTS code for the resin, while the code associated with PVF film is 3920.99 .2000 (U.S. Customs and Border Protection 1997), which serves as a miscellaneous category for singlematerial plastic sheets that are not accounted for by other more specific HTS codes. However, it has been reported that PV applications were responsible for $58 \%$ of U.S. PVF resin consumption in 2015 (Greiner 2016). The trade classification for PV backsheets likely differs from that of PVF film, because backsheets contain stacks of multiple different plastic materials that fall under HTS code 3921 (stacks of films, or laminates). Furthermore, because backsheets are often constructed with a built-in adhesive, they may fall under HTS code 3919, which refers to selfadhesive films. 
The amount of PVF needed for global PV installations in 2017 can be estimated by assuming that $20 \%$ of panels used two sheets of Tedlar 2111 in a Tedlar/polyester/Tedlar (TPT) configuration, and an additional $5 \%$ of installations only used one sheet in a Tedlar/polyethylene terephthalate/polyamid (TPE) configuration, based on a roughly $4: 1$ ratio reported by the ITRPV Working Group (2018). This corresponds to $0.3 \mathrm{~kg}$ per $\mathrm{kW}$ if two sheets are used, or $0.15 \mathrm{~kg}$ per $\mathrm{kW}$ if only one sheet is used. This implies that a 2,000-MT Tedlar film extrusion plant could supply approximately 6-13 GW of PV.

The $0.68 \mathrm{GW}$ of U.S.-manufactured c-Si modules in 2017 correspond to roughly $50 \mathrm{MT}$ of Tedlar. However, because the United States is the major producer of Tedlar, it is likely that Tedlar-containing backsheets in imported modules were produced in the United States. This would correspond to 720 MT of PVF resin for all 2017 U.S. PV installations, and 6,700 MT for global solar installations (Table 15). Thus, the global PV industry represents the majority of the global demand for PVF.

Table 15. Global and Domestic PVF Resin Consumption in 2017 Compared to PV PVF Resin Consumption

\begin{tabular}{|r|c|c|}
\hline & Total & PV Only \\
\hline Global & $7,000 \mathrm{MT}$ & $\begin{array}{c}6,700 \mathrm{MT} \\
(96 \% \text { of global })\end{array}$ \\
\hline Domestic & $\begin{array}{c}5,000 \mathrm{MT} \\
\text { (70\% of global) }\end{array}$ & $\begin{array}{c}720 \mathrm{MT} \\
\text { (14\% of domestic) }\end{array}$ \\
\hline
\end{tabular}

The United States is currently the dominant supplier in the PVF industry, and PV is the dominant application generating PVF demand in the form of Tedlar films. Although a growing percentage of PV is anticipated to use alternative backsheet materials in the coming years (ITRPV Working Group 2018), there is often uncertainty regarding the longevity of some alternative backsheet materials to which Tedlar has lost market share, given the difficulty of testing for reliability over a lifetime of exposure (Kurtz et al. 2013, Pickerel 2016). Therefore, it is not unreasonable to expect that continued growth in PV installations would require further growth of current PVF resin and film capacity. However, a shift to bifacial PV production could offset the demand for backsheets overall if a glass-glass module construction is used. Conversely, bifacial PV could also represent a new market segment if transparent backsheets are used in place of rear cover glass (Hutchins 2018). 


\section{Discussion of Growth Scenarios}

The U.S. market for PV installations has grown rapidly over the last 10 years and has potential to continue growing. The percentage of U.S. electricity generation from solar in 2017 was still only $1.3 \%$ of total generation (U.S. Energy Information Administration 2018), but solar (mostly PV) accounted for $30 \%$ of total new U.S. generation capacity between 2013 and 2018 (Solar Energy Industries Association 2018). If the PV market continues to grow, then demand for PV components and materials would increase.

To explore the potential impacts of increased PV demand on the supply chain, we analyze two U.S. PV growth scenarios: a twofold increase in PV demand (to $20 \mathrm{GW} /$ year) and a tenfold increase (to $100 \mathrm{GW} /$ year). Annual demand of $20 \mathrm{GW}$ could occur as early as 2021 if PV prices continue to drop, while annual demand greater than $80 \mathrm{GW}$ would only occur after 2040 if lowcost storage becomes widely available (Jones-Albertus et al. 2018).

This section exclusively considers the infrastructure availability to meet demand in industries upstream of PV manufacturing assuming all U.S. PV installations are manufactured domestically from domestically sourced materials and components. It does not evaluate economic factors such as cost-competitiveness with other countries, policy incentives, shipping costs, and so forth, which are important factors to evaluate but are outside the scope of this work. We delineate the infrastructure challenges and opportunities that the upstream U.S. manufacturing sectors could encounter if the U.S. PV manufacturing sector grows at a modest or accelerated rate. However, commodity pricing as well as many other factors could affect the ability for U.S. growth in these manufacturing sectors. This analysis could be used in future discussions of the feasibility of creating a domestic PV supply chain that relies on domestic sourcing for upstream materials. It could also be leveraged in future research that considers more dynamic assessments of demand, cost, and policy actions.

Figure 31 shows the potential impact on demand under our two cases for each material and component discussed in Section 2.4: steel, aluminum, inverters, flat glass, EVA, and Tedlar. Shown are a case in which the U.S. share of installations from domestic production stays constant at the 2017 level as well as a case in which U.S. production grows sufficiently to meet domestic demand.

At the 2017 level of demand for U.S. PV, PV does not dominate the domestic manufacturing supply chain for any of these materials or components. In 2017, even if the United States had supplied all PV demand via domestically produced materials or components in these markets, in each case they would have accounted for a relatively small fraction of total production (from a low of $1 \%$ for steel to a high of $19 \%$ for inverters). We conclude that the U.S. supply of these key materials and components is not constrained at the current PV market level. In other words, the United States could shift to meeting an increasing share of domestic PV market needs via U.S.-based production without putting excess pressure on the supply chains for these materials and components. In a number of cases, a shift to domestic production could leverage existing excess manufacturing capacity and access to relatively low-cost energy supplies.

The two domestic markets with the largest potential impact in our two growth cases are inverters and EVA. If the market doubles and demand is met via domestic sources, then demand for 
inverters could reach $38 \%$ of 2017 production, and demand for EVA could reach $22 \%$. If the market increases by a factor of 10, then the current domestic production capacity for inverters and EVA could be eclipsed, potentially requiring triple (for inverters) or more than double (for EVA) the amount of 2017 production levels, assuming all other sources of demand remain constant. However, these industries could likely adapt to this type of demand growth relatively quickly, because LDPE production facilities are often easily converted to produce EVA, and inverters are largely assembled from commodity materials and components.

Markets for flat glass and Tedlar could also be significantly affected if PV installations increase by a factor of 10 and there is a shift to domestic production. Under this scenario, the demand for Tedlar could double, and the demand for flat glass could increase by $60 \%$ above 2017 production levels, assuming other sources of demand remain constant. This type of growth could provide a significant opportunity to expand these industries in the United States; however, it might also present some risks and challenges.

Existing float lines can be modified to produce solar-grade glass, but the conversion is time consuming and potentially costly. If demand increases too rapidly, short-term solar glass demand-supply imbalances could emerge. Ultimately in this type of growth scenario, the industry would likely need to develop dedicated low-iron solar glass float lines. Assuming that one float line produces 140,000 MT of flat glass per year (Pilkington 2018), and PV uses 50,000 $\mathrm{MT} / \mathrm{GW}$, then the 2017 level of U.S. module production required the output of less than a single float line. In the $2 \mathrm{x}$ scenario, assuming all $\mathrm{PV}$ is produced domestically, $\mathrm{PV}$ demand could require the output of up to seven dedicated solar glass float lines, which would be equivalent to $12 \%$ of the 2017 U.S. flat glass industry. This level of growth could be accommodated by the existing glass industry via shifting production at existing facilities, increasing production of rolled solar-grade plate glass, and/or modestly expanding new production. The 10x scenario could require roughly 37 dedicated float lines, i.e., a 60\% increase over the 2017 size of the U.S. flat glass industry (including rolled plate glass). This level of growth would represent a dramatic shift in the U.S. glass industry.

Tedlar capacity expansion historically has been achieved via new U.S. facilities with greater than 2,000 MT in annual production capacity (Ebnesajjad 2012). If this minimum scale of production continues to be required for expanding production, then short-term Tedlar supply constraints could emerge. Assuming that roughly $60 \mathrm{MT}$ of Tedlar are needed per GW (retaining the current $25 \%$ market share), $33 \mathrm{GW}$ of annual domestic PV production would be necessary to fully utilize a new 2,000-MT Tedlar facility (2,000 MT for the PVF polymer and 2,000 MT for film extrusion). In the $2 \mathrm{x}$ scenario, $\mathrm{PV}$ demand could thus require the output of up to roughly one new facility, while in the 10x scenario PV demand could require up to three new 2,000-MT facilities.

Finally, aluminum and steel have no significant supply constraints for meeting the 2x scenarios. In our more aggressive 10x case, supplying aluminum for the U.S. PV market could require an increase in aluminum production of roughly 40\% above 2017 levels. Using the excess aluminum capacity that currently exists in the United States could meet this demand and avoid the need to build new primary aluminum production. Comparatively, steel does not show constraint concerns in the more aggressive 10x case; it would only require an increase in production of about $8 \%$. Again, using current excess capacity could serve to meet this level of expansion relatively easily. 


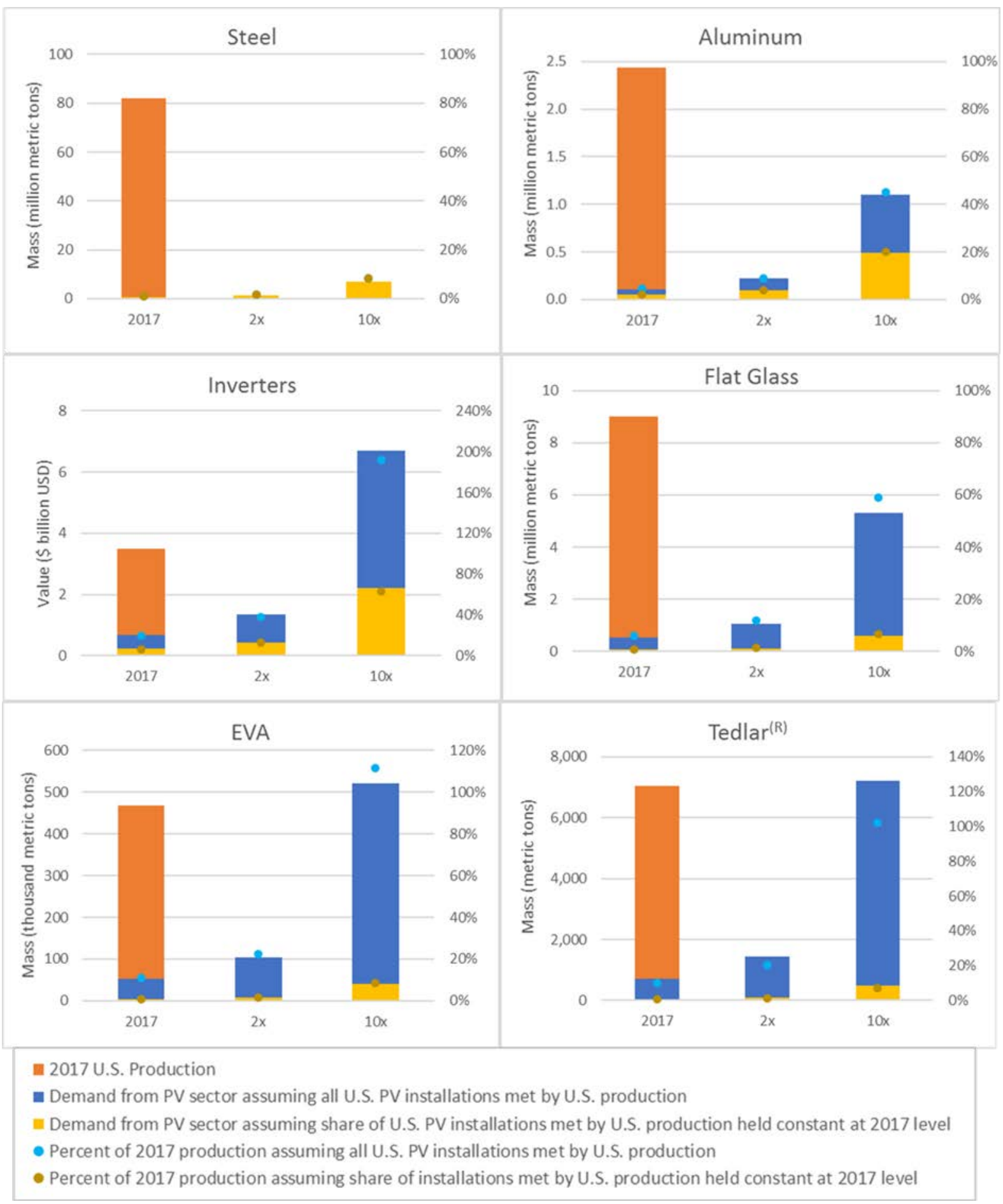

Figure 31. U.S. material and component demand for PV at current, $2 x$, and $10 x$ installations 


\section{Research Gaps}

This research acknowledges the following gaps in research and analysis and encourages additional effort to be made in the following areas:

- Expanding analysis to additional PV components and materials prioritized by their potential for creating a U.S. competitive advantage and a differentiated U.S. product. This could include products that are significantly differentiated from the broader global market such as highly automated PV manufacturing equipment or advanced PV architectures like highefficiency silicon cells or bifacial modules. This could also include materials of which the United States is already a net exporter, or components that would require domestic production for cybersecurity reasons such as power electronics.

- Assessing the upstream jobs that would be produced and the overall contribution to gross domestic product by sector, including analysis specific to the regions where sectors would be located.

- Quantifying the costs of shipping the individual components and the benefits of co-locating these sectors, and then optimizing which components should be produced locally versus imported based on this analysis.

- Creating a dynamic model of demand for domestic production of these components based on scale, cost, and policy scenarios similar to that used in Sandor et al. (2018), and then using this model to identify when supply constraints would occur.

- Identifying which PV components rely on rare earths or other critical materials that could encounter supply constraints if the industry grows, based on issues such as crust abundance or market control by a limited number of exporters.

- Analyzing the comparative advantages or disadvantages of developing a U.S. supply chain for emerging PV technologies, such as perovskites, which would have significantly different material and infrastructure needs. 


\section{Conclusions}

Although the total manufacturing volume of solar-grade polysilicon as well as PV cells and modules has declined in the United States over recent years, U.S. demand for PV systems continues to increase. Our analysis enables us to make several inferences about the U.S. polysilicon-to-module supply chain. U.S. polysilicon production in 2017 was roughly equivalent to the amount needed for 2017 U.S. PV demand, even while operating below $50 \%$ capacity. However, there are currently no U.S. producers of silicon ingots or wafers for solar applications, so we assume that U.S. polysilicon is either used for electronic applications or exported. As such, we assume that the 260 MW of U.S. c-Si PV cell production in 2017 relied entirely on imported wafers. Imports supplied about $60 \%$ of the 2017 U.S. market for c-Si cells and $92 \%$ of the market for PV modules including thin-film PV. Additionally, roughly 4\% of c-Si cells and 18\% of all PV modules were stockpiled in 2017 due to anticipated policy uncertainty.

However, during 2017 through mid-2019, U.S. manufacturers announced plans to add a total of 1.6 GW of c-Si cell production capacity, $6.2 \mathrm{GW}$ of c-Si module capacity, and $1.2 \mathrm{GW}$ of thinfilm module capacity. If these announced expansions are built, they would represent a tenfold increase in U.S. c-Si cell capacity and a threefold increase in U.S. module (c-Si plus thin-film) capacity, compared with the production capacities that have carried over from the first quarter of 2017-which could impact the U.S. supply chains for input materials. Furthermore, if CapEx and PV prices continue to decrease while automation continues to increase, local manufacturing may begin to be more economical compared to shipping costs. In this context, we draw conclusions about U.S. supply chains for the six most costly PV materials and components outside the polysilicon supply chain: steel, aluminum, inverters, flat glass, EVA, and Tedlar.

Steel. In 2017, the total U.S. steel market relied primarily (70\%) on domestically produced steel. In 2016, the United States produced a quantity of steel PV racking roughly equal to the amount used by all ground-mounted PV installed that year, suggesting that the United States could have met its own demand for steel PV racking production, although it is uncertain what fraction of the steel used to construct the racking was from domestic sources. Because the amount of steel used in U.S. PV installations in 2017 represented less than 1\% of total U.S. steel consumption, and U.S. steel production has been operating below $80 \%$ capacity utilization, growth in PV installations could have modest benefits for local steel production without encountering supply constraints.

Aluminum. In 2017, domestic aluminum production supplied $28 \%$ of the total U.S. aluminum market, even though U.S. primary aluminum manufacturing capacity was at less than $50 \%$ utilization. In 2016, the United States produced a quantity of aluminum PV racking roughly equal to the amount needed for its rooftop PV installations, suggesting that the United States can meet its own demand for aluminum PV racking, even though the domestically produced racking in 2016 was likely constructed by extruding imported aluminum. Because the United States relies significantly on imported PV modules, these typically arrive assembled with a foreignsourced aluminum frame. The total amount of aluminum contained in U.S. PV installations in 2017 (including frames) represented less than $2 \%$ of total U.S. aluminum consumption. Thus, if domestic aluminum becomes cost-competitive with foreign aluminum, growth in PV installations or PV module assembly could help occupy idle primary aluminum production capacity without encountering supply constraints. 
Inverters. In 2017, the total U.S. market for all inverter applications (including PV) relied primarily (71\%) on domestic inverter production. However, 2017 U.S. production of PV inverters was roughly equal to $40 \%$ of PV inverters installed domestically that year, where PV inverters account for approximately $15 \%$ of the total U.S. inverter market. Although the domestic share of PV inverters has declined significantly over the past several years, concerns have begun to emerge regarding grid cybersecurity when relying on foreign-produced power electronics. If this concern persists, it could stimulate a return to higher domestic PV inverter production by trusted domestic suppliers.

Flat glass. In 2017, the total U.S. flat glass market relied primarily (56\%) on domestic production. Because glass is fragile and dense and therefore expensive to ship, growth in U.S. PV module production could represent an opportunity for growth in the U.S. flat glass industry. In 2017, U.S. PV module production represented less than 1\% of total U.S. flat glass consumption. However, given the current demand in the flat glass market as well as the time and capital required to construct new lines, accelerated growth in U.S. PV module manufacturing could result in flat glass supply-demand imbalances, particularly if glass-glass thin-film or bifacial modules gain in market share.

EVA. We assume EVA is the most common PV encapsulant material. The United States was a net exporter of EVA in 2017, and it has a global advantage in production of EVA and other LDPE owing to the abundance of inexpensive shale-gas feedstocks. PV module production in the United States in 2017 represented less than 1\% of the total amount of U.S. EVA consumption. The total amount of EVA contained in 2017 U.S. PV installations represented 14\% of total 2017 U.S. EVA consumption in all sectors, suggesting that growth of U.S. PV module manufacturing could become a major driver of domestic EVA production. Because most LDPE reactors can be easily modified to produce EVA, the United States could expand production to meet growth in domestic and global PV demand for EVA.

Tedlar. We analyze Tedlar as a primary material in PV backsheets, because the United States is the primary global supplier of Tedlar (a PVF film extruded from PVF resin). In 2017, 25\%-30\% of PV backsheets used at least one sheet of Tedlar. We estimate that up to $96 \%$ of PVF resin is consumed by the PV industry and that all the Tedlar contained in U.S. PV installations was produced domestically. Given the uncertain longevity of alternative backsheet materials and the potential of transparent Tedlar replacing back cover glass in bifacial modules (which are expected to gain market share), Tedlar demand may increase further as global PV installations grow, prompting new capacity additions.

We quantify the potential impact of PV demand growth on the markets for each of these components by considering two scenarios - one with domestic PV demand doubling, and another with demand increasing tenfold - under two different assumptions: either all demand is met by domestic production, or the percentage of demand met by domestic production is held constant at 2017 levels. Demand from U.S. PV installations in 2017 would have been less than $20 \%$ of total U.S. production for any given component, even if all 2017 U.S. PV installations had been supplied via domestically sourced components. If all demand is met by domestic production in the $2 \mathrm{x}$ scenario, U.S. PV demand would be a significant driver in the markets for EVA (PV would account for $20 \%$ of total 2017 production) and inverters (40\%). In the 10x scenario when all PV demand is met by domestic production, the markets would be heavily affected for flat 
glass (U.S. PV would account for $60 \%$ of total 2017 production), aluminum (40\%), Tedlar $(100 \%)$, EVA $(110 \%)$, and inverters $(180 \%)$. In the cases explored here, only steel would not be supply constrained. Even under the most aggressive scenario (10x production with all demand met domestically), steel demand increases to only $8 \%$ of 2017 production levels.

Ultimately, the growth of the U.S. PV industry could represent significant potential for growth in upstream industries. The United States is already an exporter of PV components such as EVA and Tedlar. When looking across key PV components and materials, the United States does not rely heavily on imports of flat glass and steel. If U.S. PV module manufacturing increases, it might rely more on domestic sources for a range of components and materials. The United States currently relies mostly on imports of aluminum and PV inverters, but it still has significant domestic production capacity that could be increased with relative ease if PV demand for domestic components increases. Specifically, inverters and EVA have existing manufacturing capacity that would be relatively easy to adapt and scale (less capital and time intensive than other industries). Flat glass and Tedlar, in contrast, would require larger investments and more time to expand production, but increasing PV demand could serve as a catalyst for industry growth. In addition, because the United States has significantly underutilized steel and aluminum production capacity, it could be feasible to move towards extruding racking and module frames from domestic sources if they can be cost-competitive with foreign sources. 


\section{References}

AIM Market Research. 2010. "Steel Plants of North America." accessed June 5, 2019. https://www.steel.org/Making\%20Steel/ /media/Files/AISI/Making\%20Steel/2010_Steel Plant_NorthAmerica_HypocycloidVersion6.ashx.

Anderton, James. 2015. "New Micro Steel Mill is Competitive Despite Low Steel Prices." accessed June 5, 2019. https://www.engineering.com/AdvancedManufacturing/ArticleID/10516/New-MicroSteel-Mill-is-Competitive-Despite-Low-Steel-Prices.aspx.

Andorka, Frank. 2017. Panasonic to close Oregon ingot factory and eliminate 92 jobs. https://pvmagazine-usa.com/2017/09/08/panasonic-to-close-oregon-ingot-factory-and-eliminate92-jobs/.

Attia, Benjamin, Manan Parikh, and Tom Heggarty. 2017. Global Solar Demand Monitor - 2017 Q4. https://www.greentechmedia.com/research/report/global-solar-demand-monitor-q42017\#gs.EgTuock.

Barbose, G. L., N. R. Darghouth, D Millstein, K. H. LaCommare, N DiSanti, and R Widiss. 2017. Tracking the Sun 10: The Installed Price of Residential and Non-Residential Photovoltaic Systems in the United States. https://emp.lbl.gov/publications/tracking-sunx-installed-price: Lawrence Berkeley National Laboratory.

Beetz, Becky. 2018. "Silfab unveils US manufacturing site with $\$ 40$ million investment in Itek Energy." accessed June 5, 2019. https://www.pv-magazine.com/2018/08/30/silfabunveils-us-manufacturing-site-with-40-million-investment-in-itek-energy/.

BNEF. 2018. Bloomberg New Energy Finance. New York.

Castellanos, Sergio, José E. Santibañez-Aguilar, Benjamin B. Shapiro, Douglas M. Powell, Ian M. Peters, Tonio Buonassisi, Daniel M. Kammen, and Antonio Flores-Tlacuahuac. 2018. "Sustainable silicon photovoltaics manufacturing in a global market: A techno-economic, tariff and transportation framework." Applied Energy 212:704-719. doi: https://doi.org/10.1016/j.apenergy.2017.12.047.

Chunduri, Shravan K., and Michael Schmela. 2018. Market Survey on Solar Backsheets 2018. http://taiyangnews.info/reports/market-survey-on-solar-backsheets-2018/: Taiyang News.

Cowen Inc. 2018. Sustainable Energy \& Industrial Technology. New York: https://www.cowen.com/sectors/sustainableenergyindustrialtechnology/.

Credit Suisse Group AG. 2018. Research Institute. Zurich, Switzerland: https://www.creditsuisse.com/corporate/en/research.html.

Danko, Pete. 2018. SunPower updates timing on SolarWorld acquisition wrapping up. https://www.bizjournals.com/portland/news/2018/07/30/sunpower-solarworldacquisition-will-wrap-up.html.

Dehghani, Ehsan, Mohammad Saeed Jabalameli, and Armin Jabbarzadeh. 2018. "Robust design and optimization of solar photovoltaic supply chain in an uncertain environment." Energy 142:139-156. doi: https://doi.org/10.1016/j.energy.2017.10.004.

Deign, Jason. 2018. Silfab and DSM Partner to Boost Solar Module Output by 30\%. https://www.greentechmedia.com/articles/read/solar-firms-join-forces-in-push-forgreater-efficiency.

Deutsche Bank AG. 2018. Deutsche Bank Research. Frankfurt, Germany: https://www.dbresearch.com/.

Devlin, Katy, and Norah Dick. 2017. "Supply \& Demand." accessed June 6, 2019. https://glassmagazine.com/article/commercial/supply-demand-1717387. 
Ebnesajjad, Sina. 2012. Polyvinyl fluoride: Technology and applications of PVF. Oxford, UK: William Andrew.

Eurotherm. 2018. "Flat Glass Manufacturing." accessed December 4, 2018. https://www.eurotherm.com/flat-glass.

Feldman, David J, Robert M Margolis, and Jack Hoskins. 2018. Q4 2017/Q1 2018 Solar Industry Update. https://www.nrel.gov/docs/fy18osti/71493.pdf: National Renewable Energy Lab.(NREL), Golden, CO (United States).

Foehringer Merchant, Emma. 2018. Sunpreme Plans Texas Cell and Module Facility in 2019. https://www.greentechmedia.com/articles/read/sunpreme-confirms-texas-cell-andmodule-facility: GreenTech Media.

$\mathrm{Fu}$, Ran, David J. Feldman, Robert M. Margolis, Michael A. Woodhouse, and Kristen B. Ardani. 2017. US Solar Photovoltaic System Cost Benchmark: Q1 2017. https://www.nrel.gov/docs/fy17osti/68925.pdf: National Renewable Energy Laboratory (NREL), Golden, CO (United States).

Fu, Ran, Ted L James, and Michael Woodhouse. 2015. "Economic measurements of polysilicon for the photovoltaic industry: market competition and manufacturing competitiveness." IEEE Journal of Photovoltaics 5 (2):515-524. doi: https://doi.org/10.1109/JPHOTOV.2014.2388076.

$\mathrm{Fu}$, Ran, Robert M Margolis, and David J Feldman. 2018. US Solar Photovoltaic System Cost Benchmark: Q1 2018. https://www.nrel.gov/docs/fy19osti/72399.pdf: National Renewable Energy Lab (NREL), Golden, CO (United States).

Future Market Insights. 2017. "Fluoropolymers Market: PTFE Product Type Segment to Lead in Terms of Market Share Throughout the Forecast Period: Global Industry Analysis (2012 2016) and Opportunity Assessment (2017 - 2027)." accessed June 6, 2019. https://www.futuremarketinsights.com/reports/fluoropolymers-market-102017.

Gallagher, Dave. 2017. This new Bellingham solar facility will add jobs to town. https://www.bellinghamherald.com/news/local/article177546761.html.

GlobalWafers. 2018. "Overview/Locations - GlobalWafers." https://www.gwsemi.com/overview-locations/.

Goldman Sachs. 2018. Global Markets Institute. New York: https://www.goldmansachs.com/what-we-do/research.html.

Goodrich, A., T. James, and M. Woodhouse. 2011. Solar PV Manufacturing Cost Analysis: U.S. Competitiveness in a Global Industry. https://www.nrel.gov/docs/fy12osti/53938.pdf: NREL Golden, Colorado.

Goodrich, Alan C, Douglas M Powell, Ted L James, Michael Woodhouse, and Tonio Buonassisi. 2013. "Assessing the drivers of regional trends in solar photovoltaic manufacturing." Energy \& Environmental Science 6 (10):2811-2821.

Goodrich, Alan, Peter Hacke, Qi Wang, Bhushan Sopori, Robert Margolis, Ted L James, and Michael Woodhouse. 2013. "A wafer-based monocrystalline silicon photovoltaics road map: Utilizing known technology improvement opportunities for further reductions in manufacturing costs." Solar Energy Materials and Solar Cells 114:110-135. doi: https://doi.org/10.1016/j.solmat.2013.01.030.

GrandViewResearch. 2017. Solar PV Glass Market Size Worth \$33.7 Billion By 2025 |CAGR: 30.9\%. https://www.grandviewresearch.com/press-release/global-solar-pv-glass-market.

GrandViewResearch. 2018. Flat Glass Market Size Worth \$124.14 Billion By 2022 |CAGR 7.1\%. https://www.grandviewresearch.com/press-release/flat-glass-market. 
GreenBrilliance USA. 2018. GreenBrilliance USA announces PV manufacturing in the United States. https://pv-magazine-usa.com/press-releases/greenbrilliance-usa-announces-pvmanufacturing-in-the-united-states/.

Greiner, Elvira. 2016. Other fluoropolymers - Consumption - United States : Fluoropolymers Chemical Economics Handbook. IHS Markit.

Groom, Nichola. 2019. "Exclusive: Tesla's solar factory is exporting most of its cells." accessed May 23, 2019. https://www.reuters.com/article/us-tesla-solar-exclusive/exclusive-teslassolar-factory-is-exporting-most-of-its-cells-document-idUSKCN1SL1H5.

GTM Research, and SEIA. 2011. U.S. Solar Market Insight Report 2010 Year in Review. https://www.seia.org/sites/default/files/us-solar-market-insight-report-q1-2011120627093305-phpapp01.pdf.

GTM Research, and SEIA. 2012. U.S. Solar Market Insight Report 2011 Year-in-Review. https://www.seia.org/research-resources/us-solar-market-insight-report-2011-yearreview.

GTM Research, and SEIA. 2013. U.S. Solar Market Insight Report 2012 Year in Review. https://www.seia.org/research-resources/us-solar-market-insight-2012-year-review.

GTM Research, and SEIA. 2014. U.S. Solar Market Insight Report 2013 Year in Review. https://www.seia.org/research-resources/us-solar-market-insight-2013-year-review.

GTM Research, and SEIA. 2015. U.S. Solar Market Insight Report 2014 Year in Review. https://www.woodmac.com/reports/power-markets-u-s-solar-market-insight-2014-yearin-review-58128514.

GTM Research, and SEIA. 2016. U.S. Solar Market Insight Report 2015 Year in Review. https://www.seia.org/research-resources/solar-market-insight-2015-q4.

GTM Research, and SEIA. 2017. U.S. Solar Market Insight -- Full Report -- 2016 Year in Review. https://www.seia.org/research-resources/solar-market-insight-report-2016-yearreview.

GTM Research, and SEIA. 2018. U.S. Solar Market Insight 2017 Year in Review. https://www.seia.org/research-resources/solar-market-insight-report-2017-year-review.

Horowitz, Kelsey A. W., Ran Fu, and Michael Woodhouse. 2016. "An analysis of glass-glass CIGS manufacturing costs." Solar Energy Materials and Solar Cells 154:1-10. doi: https://doi.org/10.1016/j.solmat.2016.04.029.

Hutchins, Mark. 2018. The long read: Backsheets to the future https://www.pv-magazineindia.com/2018/10/01/the-long-read-backsheets-to-the-future/: PV Magazine.

IHS. 2018. Global Solar Intelligence Service. https://technology.ihs.com/Services/438743/global-solar-intelligence-service.

IMARC. 2018. Power Inverter Market: Global Industry Trends, Share, Size, Growth, Opportunity and Forecast 2018-2023. https://www.imarcgroup.com/prefeasibility-reportpower-inverter-manufacturing-plant

IndexBox. 2018. U.S. Flat Glass Market. Analysis And Forecast to 2025. https://www.indexbox.io/store/us-flat-glass-market-analysis-and-forecast-to2020/?utm source=abn.

International Energy Agency. 2018. World Energy Outlook 2018. https://www.oecdilibrary.org/content/publication/weo-2018-en.

ITRPV Working Group. 2018. International Technology Roadmap for Photovoltaic (ITRPV) 2017 Results. 
http://www.itrpv.net/.cm4all/uproc.php/0/ITRPV\%20Ninth\%20Edition\%202018_1.pdf?c $\mathrm{d} p=a \&=16224$ ec6558: SEMI, Berlin, Germany.

Jones-Albertus, Rebecca, Wesley Cole, Paul Denholm, David Feldman, Michael Woodhouse, and Robert Margolis. 2018. "Solar on the rise: How cost declines and grid integration shape solar's growth potential in the United States." MRS Energy \& Sustainability 5:E4. doi: https://doi.org/10.1557/mre.2018.4.

Jossi, Frank. 2018. Canadian company reboots northern Minnesota solar panel factory. https://energynews.us/2018/07/23/midwest/canadian-company-reboots-northernminnesota-solar-panel-factory/.

Kurtz, Sarah, John Wohlgemuth, Michael Kempe, Nick Bosco, Peter Hacke, Dirk Jordan, David C Miller, Timothy J Silverman, Nancy Phillips, and Thomas Earnest. 2013. Photovoltaic module qualification plus testing. https://www.nrel.gov/docs/fy14osti/60950.pdf: National Renewable Energy Laboratory (NREL), Golden, CO (United States).

Maycock, P., and T. Bradford. 2007. "PV Technology, Performance, and Cost, 2007 Update." Prometheus Institute for Sustainable Development and PV Energy Systems.

Michael, Jee Joe, and Iniyan Selvarasan. 2017. "Economic analysis and environmental impact of flat plate roof mounted solar energy systems." Solar Energy 142:159-170. doi: https://doi.org/10.1016/j.solener.2016.12.019.

Moskowitz, Scott. 2017. The Global PV Inverter and MLPE Landscape, H2 2017. https://www.woodmac.com/reports/power-markets-the-global-solar-pv-inverter-andmlpe-landscape-h2-2017-58118270: GreenTech Media.

Moskowitz, Scott. 2018. Global Solar PV Tracker Market Shares and Shipment Trends 2018. https://www.greentechmedia.com/research/report/global-solar-pv-tracker-market-sharesand-shipment-trends-2018\#gs.2pJ5CKA.

NASDAQ. 2018. "U.S. Raw Steel Output Up Y/Y, Capacity Remains Above 80\%." accessed February 27, 2019. https://www.nasdaq.com/article/us-raw-steel-output-up-yy-capacityremains-above- 80 -cm1065186.

National Public Radio. 2019. "How The U.S. Steel Industry Is Reacting To Trump's Aspiration For A Steel Border Wall." accessed February 27, 2019. https://www.npr.org/2019/01/08/683339691/how-the-u-s-steel-industry-is-reacting-totrumps-aspiration-for-a-steel-border-w.

NSG Group. 2018. "Glass and Solar Energy." accessed December 4, 2018. https://www.nsg.com/en/nsg/sustainability/glassandclimatechange/glassandsolarenergy.

Osborne, Mark. 2017. Seraphim Solar USA ramps module capacity and gains vendor approval from residential finance firms. https://www.pv-tech.org/news/seraphim-solar-usa-rampsmodule-capacity-and-gains-vendor-approval-from-res.

Osborne, Mark. 2018. LG Electronics establishing a 500MW solar module manufacturing plant in US. https://www.pv-tech.org/news/lg-electronics-establishing-a-500mw-solar-modulemanufacturing-plant-in-us.

Persistence Market Research. 2017. Global Market Study on Flat Glass: Automotive and Solar Applications Expected to Remain Lucrative Segments During 2017 - 2025. https://www.persistencemarketresearch.com/market-research/flat-glass-market.asp.

Pickerel, Kelly. 2016. Are backsheets ruining solar panels? https://www.solarpowerworldonline.com/2016/09/backsheets-ruining-solar-panels/: Solar Power World. 
Pickerel, Kelly. 2018a. First Solar will build second, 1.2-GW capacity module manufacturing facility in Ohio. https://www.solarpowerworldonline.com/2018/04/first-solar-will-buildsecond-1-2-gw-capacity-module-manufacturing-facility-in-ohio/.

Pickerel, Kelly. 2018b. Two brand-new manufacturing names want a piece of the Made in USA solar panel market. https:/www.solarpowerworldonline.com/2018/11/two-brand-newmanufacturing-names-want-a-piece-of-the-made-in-usa-solar-panel-market/.

Pickerel, Kelly. 2018c. What's happening with U.S. solar after four months of panel tariffs. https://www.solarpowerworldonline.com/2018/06/whats-happening-with-u-s-solar-afterfour-months-of-panel-tariffs/.

Pilkington. 2018. The Float Process. https://www.pilkington.com/en/global/about/education/thefloat-process/the-float-process.

Powell, Douglas M., Ran Fu, Kelsey Horowitz, Paul A. Basore, Michael Woodhouse, and Tonio Buonassisi. 2015. "The capital intensity of photovoltaics manufacturing: barrier to scale and opportunity for innovation." Energy \& Environmental Science 8 (12):3395-3408. doi: https://doi.org/10.1039/C5EE01509J.

Read, Richard. 2013. SolarWorld to lay off 100 in Hillsboro as Chinese manufacturers continue cutting prices. https://www.oregonlive.com/business/index.ssf/2013/07/solarworld to lay_off_100 in h.html.

Redlinger, Michael, Roderick G. Eggert, and Michael Woodhouse. 2016. "Present and Future Silver Cost Component in Crystalline Silicon PV Module Manufacturing." Photovoltaics International 31 (NREL/JA-6A20-65052). doi: https:/www.pv-tech.org/technicalpapers/the-present-and-future-silver-cost-component-in-crystalline-silicon-pv-modu.

Roselund, Christian. 2018. Panasonic to hire 80 workers at Tesla's US gigafactory. https://www.pv-magazine.com/2018/05/17/panasonic-to-hire-80-workers-at-teslas-usgigafactory/.

Roselund, Christian. 2019. Silfab says it will bring metal wrap through solar to the United States. PV Magazine: https://pv-magazine-usa.com/2019/03/08/silfab-say-it-will-bring-metalwrap-through-solar-to-the-united-states/.

Sandor, Debra, Sadie Fulton, Jill Engel-Cox, Corey Peck, and Steve Peterson. 2018. "System Dynamics of Polysilicon for Solar Photovoltaics: A Framework for Investigating the Energy Security of Renewable Energy Supply Chains." Sustainability 10 (1):160. doi: https://doi.org/10.3390/su10010160.

Shumkov, Ivan. 2016. SunEdison to dispose of silicon wafer factory, close polysilicon facility. https://renewablesnow.com/news/sunedison-to-dispose-of-silicon-wafer-factory-closepolysilicon-facility-513647/.

Silicon Materials Inc. 2018. "About Silicon Wafer Manufacturing." http://www.siliconmaterials.com/about-silicon-materials/.

Smith, Kevin, Preeti Sriram, and Robin Waters. 2017. Polyethylene Resins, Low-Density (LDPE) In Chemical Economics Handbook: IHS Markit.

Solar Energy Industries Association. 2018. Solar Industry Research Data. https://www.seia.org/solar-industry-research-data.

Solar Power World. 2019. "Global Inverter Manufacturing Locations ", accessed March 20, 2019. https://www.solarpowerworldonline.com/global-inverter-manufacturing-locations/. 
Spector, Julian. 2019. "Senators Propose Ban on Huawei Solar Inverters, Citing 'National Security Threat'." https://www.greentechmedia.com/articles/read/senators-propose-banon-huawei-solar-inverters-citing-national-security-thr\#gs.2ua2p8.

SPV Market Research. 2017. Photovoltaic Manufacturer Capacity, Shipments, Price \& Revenues 2016/2017. http://www.spvmarketresearch.com/.

SPV Market Research. 2018. Photovoltaic Manufacturer Capacity, Shipments, Price \& Revenues 2017/2018. http://www.spvmarketresearch.com/.

Sriram, Preeti, Leshan Hou, Mike Nash, and Julian Skibitzki. 2018. Vinyl Acetate. In Chemical Economics Handbook: IHS Markit.

Suresh, Bala. 2017. Acetylene - Consumption - United States : Calcium Carbide - Chemical Economics Handbook. IHS Markit.

Sylvia, Tim. 2019. SunPower officially producing P-Series at former SolarWorld factory in Oregon. PV Magazine: https://pv-magazine-usa.com/2019/02/07/sunpower-officiallyproducing-220-mw-p-series-at-former-solarworld-factory-in-oregon/.

Tanaka, Kanako, Toshihiro Inoue, Ryuji Matsuhashi, and Koichi Yamada. 2018. "Global value chain assessment based on retrospectively induced economic costs associated with technology application: A case study of photovoltaic power system in Japan." Journal of Cleaner Production 181:460-472. doi: https://doi.org/10.1016/j.jclepro.2018.01.184

The National Glass Association, and Glass Magazine. 2018. "The World of Glass Map." https://worldofglassmap.com/.

TheMarketReports. 2018. Global EVA Resin Market Research Report 2018. https://www.themarketreports.com/report/global-eva-resin-market-research-report-201896976378.

U.S. Customs and Border Protection. 1997. b85473: The tariff classification of polyvinyl fluoride film. https://rulings.cbp.gov/ruling/B85473.

U.S. Customs and Border Protection. 2010. N115543: The tariff classification of ethylene vinyl acetate film from China. https://rulings.cbp.gov/ruling/N115543.

U.S. Customs and Border Protection. 2018a. QB 18-111 2018 Solar Cell/Modules. https://www.cbp.gov/trade/quota/bulletin/qb-18-111-2018-solar-cellmodules.

U.S. Customs and Border Protection. 2018b. Section 232 Tariffs on Aluminum and Steel. https://www.cbp.gov/trade/programs-administration/entry-summary/232-tariffsaluminum-and-steel.

U.S. Customs and Border Protection. 2018c. Section 301 Trade Remedies to be Assessed on Certain Products from China. https://www.cbp.gov/trade/programs-administration/entrysummary/section-301-trade-remedies.

U.S. Energy Information Administration. 2017. 2017 Annual Solar Photovoltaic Module Shipments Report. https://www.eia.gov/renewable/annual/solar_photo/pdf/pv full.pdf.

U.S. Energy Information Administration. 2018. FAQ - What is U.S. electricity generation by energy source? https://www.eia.gov/tools/faqs/faq.php?id=427\&t=3.

U.S. Geological Survey. 1998. Mineral commodity summaries 1998. In Mineral Commodity Summaries. Reston, VA: https://www.usgs.gov/centers/nmic/mineral-commoditysummaries.

U.S. Geological Survey. 2003. Mineral commodity summaries 2003. In Mineral Commodity Summaries. Reston, VA: https://www.usgs.gov/centers/nmic/mineral-commoditysummaries. 
U.S. Geological Survey. 2008. Mineral commodity summaries 2008. In Mineral Commodity Summaries. Reston, VA: https://www.usgs.gov/centers/nmic/mineral-commoditysummaries.

U.S. Geological Survey. 2013. Mineral commodity summaries 2013. In Mineral Commodity Summaries. Reston, VA: https://www.usgs.gov/centers/nmic/mineral-commoditysummaries.

U.S. Geological Survey. 2017. Mineral commodity summaries 2017. In Mineral Commodity Summaries. Reston, VA: https://www.usgs.gov/centers/nmic/mineral-commoditysummaries.

U.S. Geological Survey. 2018. Mineral commodity summaries 2018. In Mineral Commodity Summaries. Reston, VA: https://www.usgs.gov/centers/nmic/mineral-commoditysummaries.

U.S. International Trade Administration. 2012. Crystalline Silicon Photovoltaic Cells, Whether or Not Assembled Into Modules, From the People's Republic of China: Amended Final Determination of Sales at Less Than Fair Value, and Antidumping Duty Order. In 201229668, edited by U.S. International Trade Administration. https://www.federalregister.gov/documents/2012/12/07/2012-29668/crystalline-siliconphotovoltaic-cells-whether-or-not-assembled-into-modules-from-the-peoples.

U.S. International Trade Administration. 2015. Certain Crystalline Silicon Photovoltaic Products From the People's Republic of China: Antidumping Duty Order; and Amended Final Affirmative Countervailing Duty Determination and Countervailing Duty Order. In 201503183, edited by U.S. International Trade Administration. https://www.federalregister.gov/documents/2015/02/18/2015-03183/certain-crystallinesilicon-photovoltaic-products-from-the-peoples-republic-of-china-antidumping.

USITC. 2017. U.S. International Trade Commission Interactive Trade DataWeb. https://dataweb.usitc.gov/.

Weaver, John. 2018. Hurricane Maria moves Solartech Universal's expansion to South Florida. https://pv-magazine-usa.com/2018/05/21/hurricane-maria-moves-solartech-universalexpansion-to-continental-us/.

Weinshenker, Beryl. 2017. U.S. PV Racking 2017: Landscape, Pricing and Forecasts. https://www.greentechmedia.com/research/report/us-pv-racking-2017-landscape-pricingand-forecasts\#gs.Q1R_xT0.

Wesoff, Eric. 2017. Siva Power Lands \$25M to Chase Giga-Scale Domestic Thin-Film Solar Production. https://www.greentechmedia.com/articles/read/siva-power-lands-25m-tochase-giga-scale-domestic-thin-film-solar\#gs.t1739y0.

Wood, Laura. 2016. Global Flat Glass Market. http://www.marketwired.com/pressrelease/global-flat-glass-market-2112397.htm.

Wood Mackenzie. 2018. Power \& Renewables Energy Research: Global Solar Markets Service. https://www.woodmac.com/research/products/power-and-renewables/solar-pv-marketsservice/.

Woodhouse, M., A. Goodrich, M. Redlinger, M. Lokanc, and R. Eggert. 2013. The Present, MidTerm, and Long-Term Supply Curves for Tellurium; and Updates in the Results from NREL's CdTe PV Module Manufacturing Cost Model (Presentation). https://www.osti.gov/servlets/purl/1095395.

Woodhouse, Michael, Brittany Smith, Ashwin Ramdas, and Robert Margolis. 2019. Crystalline Silicon Photovoltaic Module Manufacturing Costs and Sustainable Pricing: 1H 2018 
Benchmark and Cost Reduction Roadmap. National Renewable Energy Laboratory: https://www.nrel.gov/docs/fy19osti/72134.pdf.

Worstall, Tim. 2016. "It's Not China Or Trade That Killed The Steel Jobs But Recycling." https://www.forbes.com/sites/timworstall/2016/08/05/its-not-china-or-trade-that-killedthe-steel-jobs-but-recycling/\#363fabd84d66.

Yole Développement. 2016. "Inverter Technology Trends and Market Expectations." accessed August 22, 2018. https://www.i-micronews.com/report/product/inverter-technologytrends-and-marketexpectations.html? utm_source=PR\&utm_medium=email\&utm_campaign=Inverter_Chin eseMarket YOLE June2016.

Zipp, Kathie. 2018. U.S. solar inverter market value increases, while global market value declines. In Solar Power World. https://www.solarpowerworldonline.com/2018/04/u-ssolar-inverter-market-value-increases-while-global-market-value-declines/. 


\section{Appendix}

\section{A.1 U.S. PV Manufacturing Capacity}

Table 16. U.S. PV Manufacturing Capacity in Q1 2017 and Announcements during 2017-2019

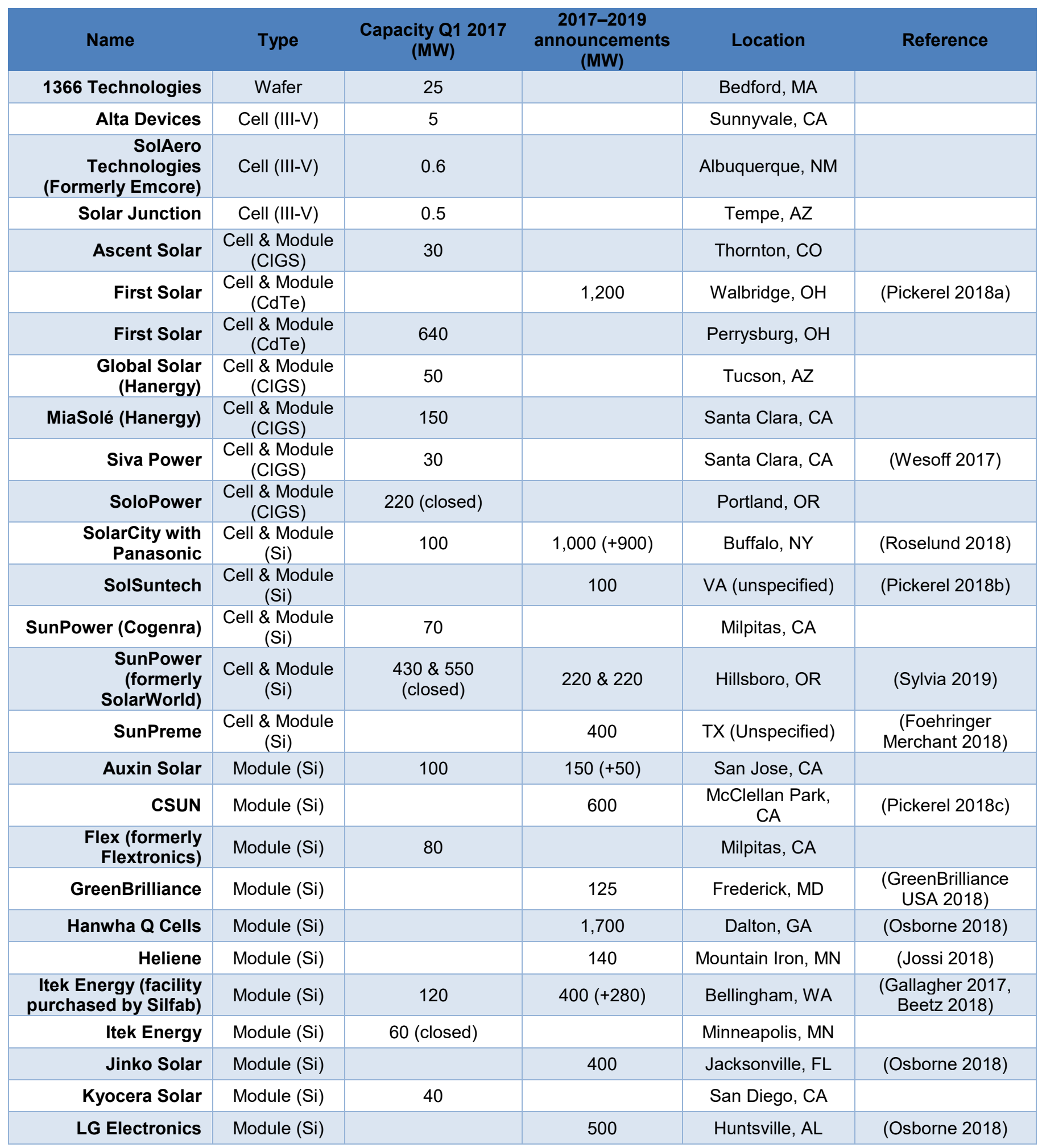




\begin{tabular}{|c|c|c|c|c|c|}
\hline Mission Solar & Module (Si) & 200 & $400(+200)$ & San Antonio, TX & (Osborne 2018) \\
\hline Prism Solar & Module (Si) & 60 & & Highland, NY & \\
\hline $\begin{array}{l}\text { Seraphim Solar USA } \\
\text { Manufacturing, Inc. }\end{array}$ & Module (Si) & 160 & $500(+340)$ & Jackson, MS & (Osborne 2017) \\
\hline $\begin{array}{r}\text { Solar Electric } \\
\text { America }\end{array}$ & Module (Si) & & 60 & Richmond, VA & \\
\hline Solaria & Module (Si) & 40 & & Fremont, CA & \\
\hline SolarTech Universal & Module (Si) & 80 & & Riviera Beach, FL & \\
\hline SolarTech Universal & Module (Si) & & 180 & FL (unspecified) & (Weaver 2018) \\
\hline Solartecmx LLC & Module (Si) & 30 & & Houston, TX & \\
\hline Unicor & Module (Si) & 50 (closed) & & Sheridan, OR & \\
\hline \multirow[t]{3}{*}{ TOTALS } & & $\begin{array}{c}\text { Existing from } \\
2017 \text { Q1 (MW) } \\
\text { (excluding } \\
\text { subsequently } \\
\text { closed capacity) }\end{array}$ & $\begin{array}{c}\text { Announced } \\
\text { Additions (MW) }\end{array}$ & TOTAL (MW) & \\
\hline & $\begin{array}{l}\text { Silicon Cell } \\
\text { Capacity }\end{array}$ & 170 & 1,620 & 1,790 & \\
\hline & $\begin{array}{l}\text { Module } \\
\text { Capacity } \\
\text { (Silicon and } \\
\text { Thin Film) }\end{array}$ & 2,220 & 7,395 & 9,615 & \\
\hline
\end{tabular}




\section{A.2 Data for PV System Cost and Mass Breakdown}

Table 17. Breakdown of 295-W PV Module Cost and Mass (260-W Module in Parentheses)

\begin{tabular}{|c|c|c|}
\hline Module Component & Cost & Mass $(\mathrm{kg})$ \\
\hline Silicon cells (metallized) & $\$ 55(\$ 48)$ & $0.8(0.7)$ \\
\hline Glass & $\$ 7(\$ 6)$ & $14.6(12.9)$ \\
\hline Aluminum frame & $\$ 6(\$ 5)$ & $1.8(1.7)$ \\
\hline EVA (encapsulant) & $\$ 5(\$ 4)$ & $1.6(1.4)$ \\
\hline Backsheet & $\$ 4(\$ 3)$ & $0.3(0.3)$ \\
\hline Tabbing/stringing & $\$ 4(\$ 3)$ & $0.2(0.2)$ \\
\hline Junction box & $\$ 4(\$ 3)$ & $0.1(0.1)$ \\
\hline Non-material costs* & $\$ 18$ & -- \\
\hline Total & $\$ 103(\$ 91)$ & $19.4(17.3)$ \\
\hline
\end{tabular}

*Non-material costs include module-assembly cash costs, depreciation, research and development, and selling, general, and administrative expenses.

Table 18. Cost and Mass Breakdown of 100-MW Utility-Scale PV System: 295-W Modules and Steel Racking

\begin{tabular}{|r|cc|}
\multicolumn{1}{|c}{ System Component } & $\begin{array}{c}\text { Cost } \\
\text { per Module }\end{array}$ & $\begin{array}{c}\text { Mass }(\mathbf{k g}) \\
\text { per Module }\end{array}$ \\
\hline Steel racking-single-axis tracker (fixed tilt) & $\$ 45(\$ 30)$ & $28.3(27.1)$ \\
\hline Inverter & $\$ 18$ & 0.8 \\
\hline Conduit & $\$ 5$ & 2.1 \\
\hline Transformer & $\$ 4$ & 1 \\
\hline Electrical BOS & $\$ 21$ & 0.9 \\
\hline Module & $\$ 103$ & 19.4 \\
\hline Total*-single-axis tracker (fixed tilt) & $\$ 196(\$ 181)$ & $\mathbf{5 2 . 5}(\mathbf{5 1 . 3 )}$ \\
\hline
\end{tabular}

${ }^{*}$ The following utility system costs are not included: 1) installation labor and equipment, 2) EPC overhead, 3) sales tax, 4) land acquisition, 5) permitting, 6) interconnection fee, 7) transmission lines, 8) developer overhead, 9) contingency, and 10) net profit.

Table 19. Cost and Mass Breakdown of 200-kW Ground-Mount Commercial PV System: 295-W Modules and Steel Racking

\begin{tabular}{|r|c|c|}
\multicolumn{1}{|c}{ System Component } & $\begin{array}{c}\text { Cost } \\
\text { per Module }\end{array}$ & $\begin{array}{c}\text { Mass }(\mathbf{k g}) \\
\text { per Module }\end{array}$ \\
\hline Steel racking—single-axis tracker (fixed tilt) & $\$ 60(\$ 44)$ & $28.3(27.1)$ \\
\hline Inverter & $\$ 30$ & 0.8 \\
\hline Conduit & $\$ 5$ & 2 \\
\hline Transformer & $\$ 4$ & 1 \\
\hline Electrical BOS & $\$ 35$ & 0.3 \\
\hline Module & $\$ 103$ & 19.4 \\
\hline Total*-single-axis tracker (fixed tilt) & $\$ 237(\$ 221)$ & $\mathbf{5 1 . 8}(\mathbf{5 0 . 6})$ \\
\hline
\end{tabular}

${ }^{*}$ The following commercial system costs are not included: 1) installation labor and equipment, 2) EPC overhead, 3) sales tax, 4) permitting, inspection, and interconnection fees, 5) developer overhead, 6) contingency, and 7) net profit. 
Table 20. Cost and Mass Breakdown of 200-kW Rooftop Commercial PV System: 295-W Modules and Aluminum Racking

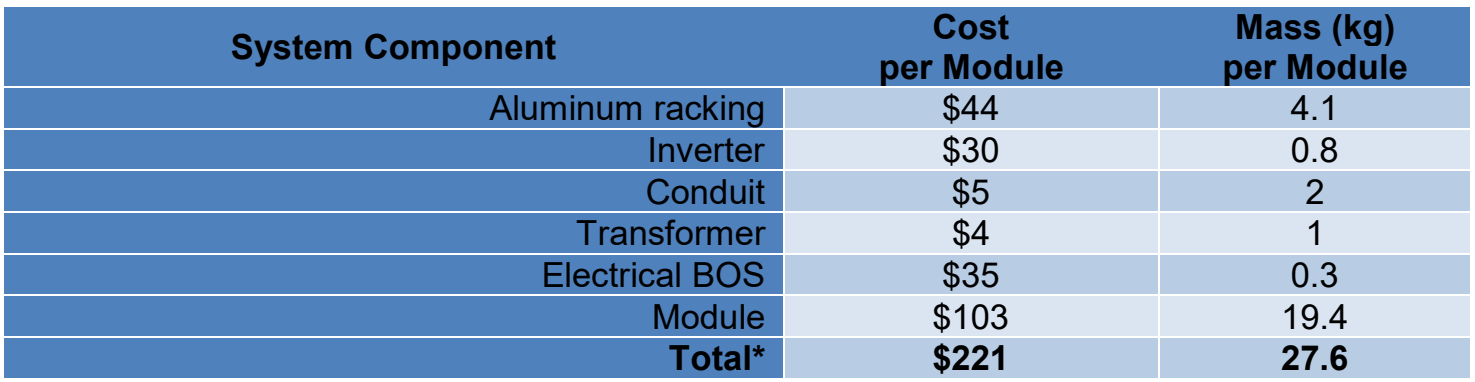

*The following commercial system costs are not included: 1) installation labor and equipment, 2) EPC overhead, 3) sales tax, 4) permitting, inspection, and interconnection fees, 5) developer overhead, 6) contingency, and 7) net profit.

Table 21. Cost and Mass Breakdown of 5.7-kW Residential PV System: 260-W Modules and Aluminum Racking

\begin{tabular}{|r|c|c|}
\hline \multicolumn{1}{|c|}{ System Component } & $\begin{array}{c}\text { Cost } \\
\text { per Module }\end{array}$ & $\begin{array}{c}\text { Mass }(\mathrm{kg}) \\
\text { per Module }\end{array}$ \\
\hline Aluminum racking & $\$ 27$ & 3.6 \\
\hline weighted average (Fu et al. 2017) & $\$ 50$ & 0.8 \\
\hline Conduit & $\$ 5$ & 2 \\
\hline Electrical BOS & $\$ 53$ & 1 \\
\hline Module & $\$ 91$ & 17.3 \\
\hline Total* & $\$ 231$ & $\mathbf{2 5}$
\end{tabular}

*The following residential system costs are not included: 1) supply chain costs, 2) sales tax, 3) installation labor, 4) permitting, inspection, and interconnection, 5) customer acquisition costs, 6) overhead, and 7) net profit. 